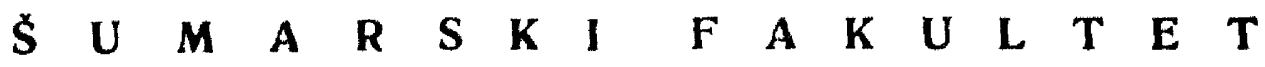

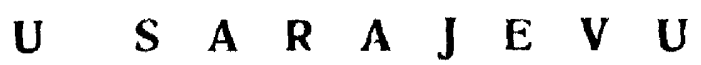

Posebna izdanja: br. 16

STEFANOVIC V., BEUS V., BOZALO $\mathrm{G}_{\text {., }}$

PAVLIC J., VUKOREP I.

\title{
TIPOVI ŠUMA SMRČE I BIJELOG BORA, JELE I SMRČE I SMRČE U BOSHI
}

MISCHWALDTYPEN DER FICHTE UND FÖHRE, DER TANHE UND FICHTE UND FICHTENWÄLDER IN BOSHIEN 


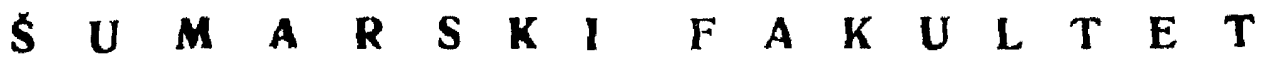

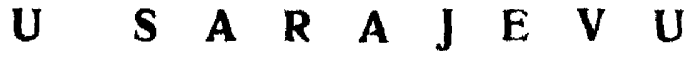

EXIIIBRIS

Posebna izdanja: br. 16

STEFANOVIC V., BEUS V., BOZALO G.,

PAVIJC J., VUKOREP I.

\section{TIPOVI ŠUMA SMRĞE I BIJELOG BORA, JELE I SMRČE I SMRČE U BOSWI}

\section{MISCHWALDTYPEN DER FICHTE UND FÖHRE,
TANME UND FICHTE UND FICHTENWÄLDER IN BOSNIEN}

Drugn Strjaunioin a tunk pasinge

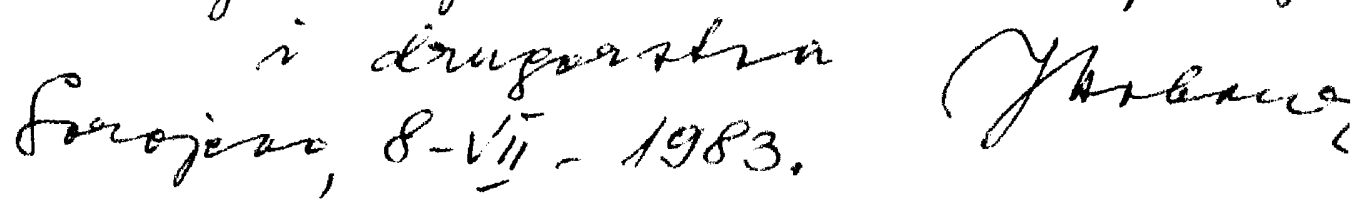




$$
\begin{aligned}
& \text { Posebna izaanja br. } 16 \\
& \text { Ureduje: }
\end{aligned}
$$

Komisija za izdavačku djelatnost Sumarskog fakulteta u Sarajevu

Prof. dr Ostoja Stojanović, predsjeçnik

Prof. dr Vitomir Stefanovic, urednit:

Prof. dr Midhat Ušcuplić

Prof. dr Ivan Vukorep

Asistent Dušan Miodrag, wici, sekretur

$$
\text { Recenzenti: }
$$

Prof. dr Branislav Jovanović, Sumarski fakultet, Beograd Prof. dr Petar Drinic, Sumarski fakultet, Sarajevo Prof. dr Nikola Jović, Sumarski fakultet, Beograd

\author{
Le k t or \\ Jasminka Melkić, pr,fesor
}

Tiraž: 500 primjeraka

Uredništvo i administracija: Sumarski fakultet, Sarajevo Zagrebačka 20

Telefon: (071) 611-033

Stampa: Radniěki univerzitet $\nsim$ Duro Dakovič u Sarajevu Za stampariju: Palek? Momir 
$S A D R Z A J$

strafia

I IVVOD $\ldots \ldots \ldots \ldots . \ldots \ldots$

1. Zadatak i cilj istrazivanja - .............. 6

2. Metod rada _........................... 6

II OSNOVNE KARAKTERISTIKE SUMA SMRCE I BIJHLOG BORA, JELC I

SMRCE I SMRCE U BiH … . . . . . . . . . . .

A. Vegetacijske karakteristike _ . . . . . . . . .

B. Karakteristike zemijista - . . . . . . . . . 13

C. Stanje sumskog fonda

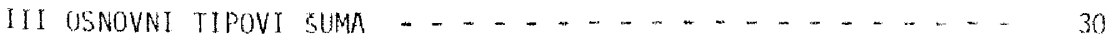

IV PROLZVODNI TIPOVI S̈UMA _....................... 81

Zusammenfassung _ . . . . . . . . . . . . 112

IITERATURA _..................... 115 



\section{$P R E \cap 0 \vee O R$}

Tipološka klasifikacija suma smrce i bijelog bora, jele i smr. ce je nastavak radova na ekološko-proizvodnoj klasifikaciji šma u Bosn i Hercegovini prema koncepcijama izloženim u jednom od prvih radova ine vrste kod nas ( $c$ i $r$ i $c$ et al., 1971).

Rezultati ovih istraživanja namijenjeni su, kao i dosadasnji, prije svega, sumarskoj raksi i racionalnijem knristenju sunskin potin. cijala Bosne i Hercegovine.

Rad predstavlja sintezu fitocenoloških, pedološkin, sumiskomiklioratiunih i taksacionih istraživanja. Poglavlje o vegetaciji obradili sU STEFANOVIC V. i BEUS V., o zemljištima VUKOREP $I$., o taksacionim elementima PAVLIC J. i BOZALO G., a ostala poglavija u radu autori su otradili zajedno. U radu su korišteni, pored podataka naših terenskih istraživanja, i podaci iz prikupljenog materijala Inventure šuma fa velikim površinama u Bosni i Hercegovini (M a $t$ i ć et al., 1971).

Izradu rada finansirali su Republička zajednica za naućni rad i Sumarski fakultet u Sarajevu, na cemu im izražavamo zahvalnost. Takodje se zahvaljujemo i 00uR "SiTva" institutu za istrazivanje i projektovanje u sumarstvu na ustupljenom materijalu terenskin snimarija Inventure šuma, koji smo koristili u ovom radu. 


\section{$I \cup \vee O D$ \\ 1. ZADATAK I CILJ ISTRAZZIVANJAA}

Za racionalno gazdovanje šumana smrče i bijelog bora, jele i smrče $i$ smrče u Bosni i Hercegovini nužna je njihova ekološko-proizvodna klasifikacija u kojoj bi njihove pedološke, fitocenološke i taksacione karakteristike bile medjusobno korelativno povezane. Dabi se ostvario ovaj cilj izvršena su sinhronizovana ekološko-proizvodna istraživanja i definisanje osnovnih i proizvadnih tipova ovih šuma. Naučno-definisani tipovi šuma treba da budu polazna osnova za dugoročna planiraija proizvodnje u ovim šulama. Definisani tipovi šuma u ovom radu treba da posluže i kao modeli za njihovo identifikovanje pri izradi -karti tipova šuma $u$ novim sunsko-privrednim osnovama.

\section{METOD RADA}

Metod rada za tipološku klasifikaciju šuma smrc̀e i bijelog bora, jele mijenjenim u tipološkim klasifikacijama suma, kaji baziraju na razradjenom metodu klasifikacije bukovih suma i mješovitih šuma bukve, jele i smrce (ciric et al., 1971).

Klasifikacija je dvofazna. U prvoj fazi se izdvajaju jedinice priblizno jedrakin ekolosko-vegetacijskih obiljeżja, a u drugoj fazi vrši se formiranje proizvodnin tipova suma.

Snimanje vegetacijskin, pedoloskih i taksacionih podataka obavljeno je na vecem broju ploha (primjernih krugova) (od 11 do 56) za svaki osnovni tip šume. Ova snimanja, kao i sinteza podataka, izvršena je na usnovama reprezentativnog matematsko-statističkog metoda, koji je primijenjen u Inventuri šuma na velikim površinama ( $M$ a $t i c$ et a1., 1971).

Kod snimanja na terenu u opisu opštih uslova, registruju se: lokalitet, nadmorska visina, ekspozicija, inklinacija $i$ reljef.

Pedoloska snimanja obuhvataju opis profila na svakoj plohi i ocjenu fizičko-hemijskih svojstava zemljišta. 
Vegetacijska sninianja obuhvataju izradu fitocenoloških snimaka na svakoj plohi po metodi $B r$ a $u n$.. B I a n q u e t a ucjljuuturdjivanja karakteristicnog skupa vrsta za odredjene tipove šuna.

Taksaciona snimanja obuhvataju prikup!janje porataka na svakoj plohi, na osnovu kojih su uturdjeni: stepen sklopa, omjer smjese, veličina zalihe, debljinska struktura, kvalitet zalihe, godišnji-tekući - zapremirıski prirast, stanje podmlatka.

Na osnovi analize potencijala staništa, osnovni tipovi šumakoji su imali približno iste ekološke karakteristike $j$ proizvodne sposobnosti objedinjeni su u jedan proızodni tip. Za svaki proizvodni tip utvrdjeni su: moguci proizvodni cilj (izbor vrsta drveča i način gazdovanja), model normalnog stanja $i$ prognoza produktivnosti, ograničenja $i$ opasnosti ko.je se mogu javiti pri datom načinu iskorǰ̌cavanja.

\section{OSNOVNE KARAKTERISTIKESUMA $S M R C E I B I J E L O G$ BORA, JELE I $S M R C E I S M R C E U B I H$}

\section{A. VEGETACIJSKE KARAKTERISTIKE}

Istorijski faktori, prirodni uslovi, prvenstveno klimatski, uslovili su sasvin odredjene zakonitosti u rasprostranjenju ovih suma. 5 obzirom da su smrča i bijeli bor, borealni flomi elementi, a jela srednjoevropski, očekivati je da su zajednice kaje one obrazuju rasprostranjene u unutrašnjem kontinentainom dijelu Dinarskih planina. Tu postoje ipak izvjesne razlike izmedju bijelog bora i smrče, s jedne, i jele, s druge strane. Prve dvije vrste obrazuju areal u središnjem dijeludinarida, sa granicom prema submediteranu na liniji Glamocko polje - Vran planina - Bjelašnica - Zelengora, a na sjeveru do oboda planina Panonskog bazena. Jela, pak, zalazi dublje u submediteransko područje (Velež, Nevesinjska Crna gora, Gatačka Bjelašnica, Prenj, Cursnica itd.), te kao poseban kseromorfni fenotip obrazuje specifične zajednice kserotermofilnih osobina (F u k a $r \in k, P ., 1970)$.

Poredjenjem areala ove vrste drveca sa arealom simrče ( $F$ u $k$ a$r$ ek, P., 1970) uočava se njihova podudarnost rasprostranjenosti u cen- 
tralnom dijelu Dinarida, ali isto tako i eskiavo areala jele usubmediteranskim visokim planinama Hercegovine i na rubu Panonskog bazena, no knzari i Mejevici. U tom pogledu bijeli bor se pribizava vise jeli, jer kako su pokazala istraživanja njegovog areala $(S$ t e $f$ a $n$ o $v i$ i., 1958), ova vrsta prehvata, na peridotitu i serpentinitu sjeverne i sjom veroistične Bosne, ulazi u područje sa izraženijim panonskim klimatskin uticajima. Pojava smrče u ovom podruçiu vezarid je iskl.jucivo za peridotitsko-serpentinitske stijenc (B e us, V., 1980), ali za razliku od bijelog bora ima užu rasprostranjemost.

Na osnovu rezultata cenoloških istraživanja zajednica bijelou bora $i$ smrče u Basni (s t e f a no $v i c, \quad v ., 1960,1964,1969,1970$ ) $i$ smrc̈e (Fuk a rek, P., 1969; s t e fa novic, V., 1967) poznate su ne samo osnovne zakonitosti njihovog rasprostranjenja, rego i ijihove osnovne cenološke $i$ sumskouzgojne karakteristike.

Za razliku od nekih primarnih fitocenoza smrce mrazisnog tipd u montanoj i subalpinskoj zoni (Igman, cincar, Vitorog. Vranica,jahorina i dr.), fitocenoze bijelog bora i surče, odnosno jele i smrče, koje su poslužile kau osnova za definisanje osnovnih i proizvodnih tipova suma u ovoj studiji predstavljaju sekundarne sume, odnosno prelazne stadije unutar klimaregionalne zajednice bukve i jele (Abieli-kagetum) središnjeg dinarskoq područja.

\section{SUMA SMRČE I BIJELOG BORA (Piceo-Pinetum sens. lat.)}

Areal im je disjunktan unutar pojasa klimaregionalne zajednjce bukve i jele (Abieti-fagetum illyricum). Znaçajniji kompleksi nalaze se u zapadnoj Bosni (Kupres-Glamoč), zatim u srednjoj i istocnoj Bosni (sire područje oko Varesá i Romanijske visoravni). Uvijek su na platoima - zaravnima ili na osunčanim položajima.

Floristicki sastav je neposredno uslovijen stepenom razvoja sastojina (inicijalna, optimalna, terminalna faza), pa su najprije zastupljeni heliofilni elementi, da bi kasnije preovladavali polusciofilni elementi. Uporedo sa povecanjem sklopa sastojina dolazi do promjena uzemijištu, humusnom horizontu, što prate acidofilne vrste u prizemnom sloju

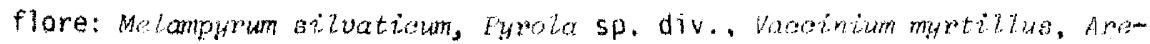




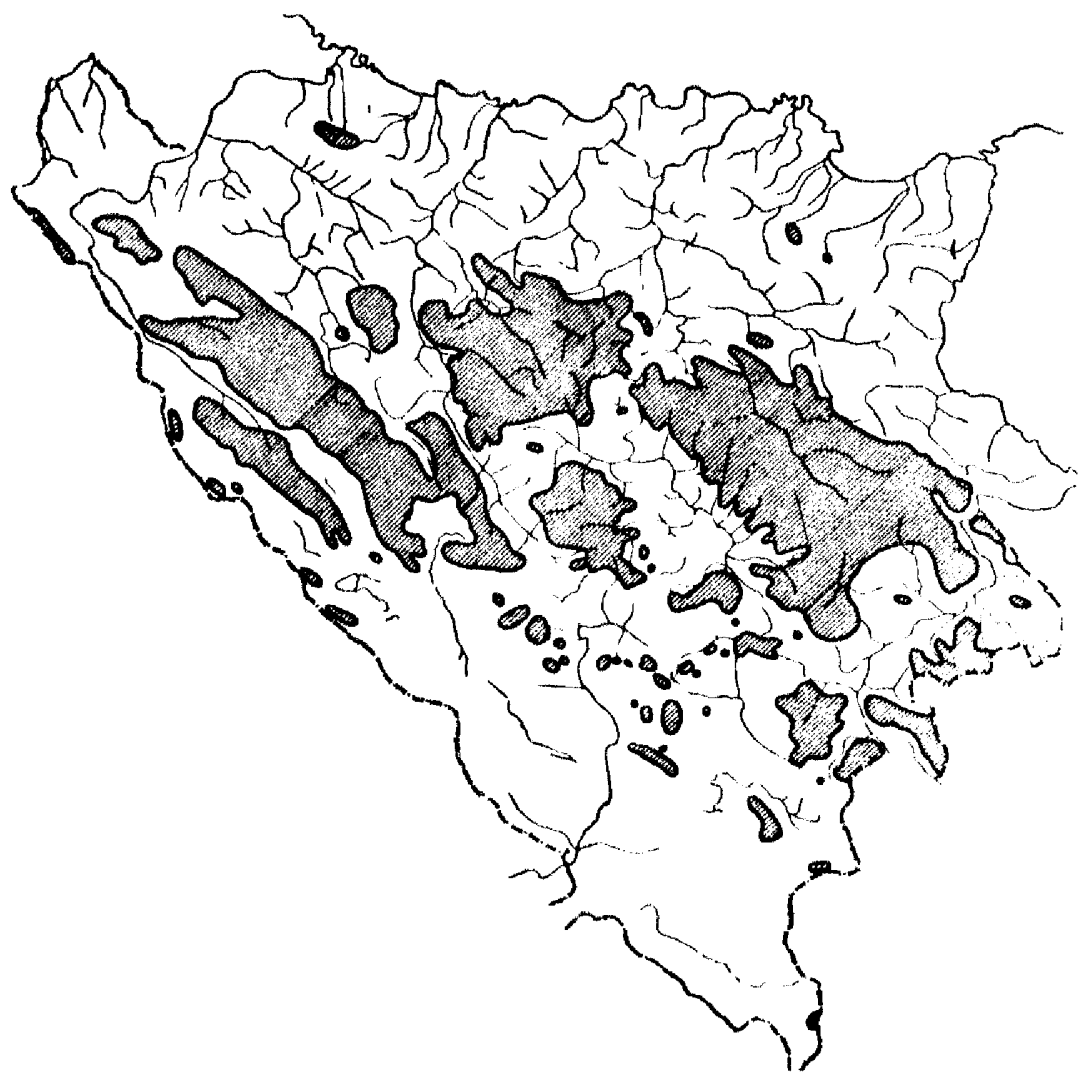

Karta 1: Rasprostranjenost jele (AR: atha Mil) u Bosni i Hercegovini

(prema P. Fukareku, 1970.) 


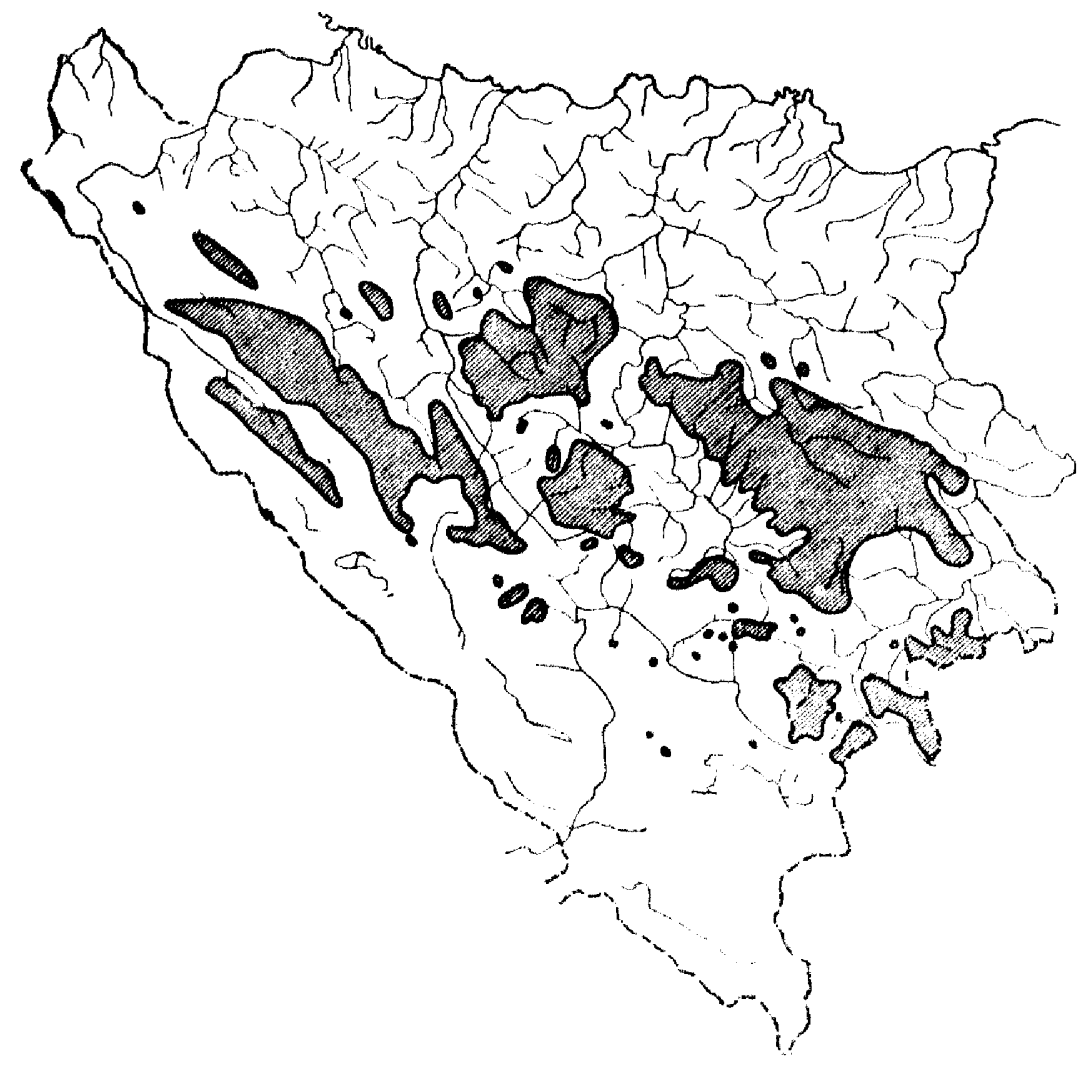

Karta 2: Rasprostranjenost smrče (Picea exceloa Link.) u Bosni i Hercegovini (prema P. Fukareku, 1970.) 
monia agrymonioides, te mahovine iz rodova Polytrichum, Dicranum, Bylow comium i drugih. Medjutim, zastupljeni su i neki elementi iz sveze fagion-a: Daphne mezereum, Lonicera xylosteum, L. alpigena. Ovi ukazuju na tendenciju razvoja ka klimaregionalnoj sumi bukve i jele (Abieti-Fagetum ilizurioum).

Suma je sekundarnog karaktera, te su njene faze razvoja obuhvacene unutar analiziranih tipova suma $\mathbf{i}$ okarakterisane ekološko-proizvednim osobinama.

\section{JUMA JELE I SMRCE (Abieti-piceetum sens. lat.)}

Imaju široku rasprostranjenost, počev od Grmeča na sjeverozapadu do Maglica j visoravni Meštrovca na jugoistoku (posebno na podrucju Kupresa, Vranice, Vlašica, Zvijezde, Romanije, Jahorine, te na jugoistoku Bosne u podruçju Celebica i Meštrovca). Zahvataju čitavo unutrašnje područje Dinarida unutar klimaregionalne zajednice bukve i jele (Abieti-Fagetum), gdje predstavijaju prelazne stadije vegetacije.

Odlikuju se mezofilnim stanišnim uslovima unutar klime sa planinskim obilježjima. Zastupljene su dvije serije zajednica: prva, na zemljištima bogatim, i druga, na zemljištima siromašnim bazama. Iako medju njima postoje razlike u florističkom sastavu kao odraz aciditeta zem]jišta, u drugom slučaju, vǐ̌e dolaze do izražaja acidofilni elementi, prvenstveno veca zastupljenost mahovina. Ove razlike cesto se umanjuju s obzirom na dejstvo bioloske akumulacije organskih ostataka i njihov uticaj na kvalitet i svojstva humusnog sloja zemijista, narocito u slučajevima kada je u područjima izgradjenim od krečnjaka čšca pojava interkalacija rožnjaka (Romanijska visoravan, Sjemeč planina), gdje je redovna pojava distričnog kambisola.

Zavisno od stepena razvoja, sklopa i obrasta,u inicijalnimstadijima mogu biti zastupljeni, pored smrce $i$ jele $i$ : bijeli bor, breza, jasika, iva, jarebika. Ostaci ovih heliofilnih vrsta drveća, sa pojedinačnim i grupimičnim javljanjem u sastojinama jele $i$ smrče odražavaju nekad terminalnu fazu zajednice bijelog bora i smrče (Picen-pinetumillyricum), koja je cinila jedan stadij ili kariku u ukupnom ciklusu razvoja vegetacije od požara do zatvaranja ovog ciklusa, tj. formiranja klimaregionalne sume bukve i jele. 


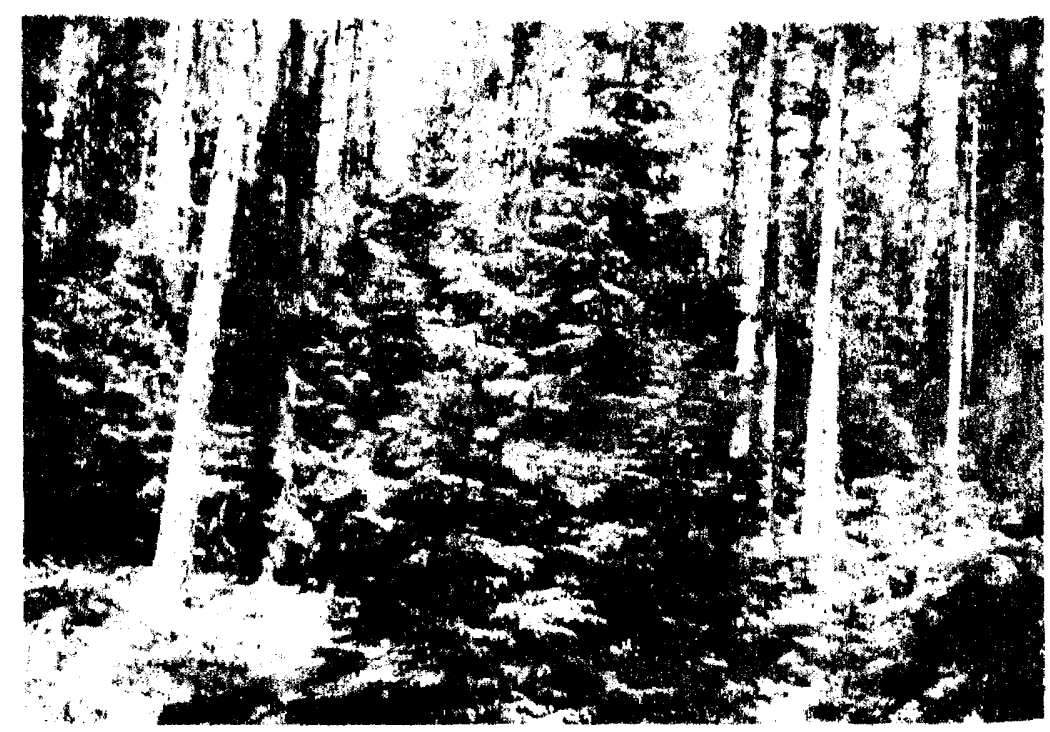

51. 1: Suma bijelog bora i smrce (Pioeo-pinetum) Predjeo Mescema na Romaniji

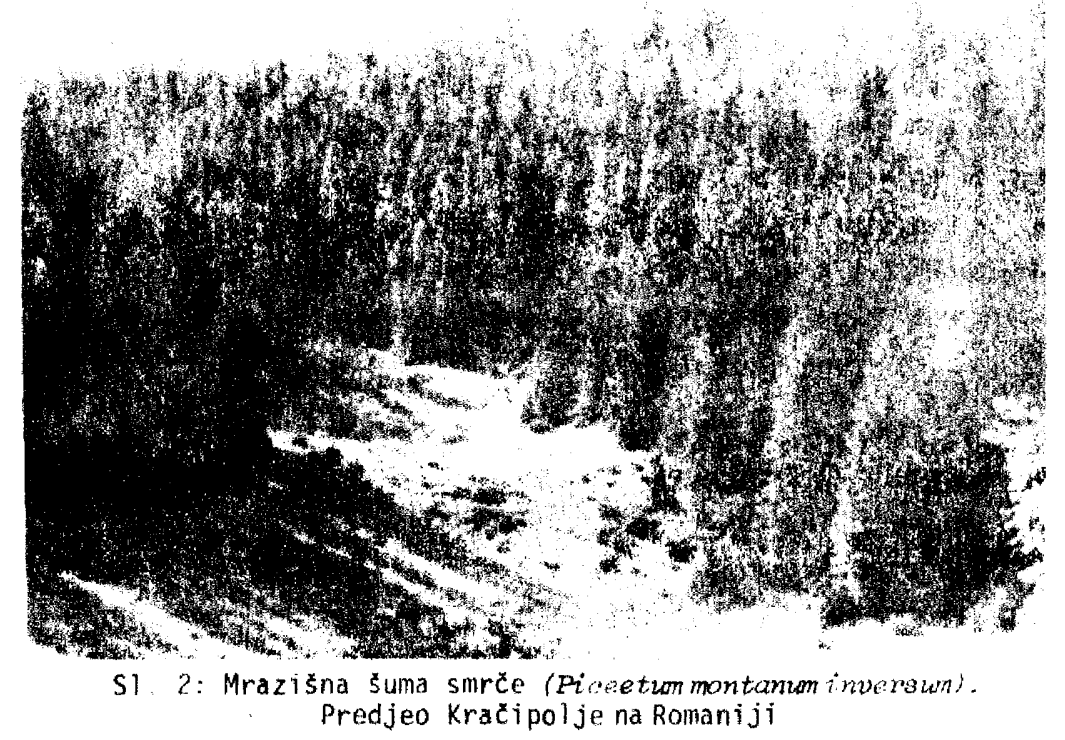


kao visoko proizvodre sume one se diterenciraju w srokom intervalu, sto ifustruju definisani osnovni i proizvodni tipovi suma.

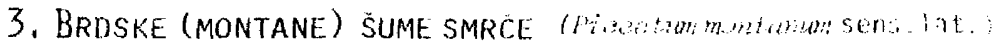

U središnjim Dinaridima javijaju se kao primarne zajednicemra-

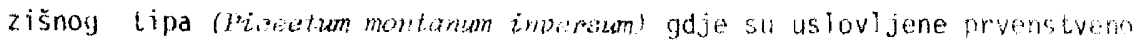
inverzijama temperature (npr. Igman, Vukovsko polje) ili edafsti aktor tome posebno doprinosi, kad su u pitanju podzoli ili pseudogiej lavije... da-Nisici). One mogu biti $j$ sekundarnog karaktera unutar pojasa bukve

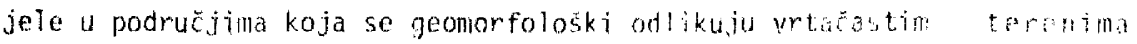
(Kračipolje, Džimrije na Romanifi planini), gdje je sa unistavanjem sume bukve i jele sa smréom došlo do pojaçanog uticaja mrazista.

U svin navedenim slučajevina one su veoma ogranicenog rasprostranjenja $i$ disjunktnog su areala, a podrucja se od likuju hladnom kl inom $i$ dužim zadržavanjem snježnog pokrivača. ledna od edafskihkarakteristika ovih šuma je specifična pojava morenskih i soliflukcionih nanosa nakojima se obrazuju preteino genetski madja cemijista. Rasprostranjent su iglavnom izmedju 1000 i 1300 madmorste visine.

Preteżno su monotipskog karaktera, pa osim smrceunjima je primijesana jarebika (Gorbus cucuparia): u prizemnom sioju karakteristicni

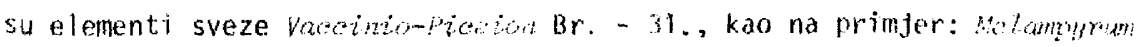

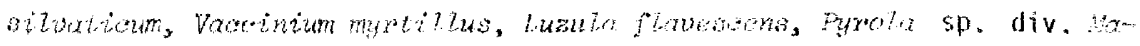

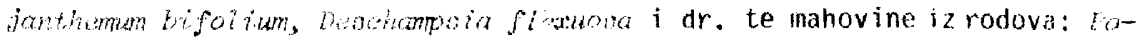

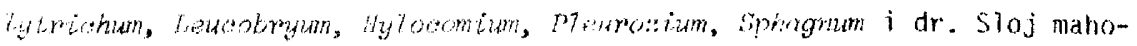
vina je naroçito izražen $u$ štumama na kiselim silikatnim nodlogana, gdje na primjer na podzolu izgradjuju "tepihe" debljine i preko deset centine.tara.

Pobrojane i druge osobine analiziraju se udefinisanim osnownin i proizvodnim tipovìna šuma.

\section{B. KARAKTERISTIKE ZEMILJISTAA}

Zemijišni pokrivač pod ovim šumana je vrlo heterugen. Raznolikost pokrivaca uslovljena je velikom disjunktnosti ovih šuna, kgte se nogu sresti u svim dijelovima Bosne na višim nadmorskim visimama, tako da se 
razvijaju kako na karbonatnjm tako isto i na silikatnim supstratima.

\section{ZEMLJIŠTA NA KARBONATNIM SUPSTRATIMA}

Ove sume se razvijaju na zemljistima razvijenim na preteźno jedrim krečnjacima, dolomitima, a manje na silifikovanimbituminoznim, konglomeratižnim $i$ dolomitiziranim krečnjacima, kao i na seriji krečnjaka $i$ rožnjaka.

Za mrazišne šume smrče često su karakteristična zemljišta obrazovana na morenskim i soliflukcionim nanosima, npr. Igman, Vukovsko po1je. Osnovna karakteristika pojave ovih suma na zemljistima obrazovanim na karbonatnim supstratima je da se one mogu razvijati na svim predstavnicima serije, izuzev na nerazvijenim zemljistima iz klase (A) $-C$. Tako ih imamo na kalkomelanosolu (crnici), kalkokambisolu (smedje krecnjacko zemljište) i luvisolu (ilimerizovanom zemljistu) na krečnjacima 1 dolomitima, a na saharoidnim dolomi tima susrecemo najčešce dolomi tnu rendzinu.

lako su ova zemljišta razvijena na karbonatnim supstratima, vrlo Cesto imamo pojavu i sirovog humusa, \$to je uslovljeno, sa jednestrane, nepovoljnim sastavom క̌umskog otpada (iglice smrze, jele i bijelog bora), nepovoljnim klimatskim uslovima (mrazišta ili više nadmorske visine), kao i plitkocom $i$ suhocom stanista.

Na ovim maticnim supstratima ne javljaju se veliki elementarni areali pojedinog tipa zemljista, vec je struktura složena iz dva ilj tri clana. Zbog toga izdvojeni tipovi suma (osnovni kao i proizvodni) se moraju uzeti kao tvorevine koje na terenu ne cine vece površine vec grade kombinacije tipova.

Daljnja karakteristika ovih zemljista je da imaju visoku povrsinsku kamenitost, sto smanjuje produktivnu površinu za razvoj drveca, a kamenitost se u pravilu smanjuje od nižih razvojnih stadija prema razvijenijim tipovima zemljista (luvisolima).

\section{KALKOMELANOSOL (KRECNJACKA CRNICA)}

Ovaj tip zemljišta zauzima vece učsce u strukturi zemljišnog pokrivaca na vecim nadmorskim visinama i izrazenijim formama reljefa, $u-$ glavnom na jedrim krecnjacima i dolomitiziranim krečnjacima. Pouršinska 
kamenitost je vrlo visoka, a takodjer skeletnost soluma, koji je plitak i ne prelazi dubinu od $40 \mathrm{~cm}$.

Manje je zastupljen organogeni podtip $i$ preovladava organomineralni. Pojava sirovog humusa je vrlo cesta. Zbog skeletnosti, i plitkoce fizioloski aktivnog proflla ova zemljista imaju niske rezerve biljci pristupacne vode $i$ to je glavni razlog njegove smanjene produktivnosti.

\section{KALKOKAMBISOL (SMEDJE KRECNJACKO ZEMLJISTE)}

Kalkokambisol je najzastupljeniji član serije zemljišta nakrečnjacima, koji se nalazi pod ovim šumama i njegove karakteristike suzbog toga veoma heterogene. Pojavijuju se, uglavnom, na jedrim krečnjacima, a takodjer i na drugim varijatetima.

Površinska kamenitost je razliçita, ovisno of pojave slojeva prema pourşini terena, te može da bude $i$ vrlo velika.

Takodjer je skeletnost srednja, rjedje vrlo velika.

Debljina humusno-akumuli tivnog horizoṇta znatno može da varira, od par do $15 \mathrm{~cm}$ debljine.

Ova zemljišta su slabo obezbijedjena sa fosforom, a srednje sa ka] ijumom.

U proizvodnom pogledu od značaja je vodno-vazdusni režim, te smo ovaj tip zemljista podijelili u dvije varijante $i$ to: plitku,koja je slabije obezbijedjena sa biljci pristupačnom vodom i kserotermnije je staniste; i dublju, gdje je vodno-vazdušni režim znatno povoljniji.

Pojava sirovog humusa je $i$ ovdje evidentna.

\section{LUVISOL (ILIMERIZOVANO ZEMLJISTE) NA KRECNJAKU}

Ovo je najrjedji ¿̌lan serije zemljista na krečnjacima, koji se nalazi samo na zaravnjenijim potezima reljefa $i l i$ još cešce u depresijama, gdje dolazi do nagomilavanja $i$ ocuvanja zemljišnog materijala. Uglavnom se razvija na jedrim krečnjacima, kao $i$ na ostalim varijatetima, ali sa manjom učes talosti. 
Pouršinska kamenitost je riska ili skoro odsustvuje, kao i skeletnost profita.

Ovo su duboka zemljišta, dobro izražene stabilne poliodriche? strukture u argiluvichom Bt horizontu, te su stoga povoljnih vodrofizickih svojstava.

Usljed nepovoljnin k. inatskih uslova obrazovanja i sastava atpada $i$ na avom tipu zemljista se obrazuje sirovi humus.

\section{RENDZINA NA SAHAROLDNOM DOLOMITU}

Na kompleksu saharoidnog dolomita sireg podruça kupresa i Btgojna obrazovane su ove sume na rendzini, koja znatno preovladava llad ostalm tipovima zemlijsta iz ove serijo.

To su uglavnom povrsine bez znacajne poursinske kamenitosti, sredije: do slabe skeletnosti zenljišnog soluma.

Fizioloski aktivni profil iznosi oko $35 \mathrm{~cm}$, sa jasno izlvojeniri sirovim humusom debljine do $3 \mathrm{~cm}$.

Ovo su po mehanickon sastavu ilovače, srednje izražene strukture $i$ propusne za vodu te su zbog toga i suha stanista na kojina je veliko kolebanje stanja vlažnosti.

Primjend mineralnih djubriva. da bi se odstranio debalans $u$ hranidbcrom nivou posebno kalijuma $i$ fosfora, dolazi u obzir na dubljim varijantama.

\section{ZEMLJIŠTA NA SILIKATNIM SUPSTRATIMA}

Kako je već u uvodu naglašeno ove šume se razvijaju na zenljistina skoro svih silikatnih stijena. Najvažniji su pješcari i glinci (verfenske formacije), rožnjaci, kvarcni pjescari, glinci, filiti, kvarcporfori, konglomerati, silikatne brece, kao homogene maticne podioge sa jedne strane, a posebno su znacajne serije sastavljene iz glinacd, laporaca i pjesciara (jurski flis), zatim krecnjaka i rożnjaka.

Karakteristika razvoja zemljišta na ovin stijenama se ogleda $u$ prvorn redu u izostajanju nižih razvojnit stadija, zemljišta iz klase ne- 
razvijenih $i$ humusno-akumulativnih, što je uslovljeno brzill mehanickim trošenjem stijena, najčesce klasičnog karaktera. Najrasprostranjeniji tipovi zemijišta su distrični kanbisoli (kiselo-smedje zemijiste) i luvisoli (ilimerizovana zemljišta) iz razdjela automorfnih zemlijşa, a iz hidromorfnih pojavljuje se samo pseudoglej.

Površinska kamenitost je malena ili sasvill izostaje. Ovo su duboka do vrlo duboka zenljišta, a mogu biti beskeletna, do srednje skeletna, zavisno od stijene na kojoj se zemljišta obrazuju.

Pojava sirovog humusa je vrlo česta pod ovim šumama $i$ dostiže debljinu i do $10 \mathrm{~cm}$.

Za razliku od krečnjačkih supstrata, na silikatnim stijenama zemljista se javljaju kao homogene pedogenetske jedinice izgradjujuci velike pouršine elementarnih zemljišnih areala.

Na vecim nagibima $i$ otvaranjem sklopa moguća je pojava erozije a posebno na nekim supstratima, gdje se ističu pouršine sa rožnjakom i perm-karbonski škriljci i pješčari.

\section{DISTRICNI KAMBISOL (KISELO SMEDJE ZEMLJISTE)}

Maticna podloga ovih zemljišta je vrlo različita, ali se najčesce pojavljuju verfenski sedimenti (pješcari $i$ glinci), kvarcni pješcari, rožnjaci, glinci, kvarcporfiri, filiti kao homogene stijene (ali $i$ kombinacije, cineci serije sa istim stijenama ilj drugim članovima, kao što su krečnjaci, laporci, konglomerati, rožnjaci i dr.). Pouršinska kamenitost je znatno manja, $i l i$ ne postoji u poredjenju sa zemljištima na krečnjacima i dolomitima.

Ovo su duboka do vrlo duboka zemljišta, gdje fizioloski aktivni profil prelazi dubinu od $120 \mathrm{~cm}$. Solum je beskeletan do slabo skeletan, uglavnom odredjen vrstom stijene na kojoj se obrazuje. Zbog dubine fiziološki aktivnog profila, niskog sadržaja skeleta, ova zemijišta su povoljnih vodno-fizickih svojstava, a nepovoljna hemijska svojstva je moguce korigovati prinijenom mineralnih djubriva. Poseban značaj, kod ovih zemijista, ima primjena mineralnih djubriva za brže razlaganje sirovog humusa, koji se obrazuje pod ovim sastojinama. 


\section{LUVISOL (ILIMERIZOVANO ZEMLJISTE) NA SILIKATNIM STIJENAMA}

Luvisoli se obrazuju na istim maticnim podlogama, kao i prethodni tip, a mjestimično se susrecu i silifikovani krečnjaci, gdje zauzimaju zaravnjenije položaje $i$ manje nagnute padine. Beskamenite su povrsine $i$ slabe skeletnosti ili su beskeletni.

Kao i prethodni tip zemljista povoljnih vodno-fizickin svojstava, kisele je reakcije i slabo snabdjeveno sa fosforom $i$ kalijumon. I na ovim zemljištima javlja se sirovi humus, te primjena mineralnih djubriva može da pospiješi proces kruženja materije na staništu i poboljšava se istovremeno hranidbeni nivo zemljista.

\section{PSEUDOGLEJ NA KISELIM SILIKATNIM STIJENAMA}

rip zemljišta, pod ovim šumama, uglavnom ima primarno porijek10. Raspored slojeva je takav da ispod, po mehanickom sastavu lakšeg, se nalazi nepropusni sloj težeg, glinovitijeg zemijista. Najčesce su to serije pješcara-glinaca, pješčara-rožnjaka, pješcara-కkkiljaca i dr.

Ležanje nepropusnog sloja ili horizonta varira na dubini od 15 do $40 \mathrm{~cm}$.

Ova zemljista zauzimaju blage padine ili zaravnjene polozaje reljefa, bez površinske kamenitosti, i slabe skeletnosti profila.

U biljnoj proizvodnji, gazdovanju sa šumama na ovim zemljištima, osnovni problem je dubina ležanja površinske vode i trajanje mokre faze. Zbog načina zakorjenjivanja smrča podnosi ova staništabolje od jele.

Osim hidromeliorativnih zahvata, primjena mineralnih djubriva, zbog stvaranja sirovog humusa, daje dobre rezultate u povecanju produktivnosti staništa. 
Istraživani tipovi suma mogu se pojaviti i na brunipodzolu $i$ podzolu ali ne cine vece suvisle komplekse. Njihova pojava je, uglavnom, vezana za silikatne stijene jako bogate kvarcom, kao sto su kvarciti, kvarcni pješčari i roźnjaci.

Ovo su srednje produktivna stanista, a proizvodnost bi se mogla značajno povećati meliorativnim zahvatima, koji bi vodili bržem razlaganju sirovog humusa, gdje mogu da budu mobilisane značajne količine hranjivih elemenata, što se postiže primjenom mineralnih djubriva NPK, ili masadn.jom leguminoza.

\section{STANJE ŠLIYSKOG FONDA}

Tipovi šuma u kojima su ova istraživanja izvršena čine samo dio siroke kategorije šuma koja je u knjizi "Stanje šuma u SR BiH - preilla inventuri šuma na velikim površinama u 1964-1968. godini" ( $M$ a t: $i c$, et a1., 1971.) obradjena pod nazivom: "Ciste i mješovite šume jele 1 smrč $i$ mješovite sume jele, smrče i bukve". Stoga će se u daljem tekstu, radi odgovarajucih uporedjenja, koristiti podaci iz tog rada.

\section{OPŚTI PODACI}

Opšti podaci za tipove šuma koji su ovim istrażivanjima obuhvaceni su sljedeci:

Približna pouršina na kojoj se nalaze u BiH iznosi 67.000 ha. sume na zemijištima obrazovanim na krečnjacima $i$ dolomitima participiraju sa oko $75 \%$, a na zemljistima na silikatnim stijenama sa $25 \%$. Prosječna nadmorska visina iznosi $1.155 \mathrm{~m}$.

Prosježna nadmorska visina osnovnih tipova šuma na zemljištima na krečnjackim $i$ dolomitnim stijenama je $1.187 \mathrm{~m}$, a na zemijistima nasilikatnim stijenama $1.067 \mathrm{~m}$. Istraživanjem obuhvaćeni tipovi šuma na zemljistima obrazovanim na krečnjačkim $i$ dolonitnìn supstratima imaju skoro 
istu prosječnu nadmorsku visinu kao i šira kategorija čistih i mješovitih šuma jele, smrče $i$ bukve dok se istraživani tipovi šuma na zemljištima na siljkatnim stijenama nalaze na nešto vecoj nadmorskoj visini.

Približna procentualna raspodjela površina istraživanjem obuhvacenih šuma na pojedine ekspozicije prikazana je u tabeli br. 1.

Tabela br. 1

\begin{tabular}{lccccc}
\multicolumn{1}{c}{ Tip šume } & Sjeverna & 1stočna & Južna & Zapadna Ravno \\
\hline $\begin{array}{l}\text { Sve šume } \\
\text { Sume na zemljištima krečnja- }\end{array}$ & 28 & 22 & 24 & 24 & $?$ \\
ka i dolomita & 28 & 21 & 25 & 24 & 2 \\
$\begin{array}{l}\text { Sume na zemljištima silikat- } \\
\text { nim stijenama }\end{array}$ & 29 & 25 & 22 & 23 & 1 \\
\hline
\end{tabular}

Uporedjenjem ovih podataka sa podacima za širu kategoriju ovin Šuma iz Inventure šuma, zapaža se veće učešce južnih ekspozicija na račun sjevernih, što je i razumljivo, ako se uzme u obzir činjenica da istraživanjem nisu obuhvaçene mješovite šume jele, smrče $i$ bukve. One se, kako je poznato, znatnim dijelon nalaze na sjevernim ekspozicijama.

Nagib tla je za istraživane tipove šuma manji od podataka iz. Inventure suma. Prosječna inklinacija za sve istraživane tipove šuma je $12,4^{\circ}$. Za tipove šuma na zemljištima na krečnjačkimi dolomitnim stijenama iznosi $12^{\circ}$, a za tipove šuma na zemljištima na silikatnim stijenama $15^{\circ}$. Veci nagib terena na zemijištima na silikatima registrovani sui Inventurom šuma za širu kategoriju ovih šma. Njeni autori (M a $t i c$, at al., 1971.) objašnjavaju taj podatak vecom zastupljenošcu platoa $i$ zaravni na krečnjačkim nego na si îkatnim supstratima.

Manji stepeni inklinacije istrażivanih tipova suma nego šire kategorije javili su se zbog toga sto se oni nalaze $i$ na krečnjacima $i$ na silikatima na blažim padinana i u vecoj mjeri na zaravnima i platoima. 0sim podataka navedenih u prethodnim poglavljima ovog rada na to ukazuje i podatak o zastupljenosti ravnih terena u podacima o ekspozicijama. Ti tereni u pouršini šire kategorije suma participiraju s tu (društvene sume), a $u$ istraživanim tipovima šuma sa $2 \%$. 
Prosječni boniteti staništa (na bazi visina stabala) za najzastupljenije vrste drveća (po zapremini) su sljedeci:

jela 2,7 ; smrča 3,2 ; bijely bor 3,0 ; bukva 3,6 .

Bonitetri razred staništa za smrču isti je kao u podacima Inventura suma, dok je za jelu za 0,2 bolji, a za bukvu za 0,4 losiji.

Prosjecrni boniteti stanista na zem] i tima obrazovaninnakrećnjacima $i$ dolomitima iznosili su:

za jelu 2,6 ; smru 3,3 ; bijeli bor 3,3 i bukvu 3,6 , " na zemljistima na silikatrim stijenama onj iznose:

za jelu 2,9; smrcu 3,0; bijeli bor 2,2 i bukvu 3,5 .

Na zemljištima na silikatnim stijerama prosječni bonitet stamista bolji je za smrču, bijeli bor i bukvu nego za jelu. Za širu kategoriju ovih suma prosjecni bonitet stanista bolji je i zajelu na zemijištima na silikatnim stijenama. Za uticaj zemljišta na silikatima na ve-licinu bonitetnog razreda nalaze autori Inventure suma objašnjenje a ma. njoj prosjecnoj radmorskoj visini tih zemljišta. I za tipove sund obuhvacene ovim istraživanjima, bila je prosjecna madmorska visina zenljisto na silikatima manja od zemljišta na krečnjacima. Uticaj tog faktora na bonitetni razred jele nije se, po našem mišljenju, ispoljio pozitivno jer su platoi i zaravni i podnožja padina koje se iz njih izdižu obuhvaceni mazevima koje jela teže podnosi kao i zbog veće zastupljenusti južnih ekspozicija koje joj inanje pogoduju.

Prosječni stepen prekrivenosti tla krošnjama stabala $i$;nos $i$ za istrażivane tipove šuma 0,61 . Za tipove suma na zemljištima obrazovanim ná krečnjacima dolomitima on iznosi 0,59 , a za tipove suma na zemljištima silikatima 0,65 . Zastrtost tla krošnjama stabala u istraživanim tipovima suma manja je za 0,15 od prekrivenosti tla u društvenim sumama šire kategorije za koje Inventura šuma daje podatke. Nedovoljna prekrivenost t1a krošnjama stabala (taksacioni prag $5 \mathrm{~cm}$ ) kazuje nam da prirodni potencijal ovih staništa nije dovoljno iskorisćen $i$ da bi na njima prirast (i prinos) drvne mase, uzevis u prosjeku, mogao biti veci od uturdjenog. Prednost stanista na zemijištima na silikatima ispoljels je i s obziron na

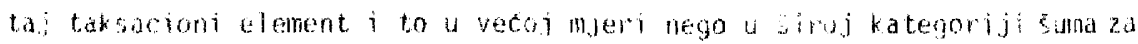
koje se ndata poreci u truenturi sumia. 


\section{ZASTUPLJENOST I KVALITET PODML.ATKA}

U podmladak su surstane biljke $i$ stabalca of $10 \mathrm{~cm}$ visine do 5 $\mathrm{cm}$ prečnika na $1,3 \mathrm{~m}$ visine iznad $t 1 \mathrm{a}$.

U ponik su svrstane biljke visoke do $10 \mathrm{~cm}$.

I) Sumalma koje su obuhvacone ovim istraživanjem brojnost i stanije podmlatka bilo je sljedece:

Broj tiljaka podmlatka po hektaru iznosi u prosjeku:

Na zemljistima na krečnjacima na silikatima oba tipa

\begin{tabular}{lrrr} 
visine $10-15 \mathrm{~cm}$ & 3.947 & 5.398 & 4.343 \\
Visine $50.130 \mathrm{~cm}$ & $901^{*}$ & 2.101 & 1.228 \\
debljine do $5 \mathrm{~cm}$ (na 1,3 m) & 719 & 1.724 & 993 \\
\hline UKUPNO & 5.567 & 9.223 & 6.564
\end{tabular}

U ukupnom broju biljaka jodmlatka učesce pojedinih vrsta drveca bilo je sljedece:

Na zenlizstima

jela

smróa

bijeli bor

bukva i ostali lišcari

UK!IPNO na krečnjacima
i dolonitima

$(x)$ na silikatima oba tipa

(di)

$\left(\begin{array}{c}\prime \prime \prime \\ w)\end{array}\right)$

41

47

3

$48 \quad 46 \quad 47$

$4 \quad 1 \quad 3$

9

100

100

Od navedenog broja biljaka podmlatka bilo je:

Na zemljištu $\quad \begin{array}{ccc}\text { na krečnjacima na silikatima oba tipa } \\ \text { idolomitima og }\end{array}$

zastarčeno

19

20

19

ostećeno

15

16 15

UKUPNO

34

36

34


Od ukupnog broja položenih primjernih pouršina ponik se javio u 49\% slučajeva. Na zemljištima obrazovanim na krečnjacima i dolomitimau $48 \%$ sluçajeva, a na zemljištima na silikatima u $52 \%$ slućajeva.

Navedeni broj biljaka podmlatka nedovoljan je za normalno prirodno obnavljanje tih šuma, pogotovo ako se ima u vidu da je oko $34 \%$ podmilatka zastarčeno jli osteceno.

Na zemljištima sa silikatima broj biljaka podmlatka osjetno je veči nego na zemljištima na krečnjačko-dolomitnim stijenama.

\section{VELIĆINA I KVALITET DRVNE ZALIHE}

Zalihu tipova suma (na bazi sveukupne drvne mase i taksacionog praga od $5 \mathrm{~cm}$ ) obuhvacenih ovim istraživanjima sacinjavaju sljedece vrste drveca u omjerima iskazanim u procentima (tabela br. 2).

Tabela br. ?

\begin{tabular}{|c|c|c|c|c|c|}
\hline \multirow{3}{*}{ Vrsta drveta } & \multicolumn{4}{|c|}{ Tip zenl jista na } & \multirow{3}{*}{$\begin{array}{l}\text { Sve } \\
\text { grupe }\end{array}$} \\
\hline & \multicolumn{3}{|c|}{ krečnjaku i dolomitu } & \multirow{2}{*}{$\begin{array}{c}\text { silikat- } \\
\text { nim } \\
\text { duboka }\end{array}$} & \\
\hline & duboka & plitka & $\begin{array}{l}\text { obje } \\
\text { grupe }\end{array}$ & & \\
\hline Jela & 35,2 & 32,4 & 33,9 & 29,7 & 32,8 \\
\hline Simrēa & 56,3 & 49,8 & 53,2 & 54,7 & 53,6 \\
\hline Bijeli bor & 7,7 & 15,9 & 11,6 & 13,2 & 12,0 \\
\hline Crni bor & - & + & + & - & + \\
\hline Bukva i ostali lišcari & 0,8 & 1,9 & 1,3 & 2,4 & 1,6 \\
\hline Ukupno & 100 & 100 & 100 & 100 & 100 \\
\hline
\end{tabular}

Od vrsta drveca koje su surstane u ostale lišćare bile su najzastupljenije breza, javor gorski $i$ joha dok se crni bor javio samo u tragovima.

Udio bukve $i$ ostalih lišcara $u$ istraživanim tipovima iznosi svega $1,6 \%$ dok je njihov udia u siroj kategoriji ovin కuma $39,5 \%$. 
Prosječna veličina zalihe (sveukupna drvna masa pri taksacionum pragu od $5 \mathrm{~cm}$ ) svih istraźivanih tipova suma iznosi $286,9 \mathrm{~m}^{3} / \mathrm{ha}$. Od toga otpada na cetinare $282,4 \mathrm{~m}^{3}$, a na 1 isçart: $4,5 \mathrm{~m}^{3}$. Ova zaliha manja je za $19,7 \mathrm{~m}^{3}$ od prosjecre zalihe cijele zire kategorije suma obradjene $u$ Inventuri šuma

Podaci o prosječnim veijicinama zal iha istraživanjem nbunvacenih suma $i$ o procentualnoj raspodjel i zal iha po debljinskim klasama izlożeni su u tabeli br. 3.

Veliçina zalihe no hektaru manja je na svakom tipu zemljišta od sire kategorije ovih suma obradjenih u Inventuri šuma.

$S$ obzirom na velicine nomalnih zal iha koje daje Matic ( $M$ a* $t i t, 1963$.$) za čiste jelove i l i$ ciste smrceve sastojine za III bonitetni razred stanista, koje za stanje u sredini curnusa iznose, kada se preracunaju na sveukupnu drunu masu, 352 , odnosno $356 \mathrm{~m}^{3} / \mathrm{ha}$, utvrdjene zalihe istrazivanih tipova suma su premale.

Raspodjela zalihe četinara po debljinskim klasama ne odstupa $u$ vecoj mjeri od normalne. Wcešce drbljinske klase $5-10 \mathrm{~cm} n i j e$ pri uturdjivanju normainih sasta!o razmatrano. Cijeni se da treba da se krece oko 2-3\%. klasa od 10-15 cm treba da ucestuuje u zalihi sa oko $5 \%$, a naredna sa oko 8\%. Debljinska klasa of $20-30 \mathrm{~cm}$ trebalo bi da je zastupljena sa oko $21 \%$ a klasa ad $30-50 \mathrm{~cm}$ sa oko $46 \%$.

Ostatkom do $100 \%(17,5 \%)$ treba da učestvuje debljinska klasa od $50-80 \mathrm{~cm}$.

Raspodjela zalina iz tabele or. 3 po kvalitetnim klasama tehnicke klasifikacije (M a t ic et al., 1971.) prikazana je u tabeli br. 4.

Kvalitet zalihe cetinara s obzirom na tehnicku upotrebljivost njihovih stabala dosta je dobar. Kvalitet četinara na dubokim zemljištima na silikatnim stijenana nešto je bolji nego na zemljištima na krečnjačkim i dolomitnim supstratima.

Kvalitet lišçara veoma je loš. Medjutim, pošto je udio lišcara u ovim sumama malen, krece se do $2 \%$, stanje se lako može poboljšati.

Loś kvalitet lišcara, posebno bukve, posljedica je djelovanja više faktora od kojih kao najuticajniji izdvajamo klimatski. 


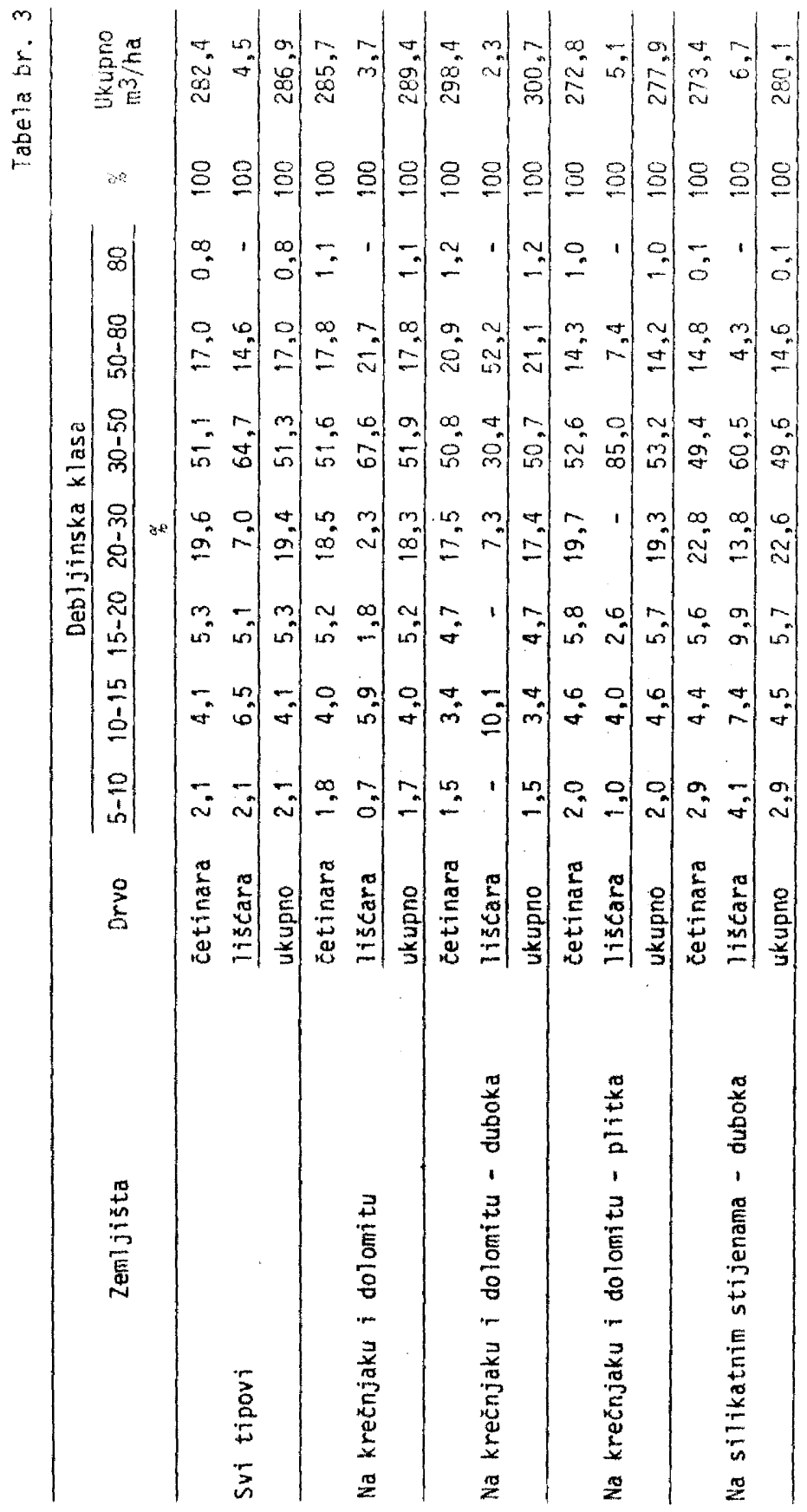


Tabela or. 4

\begin{tabular}{|c|c|c|c|c|c|}
\hline \multirow{2}{*}{ Zemljista } & \multirow{3}{*}{ Drvo } & \multicolumn{4}{|c|}{ Tehnick + klasa } \\
\hline & & 1 & 11 & II! & IV \\
\hline & & \multicolumn{4}{|c|}{$\because$} \\
\hline \multirow{2}{*}{ Svi tipovi } & Eetinara & 48,3 & 34,4 & 14,4 & 2,9 \\
\hline & liscara & 2.9 & 27,1 & 38,1 & 31.9 \\
\hline \multirow{2}{*}{ Na krečnjaku i dolomitu } & Eetinara & 45,2 & 35,7 & 15.7 & 3,4 \\
\hline & lišcara & 4.5 & 30.5 & 39,0 & 26,0 \\
\hline \multirow[t]{2}{*}{ Na krečnjaku i dolomitu - duboka } & Eetinara & 45,8 & 37,6 & 13.3 & 3.3 \\
\hline & liscara & - & 41,8 & 38.6 & 19.6 \\
\hline \multirow{2}{*}{ Na krečnjaku i dolomitu - plitka } & Eetinara & 44,4 & 33,5 & 18,5 & 3,6 \\
\hline & lišcara & 6,6 & 25,2 & 39.2 & 29,0 \\
\hline \multirow{2}{*}{ Na silikatnim stijenama - duboka } & cetinara & 57.1 & 30,7 & 10,6 & 1.6 \\
\hline & lišcara & 0,6 & 22,1 & 36.8 & 40,5 \\
\hline
\end{tabular}

Raspodjela zalihe po kvalitetnim klasama, uzgojno-tehnickeklasifikacije (M a $t i c$ et al., 1971.) iznijeta je u tabeli br. 5.

Tabela br. 5

\begin{tabular}{|c|c|c|c|c|}
\hline & & & ojna $k$ & sa \\
\hline Zemljista & Drvo & 1 & 11 & III \\
\hline & & & $\because$ & \\
\hline Svi tipovi & Cetinara & 36,0 & 43,0 & 21.0 \\
\hline & liscara & 0,2 & 17.2 & 82.6 \\
\hline Sva na krečnjaku i dolomitu & cetinara & 32.4 & 45,2 & 22,4 \\
\hline & liscara & - & 18,9 & 81.1 \\
\hline Na krežnjaku i dolomitu - duboka & Cetinara & 34,9 & 44,2 & 20,9 \\
\hline & lišcara & - & - & 100,0 \\
\hline Na krecnjaku i dolomitu - plitka & cetinara & 29,5 & 46,3 & 24,2 \\
\hline & lišcara & - & 27,8 & 72,2 \\
\hline Na silikatnim stijenama - duboki & Cetinara & 46,4 & 36.7 & 16.9 \\
\hline & I iscara & & & \\
\hline
\end{tabular}


U III klasu uzgojno-tehničke klasifikacije surstana su stabla koja u sastojini ne bi smjela da postoje. Učesce četinara u toj klasi po zapremini dosta je veliko, a lišcara ogromno. Zbog velikag učesća četinara u ukupnoj zalihi ovih suma (do 99\%), popravljanje stanja njihove zalihe trajace duže.

Kvalitet četinara na zemljištima na silikatnim stijenama nešto je bolji nego na zemljistima na krečnjackim $i$ dolomitnim supstratima.

Uporedjenjem s podacima iz Inventure šuma za širu kategoriju కuma bukve, jele $i$ smrče, vidi se da je kvalitet cetinara tih suma skoro isti kao u istrazivanim.

\section{ZAPREMINSKI PRIRAST}

Pošto se $i$ širom kategorijom šuna jele, smrče $i$ bukve $i$ istraživanjem obuhvacenih tipova suma gazdovalo u proteklom periodu pretežno prebornim ili skupinasto prebornim sistemom gazdovanja to ca se za mjerilo dosadašnje produkcije drvne mase navedenih šuma koristiti velizina njihovog godišnjeg zapreminskog prirasta po hektaru. On je izračunat kao prosječni periodični prirast u periodu za 10 godina $i$ odnosi se na sveukupnu drvnu masu i taksacioni prag od $5 \mathrm{~cm}$.

Velicine zapreminskih prirasta istrażivanih suma date su u tabelt br. 6. Pod ostalim cetinarima u toj tabeli podrazumijeva se bijeli bor jer je crni bor i u zalihi i u prirastu istraživanih šuma bio veoma malo zastuplien.

Udio pojedinih vrsta u prirastu skoro je isti kao $i$ u zalini (vidi tabelu br. 3).

Zapreminski prirast na dubokim zemljistima silikatnimstijenama je najveći. Na dubokim zemljištima na krečnjacima i dolomitima veći je nego na plitkim. Isti odnosi u pogledu uticaja vrste zemljišta i njegove dubine utvrdjeni su $i$ Inventurom suma.

Apsolutne veličine zapreminskog prirasta iz tabele br. 6 ne odrazavaju prirodni proizvodni potencijal navedenih stanista, posebno na dubokim zemijiśtima na krečnjacima. raj potencijal je sigurno veći. To poturdjuju, osim podataka o stepenu prekriverosti tla krośnjama (nali su) 
Tabela br. 6

\begin{tabular}{|c|c|c|c|}
\hline & & \multirow{2}{*}{\multicolumn{2}{|c|}{$\begin{array}{l}\text { Godižnji zapreminski prirast } \\
\text { sveukupne drvne mase }\end{array}$}} \\
\hline \multirow[t]{2}{*}{ Zemljista } & \multirow{2}{*}{ Vrsta drveca } & & \\
\hline & & $m^{3} / h a$ & $\because$ \\
\hline \multirow{5}{*}{ Svi tipovi } & jela & 2.26 & 32 \\
\hline & smrča & 4,05 & 57 \\
\hline & ostali Eetinari & 0.74 & 10 \\
\hline & liscari & 0,09 & 1 \\
\hline & sve & 7.14 & 100 \\
\hline \multirow{5}{*}{$\begin{array}{l}\text { Sva na krecnjaku i do- } \\
\text { lomitu }\end{array}$} & jela & 2.19 & 34 \\
\hline & smrča & 3,62 & 55 \\
\hline & ostali cetinari & 0.64 & 10 \\
\hline & Ijšcari & 0,06 & 1. \\
\hline & sve & 6,51 & 100 \\
\hline \multirow{5}{*}{$\begin{array}{l}\text { Na krečnjaku i dolomi- } \\
\text { tu - duboka }\end{array}$} & jela & 2,65 & 38 \\
\hline & smrča & 3,95 & 57 \\
\hline & ostali cetinari & 0,26 & 4 \\
\hline & liscari & 0,03 & 1 \\
\hline & sve & 6.89 & 100 \\
\hline \multirow{5}{*}{$\begin{array}{l}\text { Na krečnjaku i dolomi- } \\
\text { tu - plitka }\end{array}$} & jela & 1,71 & 28 \\
\hline & smrča & 3,28 & 53 \\
\hline & ostali cetinari & 1,03 & 17 \\
\hline & liscari & 0,11 & 2 \\
\hline & sve & 6,13 & 100 \\
\hline \multirow{5}{*}{$\begin{array}{l}\text { Na silikatnim stijena- } \\
\text { ma - duboka }\end{array}$} & jela & 2,46 & 28 \\
\hline & smrča & 5,19 & 59 \\
\hline & ostali četinari & 1,01 & 11 \\
\hline & Iiscari & 0.16 & 2 \\
\hline & sve & 8,82 & 100 \\
\hline
\end{tabular}

i ogromna variranja u velicini zapreminskog prirasta oglednih pouršina $i$ standardne devijacije velicine prirasta (prosječna odstupanja izmjerenih prirasta od iskazane prosjecne velicine, 0 b $r$ a d o v i $c$, et al., 1959) koje se krecu od \pm 3 do $\pm 7,5 \mathrm{~m}^{3} /$ ha. Za iskazan prosjeeni iznos zapreminskog prirasta (tabela br. 6) Suma na dubokim zemljistima na krečnjackim i dolomitnim stijenama od $6,89 \mathrm{~m}^{3} / \mathrm{ha}$, standardna devijacija iznosi $\pm 6,16$ $m^{3}$. 
U okviru prikaza karakteristika osnovnih tipova suma navedene su $i$ standardne devijacije vaźnijih taksacionih elemenata (III poglavlje).

Najvaznije mjere koje ce dovesti do boljegkorizcenja proizvodnog potencijala istrazivanjem obuhvacenih stanista izložene su u okviru opisa proizvodnin tipova ovih suma (IV poglavlje).

\section{OSNOVNI TIPOVI SUMA}

U ovom dijelu rada date su os novne ekolosko-vegetacijske i proiavodne karakteristike osnornih tipova suma koji su obuhvaceni ovim istrazivanjem.

sume jele i smrče, smrče, smrče i bijelog bora nalaze se u klimaregionalnom pojasu šuma bukve i jele sa smrčon. Dok su sume jele i smrce, odnosno smrče i bijelog bora sekundarnog karaktera, šume smrče predstavljaju trajne stadije vegetacije usiavljene mikroklimatskim ili edafskim faktorima.

Svojstva zemljista u ovim sumama data su na osnovu morfoloskin istraživanja na terenu, te su navedena samo ona svojstva koja mogu inati veći značaj za produktivnost stanista.

0 proizvodnim karakteristikama obavjestavaju nas podaci o bonitetu stanista $i$ onjeru smjese zastupljenih vrsta drveca, stepenu zastrtosti tla krošnjama stabala, veliçinf godišnjeg zapreminskog prirasta, velicini zalihe $i$ njenoj raspodjeli po debljinskim klasama, kvalitetu zalihe s obzirom na tehnicku upotrebljivost, kao $i$ podaci o brojnnsti $i$ kvali tetu podmlatka.

Bonitet stanista onih vrsta drveca, koje 4 zalihi ucestrujus malim procentom (do $5 \%$ ), treba primiti s rezervom jer nije realan. Za iskazane prosjecne velicine pojedinih pokazatelja ekološko-proizvodnih kareakteristika osnovnih tipova suma izracunati su iosnovni matematskostatisticki pokazatelji:

- maksimalna relativna greska " $g$ " za 95\% vjerovatnocu i

- standardna devijacija "s". 
Osnovni tipovi suma obradjeni su u ovom radu sa ekolosko-proizvodnog stanovista.

Vegetacijske karakteristike date su na osnovu fitocenoloskin snimaka. Za svaki osnovni tip naveden je karakteristicni sastav drveca, grmija i prizemne flore, gdje su istaknute zastupljenije vrste koje imaju odredjeni indikatorski $i$ dijagnosticki značaj.

U podacima o proizvodnim karakteristikama iskazani su:

- omjeri smjese pojedinih vrsta drveca na bazi sveukupne zapremine stabala za taksacioni prag od $5 \mathrm{~cm}$,

- bonitetni razredi stanista na bazi visina stabala.

- zastrtost tla krosnjanla stabala pri taksacionom pragu od $5 \mathrm{~cm}$,

- druna zalina - sveukupnom zapreminom stabala pri taksacionom pragu od $5 \mathrm{~cm}$,

- godišnji zapreminski prirast - sveukupnom zapreminom uz taksacioni prag od $5 \mathrm{~cm}$.

Zastupijenost pojedinih ekspozicija prikazana je brojem primjernih krugova od ukupno položenih. Ekspozicije su označene njihovim pocetnim slovima. Slovom "R" označeno je ravno tlo.

Kvalitetna struktura zalihe iskazana je kvalitetnimklasama tennicke klasifikacije ( $M$ a $t i c$ et al., 1971).

U okviru podataka o podmlatku dat je broj biljaka podmlatka svih sumskih vrsta drveca koji je na krugovima odredjenih radijusa zapaien.

Za izradu pregleda osnovnih tipova suma poslužili su nam podaci "Inventure suma na velikim površinama", kao i brojni naueni i strucni radovi o sumama jele $i$ smrče, smrče, smrče $i$ bijelog bora. 


\section{PREELED OSNOVNIH TIPOVA SUMA}

\section{SUME SMRČE I BIJELOG BORA, JELE I SMRCE I SMRCE"}
A. sume smrce $i b i j e l o g$ bor a

\begin{tabular}{|c|c|c|c|}
\hline \multirow[b]{2}{*}{$N$ a z i v } & \multicolumn{3}{|c|}{ Broj primjernih krugova } \\
\hline & $\begin{array}{l}\text { inventure } \\
\text { suma }\end{array}$ & dopunskin & ukupno \\
\hline 1 & 2 & 3 & 4 \\
\hline $\begin{array}{l}\text { 1. Sume smrče i bijelog bora na kalko- } \\
\text { melanosolu }\end{array}$ & 10 & 9 & 19 \\
\hline $\begin{array}{l}\text { 2. Sume smrce i bijelog bora na dolo- } \\
\text { mitnoj rendzini }\end{array}$ & 9 & 23 & 32 \\
\hline $\begin{array}{l}\text { 3. Sume smrče i bijelog bora na plit- } \\
\text { kom kalkokambisolu }\end{array}$ & 10 & 3 & 13 \\
\hline $\begin{array}{l}\text { 4. Sume smrke i bijelog bora na dubo- } \\
\text { kom kalkokambisolu }\end{array}$ & 10 & 8 & 18 \\
\hline $\begin{array}{l}\text { 5. Sume smrče i bijelog bora na luvi- } \\
\text { solu na krečnjaku }\end{array}$ & 12 & 1 & 13 \\
\hline $\begin{array}{l}\text { 6. Sume smrce i bijelog bora na plit- } \\
\text { kom districnom kambisolu }\end{array}$ & 2 & - & $2 * \star$ \\
\hline $\begin{array}{l}\text { 7. Sume smrče i bijelog bora na dubo- } \\
\text { kom distričnom kambisolu }\end{array}$ & 7 & 21 & 28 \\
\hline $\begin{array}{l}\text { 8. Sume smrce i bijelog bora na luvi- } \\
\text { solu na silikatnim stijenama }\end{array}$ & 1 & - & $1 * *$ \\
\hline $\begin{array}{l}\text { 9. Sume smrce i bijelog bora na pseu- } \\
\text { dogleju }\end{array}$ & 1 & - & $1^{\star *}$ \\
\hline
\end{tabular}

\section{B. sume je le ismre}

1. Sume jele i smrce na kalkomelanosolu

2. Sume jele i smrce na plitkom kalkokambi solu

\footnotetext{
- "VI" je oxnaka za sve cume, koja je data u okvimu opăte klaaifikacije tipova arma $u$ BiH.

** Oanovni tipovi sume male sastupljenosti nisu obradjeni.
} 


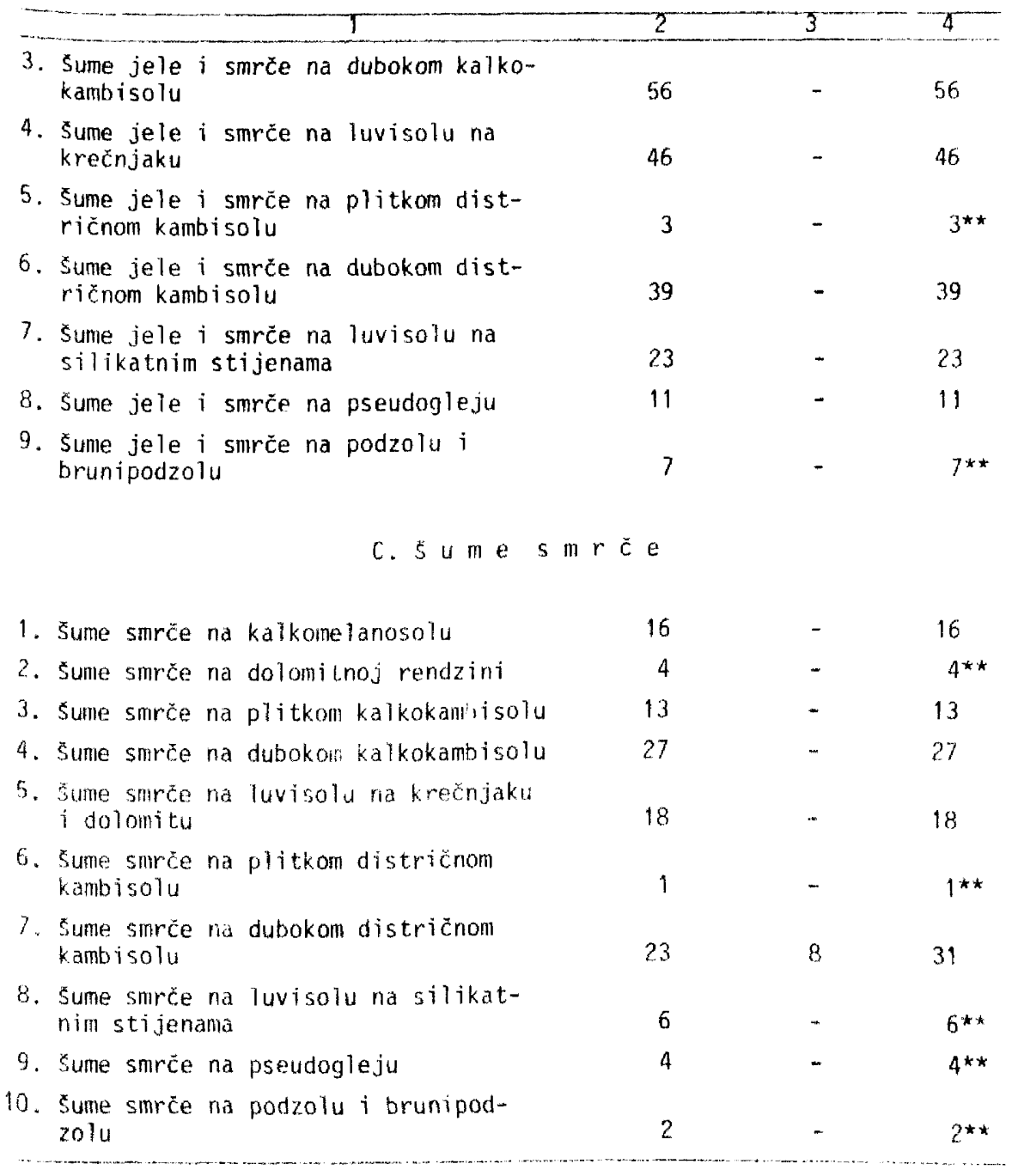




\section{EKOLOSKO-PROIZVODNE KARAKTERISTIKE OSNOVIIIH TIPOVA. SLMAA}

\section{A. SUME SMRČE I BIJELOG BORA}

OSNOVNI TIP: VI-a-1

SUME SMRCE 1 BIJELOG BORA NA KAL KOMELANOSOLU

a) orografskekarakteristike

Prosječna nadmorska visina: $1.242 \mathrm{~m}, \mathrm{~g}= \pm 3 \mathrm{~s}= \pm 73 \mathrm{~m}$

Prosjecna inklinacija: $13^{\circ}, g= \pm 27,5= \pm 7.3^{\circ}$

Ekspozicija: $S=2, I=7, J=6, Z=4, R=0$ krugova.

b) 2 em 1 jis $t e$

Matična podloga: Preovladavaju jedri krečnjaci, a rjedje mogu biti zastupljeni i dolomitizirani krečnjaci.

Svojstva zemljista: Povrşinska kamenitost je vrlo velika na površinama pod ovim tipom šume. Erozija je vrlo rijetka $i$ to povrşinska slabog intenziteta. Dubina profila u prosjeku iznosi $25 \mathrm{~cm}$, a može da bude $i$ do $35 \mathrm{~cm}$. Humusno-akumulativni horizont je bogat humusom. iznad kojeg se vrlo ces to obrazuje i sirovi humus debljine oko $3 \mathrm{~cm}$.

Srednje je skeletan, a po mehanickom sastavu ilovạ a do glinuza. Zbog plitkoce soluma i skeletnosti ova zemljista se vrlobrzo isusuju, te su ona vrlo kserotermna staništa.

c) Vegetacijskekarakteristike

Sastav drveca: Bijeli bor i smrča su glavne vrste, dok se jela javlja pojedinaźno ili grupimično.

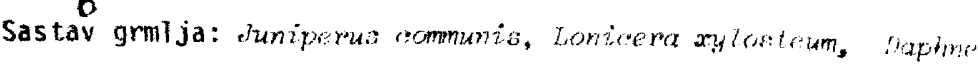
mesereum, Rhamnus fallax. 
Sastav prizemne flore: Brachypodiwn pinnatuon, Hel ianthemum n!... mularium, Euphorbia mygdaloides, Festuca pratenais, Bromus evectus, il ieracium pilosella, Aearom europaeum, od mahovine suzastupljene vrste iz rodova: Dicranum, Hylocomium, Rhytidiadelphus, Pleurozium.

d) Produkcionekarakteristike

Vrsta drveca $i$ omjer smjese: smrča 0,34 ; bijeli bor 0.55 ; bukva 0,03 .

Bonitetni razred stanista : smrza $I I I, 0 ;$ bijeli bor $\llbracket 1,8$.

Zastrtost tla krošnjama : 0,$62 ; g= \pm 17 \%, s= \pm 0,21$

\begin{tabular}{lrlr} 
Drvna zaliha & $\left(\mathrm{m}^{3} / \mathrm{ha}\right)$ & & Godišnji zapreminski prirast $\left(\mathrm{m}^{3} / \mathrm{ha}\right)$ \\
jela & 19,5 & jela & 1,09 \\
smrča & 92,9 & smrča & 2,74 \\
bijeli bor & 149,6 & bijeli bor & 3,00 \\
crni bor & 3,4 & crni bor & 0,03 \\
bukva & 8,9 & bukva & 0,25 \\
\hline Ukupno & 274,3 & ukupno & 7,11 \\
$\mathrm{~g}= \pm 34 \%, \mathrm{~s}= \pm 193,3 \mathrm{~m}^{3}$ & & $\mathrm{~g}= \pm 30 \%, \mathrm{~s}= \pm 4,46 \mathrm{~m}^{3}$
\end{tabular}

PROCENTUALMA DEBLJINSKA STRUKTURA ZALIHE

\begin{tabular}{lrrrrrrr}
\hline $\begin{array}{l}\text { Debljinska klasa } \\
\text { (cm) }\end{array}$ & $5-9,9$ & $10-$ & $20-$ & $30-$ & $50-$ & 80 i \\
\hline Jela & 6,5 & 36,6 & 16,5 & 40,4 & - & - & 100,0 \\
Smrča & - & 13,5 & 35,1 & 48,5 & 2,9 & - & 100,0 \\
Bijeli bor & 0,3 & 7,7 & 11,0 & 77,3 & 3,7 & - & 100,0 \\
Crni bor & - & - & - & - & 100,0 & - & 100,0 \\
Bukva & - & 13,7 & - & 86,3 & - & - & 100,0 \\
\hline Sve vrste drveca skupa & 0,6 & 11,8 & 19,1 & 64,3 & 4,2 & - & 100,0
\end{tabular}


KVALITETNA STRUKTURA ZALIHE ( $(\mathrm{x}$ )

\begin{tabular}{|c|c|c|c|c|c|}
\hline Tehnička kvalitetna klasa & 1. & 2. & 3. & 4. & Ukupno \\
\hline Jela & 86,8 & - & 8,1 & 5,1 & 100,0 \\
\hline Simrža & 51,4 & 22,2 & 22,7 & 3,7 & 100,0 \\
\hline Bijeli bor & 65,2 & 21,4 & 12,7 & 0,7 & 100,0 \\
\hline Crrif bor & - & 100,0 & - & - & 100.0 \\
\hline Bukva & 13.7 & 6.9 & 49,4 & - & 100,0 \\
\hline Sve vrste drveca skupa & 59.6 & 21,6 & 16,8 & 2,0 & 100,0 \\
\hline
\end{tabular}

BROJ BILJAKA PODMLATKA POHA (komada)

\begin{tabular}{lccccc} 
Vrsta drueta & $\begin{array}{c}\text { Visine } \\
10-50 \mathrm{~cm}\end{array}$ & $\begin{array}{c}\text { Visine } \\
50-130 \mathrm{~cm}\end{array}$ & $\begin{array}{c}\text { Debljine } \\
0-5 \mathrm{~cm} \mathrm{na} 1,3 \mathrm{~m}\end{array}$ & Ukupno \\
\hline Jela & 1.026 & - & 233 & 1.259 \\
Smrča & 1.395 & 207 & 368 & 1.970 \\
Ostali lišcari & 1.026 & - & - & 1.026 \\
\hline Ukupno & 3.447 & 207 & 601 & 4.255 \\
\hline
\end{tabular}

Omjer smjese po broju biljaka podmlatka: jela 0,30 ; smrča 0,46 ; ostali lišcari 0,24 .

Podmladak nije zastarčen. Ošteceno je $14 \%$ od ukupnog broja biljaka podmlatka.

Podmladak se javio pojedinazno rasporedjen u $57 \%$ slicujeva. U grupama u $14 \%$, a mi ješano u $29 \%$ slučajeva.

$$
\text { OSNOVNI TIP: VI-a-2. }
$$

SUME SMREE I BIJELOG BORA NA DOLOMITNOJ RENDZINI
a) orografskekarakteristike
Prosječna nadmorska visina: $1.207 \mathrm{~m}, \mathrm{~g}= \pm 2 \%, \mathrm{~s}= \pm 80 \mathrm{~m}$
Prosjecna inklinacija: $12^{\circ}, g= \pm 20 \%, s= \pm 6,8^{\circ}$
Ekspozicija: $S=1, I=5, J=11, Z=15, R=0$ krugova. 


\section{b) Z e m 1 j is t a}

Maticna podloga: Uglaynom se ovaj tip zemljista obrazuje na saharoidnim dolomitima.

Svojstva zemljista: Povrsinska kamenitost izostaje ili je vrlo malena, bez znatnih pojava erozije, ukoliko nije znacajnije poremecen sklop sastojine, kada moze da nastupi porrsinska erozija srednjeg interim ziteta.

Cesta je pojava sirovog humusa debljine do $3 \mathrm{~cm}$, a humusno-akumulativni horizont je obiéno $25 \mathrm{~cm}$ moćan sa prelaskom u AC debljine uko $10 \mathrm{~cm}$. lako je humusno-akumulativni horizont plitak ovo su dublja zemljista, posto je dolomit rastrosen i fizioloski aktivan.

Skeletnost je slaba do srednja, a po mehanickom sastavu suilavace pjeskovite do glinovite, srednje izrazene stabilne zrnatestrukture. Ovo su karbonatna zemljista, alkalne reakcije, slabo snabdjevene sakalijumom i fosfors.:.

Zbog lakseg mehaničkog sastava ova zemljista su slabo obezbiedjena biljci pristupačnom vodom $i$ radi toga su to kserotenna stillis:s. Velika su kolebanja stanja vlaznosti u povrsinskom dijelu profila,\$to oteżava prirodnu obnovu ovih šuma.

c) Vegetacijskekarakteristike

Sastav drveca: pored bijelog bora i smrce javlja se jela pojedinačno, rjedje grupimično, jasika je sasvim rijetka.

Sastav grmlja: Juniperus communia, Daphne mezeroum, Lonioura xylosteum.

Sastav prizemne flore: Aremonia agrymonioidco, Aacumun europaeun, Euphorbia anygdaloides, Sanicula europaea, Mycelio muralia, Thymus aerpyllum, Buphtalmum salicifolium, Doricnium gexmanioum, te mahovine iz rodova: Hylooomium, Dicranum, Hypnum, Polytrichum, Pleurazium. 
d) Produkcione karakteristike

Vrste drveca i omjer smjese: smrča 0,49; bijeli bor 0,50; bukva s ostalim liscarima 0,01 .

Bonitetni razred stanista : smrëa III,9; bijeli bor III,9.

Zastrtost tla krosnjama $: 0,64 ; g= \pm 11 \% ; s= \pm 0,19$.

\begin{tabular}{|c|c|c|c|}
\hline Drvna zaliha & $\left(m^{3} / h a\right)$ & Godisnji zapreminski prira & $\left(m^{3} / h a\right)$ \\
\hline smrca & 105,2 & smrla & 3,84 \\
\hline bijeli bor & 106,3 & bijeli bor & 3,16 \\
\hline bukva s ost. 1 is. & 1,1 & bukva s ostalim liscarima & 0,07 \\
\hline ukupno & 212,6 & ukupno & 7,07 \\
\hline
\end{tabular}

PROCENTUALNA DEBLUINSKA STRUKTURA ZALIHE

\begin{tabular}{lrrrrrrr}
$\begin{array}{r}\text { Debljinska klasa } \\
\text { (cm) }\end{array}$ & $5-9,9$ & $10-$ & $20-$ & $30-$ & $50-$ & 80 i \\
Smría & 1,7 & 21,2 & 32,8 & 34,8 & 8,3 & 1,2 & 100,0 \\
Bijeli bor & 3,8 & 18,4 & 38,5 & 38,1 & 1,2 & - & 100,0 \\
Bukva sostalim lišc. & - & 100,0 & - & - & - & - & 100,0 \\
Sve vrste drveca skupa & 2,7 & 20,2 & 35,5 & 36,3 & 4,7 & 0,6 & 100,0 \\
\hline
\end{tabular}

KVALITETNA STRUKTURA ZALIHE ( $(u)$

\begin{tabular}{lrrrrr}
\hline Tehnizka kvalitetna klasa: & 1 & 2. & 3 & 4. & Ukupno \\
\hline Smrča & 49,8 & 33,7 & 14,8 & 1,7 & 100,0 \\
Bijeli bor & 58,3 & 23,7 & 16,3 & 1,7 & 100,0 \\
Bukva s ostalim 115̌carima & 100,0 & - & - & - & 100,0 \\
\hline Sve vrste drveća skupa & 54,3 & 28,5 & 15,5 & 1,7 & 100,0 \\
\hline
\end{tabular}


BROJ BILJAKA PODMLATKA POHA (Komada)

\begin{tabular}{|c|c|c|c|c|}
\hline Vrsta drveta & $\begin{array}{l}\text { Visine } \\
10-50 \mathrm{~cm}\end{array}$ & $\begin{array}{l}\text { Visine } \\
50-130 \mathrm{~cm}\end{array}$ & $\begin{array}{c}\text { Debl jine } \\
0.5 \mathrm{~cm} \text { na } 1.3 \mathrm{~m}\end{array}$ & Ukupno \\
\hline Jela & 203 & - & - & 203 \\
\hline Smrza & 3.047 & 491 & 415 & 3.953 \\
\hline Bijeli bor & - & 246 & 69 & 315 \\
\hline Bukva & 203 & - & 207 & 410 \\
\hline Ukupno & 3.453 & 737 & 691 & 4.881 \\
\hline
\end{tabular}

Omjer smjese po broju biljaka podmlatka: jela 0,04 : smrca 0,81 ; bijeli bor 0.07 ; bukva 0,08 .

Zastarčeno je $54 \%$, a oštećeno $8 \%$ od ukupnog broja biljaka podmlatka. Podmladak se javio pojedinačno rasporedjen u $46 \%$ slučajeva. U grupama u $8 \%$, a 11 ješano $46 \%$ slučajeva.

Portik se javio na $62 \%$ pcloženih krugova.

OSNOVNI TIP: VI -a-3

SUME SMRCE I BIJELOG BORA NA PLITKOM KALKOKAMBISOLU

a) 0 rog a f skek arakteristike

Prosječna nadmorska visina: $1.210 \mathrm{~m}, \mathrm{~g}= \pm 6 \%, \mathrm{~s}= \pm 123 \mathrm{~m}$

Prosječna inklinacija: $10^{\circ}, 9= \pm 45 \%, s= \pm 7,1^{\circ}$

Ekspozicija: $S=1, I=5, J=6, Z=1, R=0$ krugova.

b) $z$ em $\mid j i \xi t e$

Maticna podloga: uglavnom preovladavaju jedri kreźnjaci, a rjedje se mogu sresti $i$ dolonitizirani kreznjaci.

Svojstva zemijista: Pouršinska kamenitost je srednja, aerozija je rijetka poursinska slabog do srednjeg intenziteta. 
Dubina profila je ispod $40 \mathrm{~cm}$, izuzev pukotina. Sirovi humus je cest $i$ (može da) dostize debljinu u rijetkim slucajevima $i$ do $6 \mathrm{~cm}$. U prosjeku iznosi oko $3 \mathrm{~cm}$. Humusno-akumulativni horizont ne prelazi mocnost od $15 \mathrm{~cm}$. Cesto je erodiran i vrlo plitak, jedva primijetan. Po skeletnosti ovo su srednje do jako skeletna zemljista, glinovita ili ilovasta pomehanickom sastavu, u povrsinskom horizontu zrnaste, a u kambičnom poliedrične strukture dobro izražena.

Po hemijskim svojstrima ovo su kisela zemljista, slabo obezbijedjena sa fosforom, a srednje sa kalijumor.

Zbog plitkoce soluma ovo su kserotermna stanista, gdje se profil vrlo brzo isušuje i lako zagrijava radi sadrżaja skeleta.

c) Vegetacijskekarakteristike

Sastav drveca i grmlja: Bijeli bor i smrca su glavrie vrste, dck je jela manje zastupljena, a rijetko se susrece jasiks.

Sastav grmlja: Juniperus conmuris, Daphne mezereum, Lomiceri mingation.

Sastav prizemne flore: Aremonia agrimonioides, Euphorbia coriti daloides, Sanicula europaea, Asarmm europaetum, Mycelis muratis, Festin heterophylla; od mahovina vrste iz rodova: Dicranum, bylocomium, ifypriwn, Pl. urioriturt.

d) Produkcione karakteristike

Vrsta drveca $i$ omjer smjese: jela 0,19 ; smrča 0,36 ; bijeli bor 0.45 .

Bonitetni razred staništa : jela II,?; smréa II,8; bijeli bor 111,5 .

Zastrtost tla krošnjama $: 0,42 ; g= \pm 39 \% ; 5= \pm 0,27$. 
Drvna zalina $\left(m^{3} / \mathrm{ha}\right.$

jela

44.7

smrca

84,8

bijeli bor

106,3

ukupno

235,8

$g= \pm 44 \%, \quad s= \pm 171,8 \mathrm{~m}^{3}$
Godisnji zapreminski prirast $\left(m^{3} / \mathrm{ha}\right)$

jela

1,32

smrča

2,10

bijeli bor

1,53

ukupno $\quad 4,95$

$g=62 \%, s= \pm 5,03 \mathrm{~m}^{3}$

PROCENTUALNA DEBLJINSKA STRUKTURA ZALIHE

\begin{tabular}{|c|c|c|c|c|c|c|c|}
\hline $\begin{array}{c}\text { Debljinska klasa } \\
\text { (cm) }\end{array}$ & $5-9,9$ & $\begin{array}{l}10 \\
19,9\end{array}$ & $\begin{array}{l}20= \\
29,9\end{array}$ & $\begin{array}{l}30- \\
49,9\end{array}$ & $\begin{array}{l}50- \\
79,9\end{array}$ & $\begin{array}{l}30 i \\
\text { više }\end{array}$ & Ukupno \\
\hline Jela & 0,9 & 10,2 & 20,6 & 68,3 & - & - & 100,0 \\
\hline Smrča & 10,7 & 26,7 & 10,9 & 47,3 & 4,4 & - & 100,0 \\
\hline Bijeli bor & 2,2 & 2,2 & 19,5 & 64,7 & 11,4 & - & 100,0 \\
\hline Sve vrste drveca skupa & 5,0 & 12,6 & 16,6 & 59,1 & 6,7 & - & 100,0 \\
\hline
\end{tabular}

KVAL.ITETNA STRUKTURA ZALIHE. ( $u \%)$

\begin{tabular}{lrrrrr}
\hline Tehnicka kvalitetna klasa: & 1. & 2. & 3. & 4. & Ukupno \\
\hline Jela & 73,8 & 0,9 & 25,3 & - & 100,0 \\
Smrča & 60,6 & 13,7 & 24,4 & 1,3 & 100,0 \\
Bijeli bor & 53,5 & 42,1 & 4,4 & - & 100,0 \\
\hline Sve vrste drveca skupa & 59,9 & 24,1 & 15,5 & 0,5 & 100,0 \\
\hline
\end{tabular}

BROJ BILJAKA PODMLATKA PO HA (komada)

\begin{tabular}{lccccc} 
& Vrsta drveta & $\begin{array}{c}\text { Visine } \\
10-50 \mathrm{~cm}\end{array}$ & $\begin{array}{c}\text { Visine } \\
50-130 \mathrm{~cm}\end{array}$ & $\begin{array}{c}\text { Debljine } \\
0-5 \mathrm{~cm} \text { na } 1,3 \mathrm{~m}\end{array}$ & Ukupno \\
\hline Jela & 1.500 & - & - & 1.500 \\
SmrEa & - & - & 308 & 308 \\
\hline Ukupno & 1.500 & - & 308 & 1.808 \\
\hline
\end{tabular}


Omjer smjese po broju biljaka podmlatka: jela 0,83 ; smrča 0,17 .

Podmladak nije zastarčen. Oకteceno je 33: od ukupnag broja biljaka podmlatka.

Podmladak se javio pojedinačno rasporedjen 467 slućajeva, $u$ grupama se nije javljao, dok se miješano javio u $33^{*}$ slućajeva.

Ponik se javio na $85 \%$ položenin krugova.

OSNOVNI TIP: VI $-a-4$

SUME SMRCE I BIJELOG BORA NA DUBOKOM KALKOKAMBISOLU

a) 0 rografskekarakteristike

Prosječna nadmorska visina: $1.221 \mathrm{~m}, g= \pm 6,3 \%, s= \pm 164 \mathrm{~m}$

Prosječna inklinacija: $10^{\circ}, g= \pm 26,1 \%, s= \pm 5,5^{\circ}$

Ekspozicija: $S=3, I=3, J=9, Z=3, R=0$ krugova.

b) $z e m$ l j is $t e$

Matična podloga: Osnovna matična podloga su jedri krečnjaci, a rjedje serija krečnjaka i rožnjaka.

Svojstva zemljišta: Površinska kamenitost je srednja do visoka, sa slabim i rijetkim pojavama znakova erozijo.

Dubina profila iznosi preko $50 \mathrm{~cm}$, a u zasticenim mjestima i pukotinama prelazi $i$ preko $1 \mathrm{~m}$. Javljaju se na blażim nagibima ne preiazeći nagibe of $15^{\circ}$.

Imaju razvijen $i$ organični horizont od $2-4 \mathrm{~cm}$ (sirovi humus) a humusno-akumulativni horizont dostiže debljinu $i$ do $15 \mathrm{~cm}$, ukoliko prethodno nije erodiran.

Srednje je skeletan, glinovit do ilovast pomehaničkon sastavu, zrnate strukture u humusno-akumulativnom horizontu, a u kambicnom poliedrične dobro izražene.

Kisele su reakcije, srednje obezbjedjen sa kalijumon, a slabo sa fosforial. 
Thos donre arotere strukture i dubine solumd ugianom si as zem!jisto povolinin vodnowazdughih swojstava

r) Veqetacijskekarakter;stike

Sastav drveca: uz bijeli bor i smrcu, jela je cesca. dis je bukua sasvim rijetka.

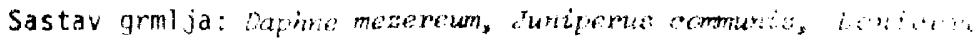
rytosteum, sonbus areupuria.

Sastav prizeme flore: Pteridium aguilium, fou otgria, Fu,

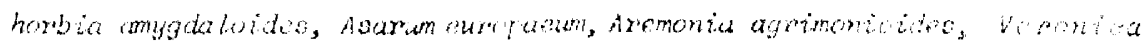

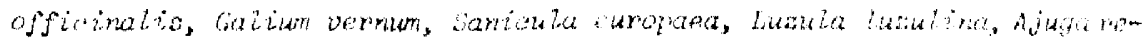

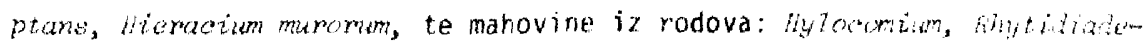
lphus, Hypnum, Pleurozizm.

d) Produkcionekarakteristike

Vrsta drveca i omjer smjese: jela 0,09 ; smrca 0,45 ; bijeli bor 0,46 .

Bonitetni razred staništa : smrča III,1; bijeli bor 11,7 .

Zastrtost tla krośnjana $: 0,62, g= \pm 18,2 \%, s= \pm 0,23$.

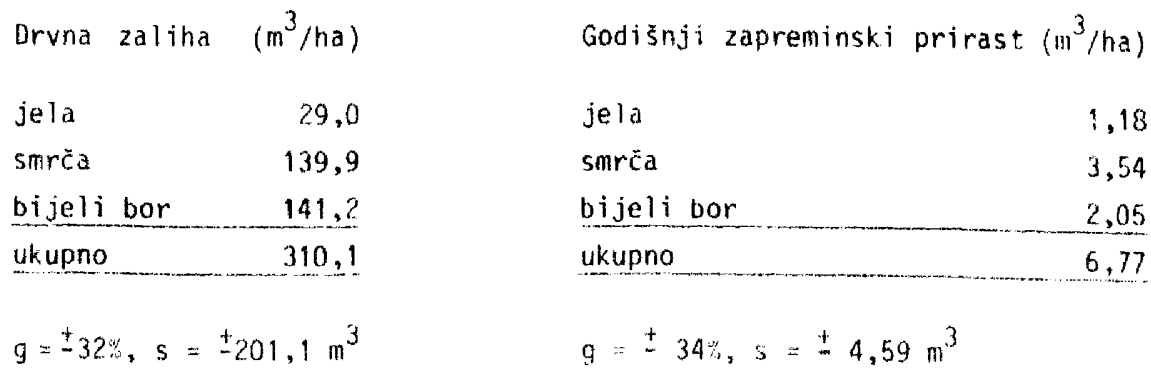




\begin{tabular}{|c|c|c|c|c|c|c|c|}
\hline $\begin{array}{c}\text { Debljinska klasa } \\
\text { (cm) }\end{array}$ & $5-9,9$ & $\begin{array}{l}10 \\
19,9\end{array}$ & $\begin{array}{l}20- \\
29,9\end{array}$ & $\begin{array}{l}30- \\
49,9\end{array}$ & $\begin{array}{l}50 \\
79,9\end{array}$ & $\begin{array}{l}80 i \\
v i s e\end{array}$ & Ukupno \\
\hline Jela & 3,8 & - & 20,3 & 75,9 & - & - & 100,0 \\
\hline Smrěa & - & 10,7 & 13,5 & 52,6 & $23, ?$ & .. & 100,0 \\
\hline Bijeli bor & $\therefore$ & 2,1 & 16,0 & 71,2 & 10,7 & $\therefore$ & 100,0 \\
\hline Sve vrste drveca skupa & 0,4 & 5,8 & 15,3 & 63.2 & 15,3 & - & 100,0 \\
\hline
\end{tabular}

KVAL.ITETNA STRUKTURA ZALIHE ( $u \%)$

\begin{tabular}{|c|c|c|c|c|c|}
\hline Tehnicka kvalitetna klasa: & 1. & 2. & 3. & 4. & ikupno \\
\hline ieta & 50,6 & 49,2 & - & - & 100,0 \\
\hline Smrča & 46,8 & 39,2 & 11,4 & 2,6 & 100,0 \\
\hline Bijeli bor & 90,0 & 6,3 & 3.7 & - & 100,0 \\
\hline Sve vrste drveca skupa & 66,8 & 25,2 & 6,8 & 1,2 & 100,0 \\
\hline
\end{tabular}

\section{BROJ BIL JAKA POOMLATKA POKA (Komada)}

\begin{tabular}{|c|c|c|c|c|}
\hline Vrsta drveta & $\begin{array}{l}\text { Visine } \\
10-50 \mathrm{~cm}\end{array}$ & $\begin{array}{c}\text { Visine } \\
50-130 \mathrm{~cm}\end{array}$ & $\begin{array}{c}\text { Debljine } \\
0-5 \mathrm{~cm} \text { na } 1,3 \mathrm{~m}\end{array}$ & Ukupno \\
\hline Jela & 2.889 & 874 & 468 & 4.231 \\
\hline Surcáa & 361 & - & - & 361 \\
\hline Bijeli bor & - & - & 111 & 111 \\
\hline Ostali liscari & 361 & - & 123 & 484 \\
\hline Ukupno & 3.611 & 874 & 702 & 5.187 \\
\hline
\end{tabular}

Onjer smjese po broju biljaka podmlatka: jela 0,32; smrča 0,07; bijeli bor 0,02; ostali liscari 0,09 .

lastarceno je $12 \%$, a osteceno $38 \%$ od ukupnog brojabiljaka podmiatka.

Podmladak se javljao jednolicno rasporedjen u $38 \%$ slucajeva, $u$

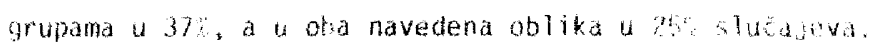


Ponik (biljcice do $10 \mathrm{~cm}$ visine) javio se na $50^{*}$ polazenih primjernih krugova

OSNOVNI TIP: VI-a-5

SUME SMRCE I BIJELOG BORA NA LUVISOLU NA KRECNJAKU

a) 0 rografske $k$ a $r a k t e r i s t i k \notin$

Prosječna nadmorska visina: $1.208 \mathrm{~m}, \mathrm{~g}= \pm 11,5= \pm 217 \mathrm{n}$

Prosjecna inklinacija: $5^{\circ}, g= \pm 45, s= \pm 3.9^{\circ}$

Ekspozicija: $S=2, I=3, J=7, Z=1, R=0$ krugova.

b) 2 e $\ln l i s t a$

Matiéna podloga su uglavnom jedri krećnjaci, a razvija se samo na površinama koje su zaravmjene ili slabo nagnutih reljefskih oblika.

Svojstva zemljišta: Površinska kamenitost je srednja do malena, bez pojave znakova površinske erozije.

Skeletnost profila je slaba do srednja, a po mehanickom sastavu su površinski horizonti ilovače, a dublji glinovite ilovače do glinuse. Struktura je izražena,poliedrična,dobra, a posebno u dubljim dijelovima soluma.

Sirovi humus je zastupljen, do $2 \mathrm{~cm}$ debljine, a humusno-akumulativni do $8 \mathrm{~cm}$. Debljina eluvijalnog horizonta se krece od $15-25 \mathrm{~cm}$. Ovo su duboka zemljišta dobrih vodno-vazdušnih svojstava.

c) Vegetacijskekarakteristike

Sastav drveca i grmlja: Uz bijeli bor i smrét zastupljena jes manjim stepenom učěca i jela, dok je bukva vrlo rijetka.

Sastav grm1ja: Juniperus communia, roniceru sulooteum, Daphne maseriatr.

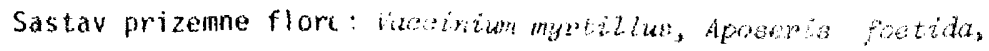

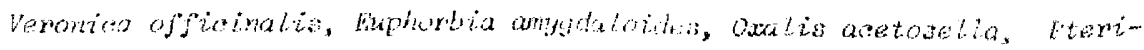

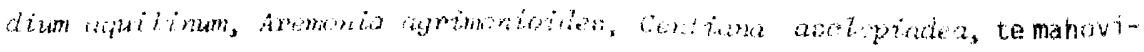

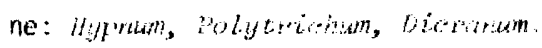




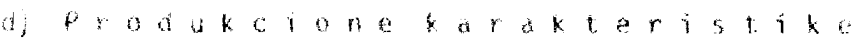

Vrsta arveca i omjer smjese: jela u tragovima, smrea o, be bijuli bor 0,32 .

Bonitetni razred stanista : smrca 111.0; bijeli bor 1 1.5.

tastrtost tla krosnjama $: 0,35 ; 9: \pm 41,5: \pm 0,23$.

\begin{tabular}{|c|c|c|c|}
\hline Druna zaliha & $\left(m^{3} / h a\right)$ & Codisnji zapreminski $p$ & prinast $\left(\mathrm{m}^{3} / \mathrm{ha}\right)$ \\
\hline jela & 0,9 & jela & 0,01 \\
\hline $\operatorname{smr} c \breve{a}$ & 217,7 & smrča & 2,30 \\
\hline bijeli bor & 101,9 & bijeli bor & 0,65 \\
\hline ukupno & 320,5 & ukupno & 2,96 \\
\hline
\end{tabular}

PROCENTUALNA DEBLJINSKA STRUKTURA ZAL. HIE

\begin{tabular}{|c|c|c|c|c|c|c|c|}
\hline $\begin{array}{c}\text { Debljinska klasa } \\
(\mathrm{cm})\end{array}$ & $5-9,9$ & $\begin{array}{l}10 \\
19,9\end{array}$ & $\begin{array}{l}20- \\
29,9\end{array}$ & $\begin{array}{l}30- \\
49,9\end{array}$ & $\begin{array}{l}50 \\
79,9\end{array}$ & $\begin{array}{l}80 \text { i } \\
\text { više }\end{array}$ & Ukupno \\
\hline Jela & 100,0 & .. & - & - & - & - & 100,0 \\
\hline Simržâ & 0,7 & 12,1 & 30,6 & 52,4 & 4,2 & - & 100,0 \\
\hline Bijeli nor & - & - & 16,4 & 73,1 & 10,5 & - & 100,0 \\
\hline Sve vrsta drveca skupa & 0,8 & 8,2 & 26,0 & 58,8 & 6,2 & - & 100,0 \\
\hline
\end{tabular}

KVALITETNA STRUKTURA ZALIHE ( $u$ \%)

$\begin{array}{lrrrrr}\text { Tehnicka kvalitetna klasa: } & 1 & 2 & 3 & 4 & \text { Ukupno } \\ \text { Jela } & 100,0 & - & & - & 100,0 \\ \text { Smrca } & 59,1 & 28,4 & 11,8 & 0,7 & 100,0 \\ \text { Bijeli bor } & 51,8 & 31,8 & 16,4 & -100,0 \\ \text { Sve vrste drveca skupa } & 56,9 & 29,4 & 13,2 & 0,5 & 100,0\end{array}$




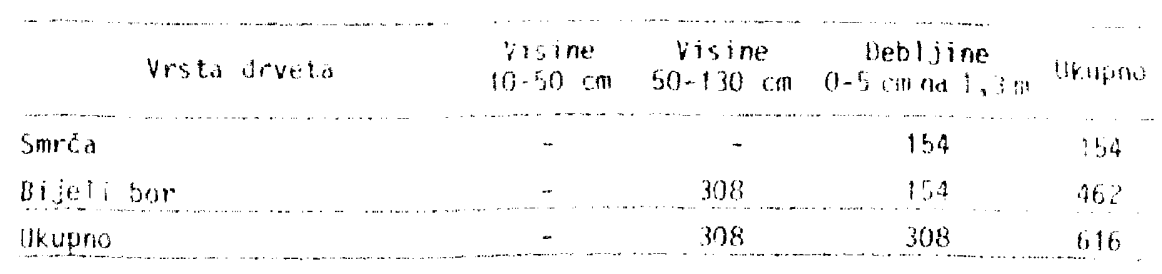

Omjer smjese po broju biljaka podmlatka: smrća 0,25 ; bijelibor 0.75

Podmladak nije zastarcen niti ostecen. Jav'jao se istovremeno i u grupama i pojedinacno.

\section{OSNOVNT TIP: VI -a-7}

SUME SMRCE I BIJELOG BORA NA DUBOKOM DISTRICNOM KAMBISOLU

a) orografskek a $\mathrm{k}$ akteristike

Prosječna nadmorska visina: $1.009 \mathrm{~m}, \mathrm{~g}= \pm 6, \mathrm{~s}= \pm 169 \mathrm{~m}$

Prosjecna inklinacija: $18^{\circ}, \mathrm{g}= \pm 18 \%, \mathrm{~s}= \pm 8,6^{\circ}$

Ekspozicija: $S=2, I=7, J=11, Z=8, R=0$ krugova.

b) $z e m i j i s t e$

Matična podloga: Może da bude verfenski sedimenti (pjesçari i glinci), silikatne brece, rożnjaci, kvarc porfiri, kvarcni pješčari kao i serije izgradjene iz članova: laporca, pješcara, konglomerata i laporovitin krečjaka (jurski fliš).

Svojstva zemljista: Poyršine pod ovim tipom zemijišta su skoro bez povrsinske kamenitosti, sa slabo izrażenom poursinskom erozijon samo na vecim nagibima terena.

Dubina fizioloski aktivnog profila prelazi i jedan metar, sa slabom do sreonje izrażenom skeletnošcu soluma. Po mehanickom sastavu ovo su heterogena amlista od djeskovitih do glinovitih ilovaca. Sirovi humus muze da bude deben $i$ dn 5 cm, a humusno akumulativni u prosjeku iz 
nosi 5 m, ohrienog tipa, rjedje dostize nocnost do 17 in

Ovo su kisela zem)jista, nepovoljnin hemijskih svojstava, sto se djelomicno kompenzira velikom dubinom soluma i povoljnim vodncimazdusnim osobinama.

c) Vegetacijskekarakteristike

Sastav drveca: Uz smič i bijeli bor cesce su zastupljente jeio (u odmaklijim fazama razvoja), zatim divlja kruška, divlja jabuka,divija trešnja, bukva, gorski javor, jasika, breza, jarebika, obicni jrab.

Sastav grmlja: Smreka (eimiperus ammmis), predstavlja najzastupljeniju vrstu medju brojnim vrstama grmija - Corylus abliana, i, a-

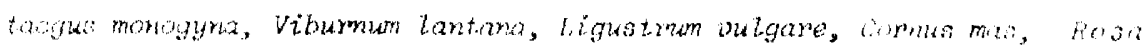

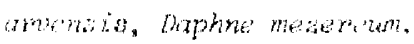

Sastav prizemne flore: Veliku pokrovnost prizemne rore cine brojne vrste, medju kojima su zastupljenije: Ptemidiam aquizimu, Brain.polizm pinratum, Vacoiniwn myrtillus, festuoa montana, Fragaria vesca, Savimla europaea, sesteria autumatis, Primula vulgaris, salviaglutinosa, Euphorbia amyglatoides, Anemonia agrimonioides, Melamylmum situaticum, Galium rotundifolium, Luzula vrste. Dosta su zastupl jene mahovine iz. rodova: Polytrichum, Dioranum, te Pleuroaium schreberi., Leucobryum clauatw.

d) Produkcionekarakteristike

Vrsta drveca $i$ omjer smjese: jela 0,01 ; smrča 0,50 ; bijeli bor 0,46 ; bukva 0,03 .

Bonitetni razred staništa : smrč 11,8 ; bijeli bor 11,2 .

Zastrtost tla krosnjama $\quad: 0,68 ; 9= \pm 12 \%, s= \pm 0,21$.

$\begin{array}{lrlr}\text { Druna zaliha }\left(\mathrm{m}^{3} / \text { ha }\right) & \text { Godišnj zapreminski prirast }\left(\mathrm{m}^{3} / \mathrm{ha}\right) \\ \text { jela } & 3,6 & \text { jela } & 0,21 \\ \text { smrča } & 184,4 & \text { smrća } & 7,21\end{array}$




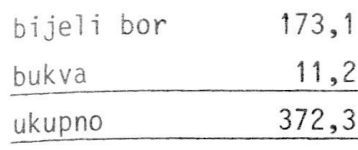

\begin{tabular}{lr} 
bijeli bor & 4,75 \\
bukva & 0,18 \\
\hline ukupno & 12,35 \\
\hline
\end{tabular}

$g=-23 \%, s= \pm 218,2 \mathrm{~m}^{3}$

$$
g= \pm 22 \%, s= \pm 6,98 \mathrm{~m}^{3}
$$

PROCENTUALNA DEBLUINSKA STRUKTURA ZALIHE

\begin{tabular}{lrrrrrrrr}
\hline \multicolumn{1}{r}{$\begin{array}{c}\text { Debijinska klasa } \\
(\mathrm{cm})\end{array}$} & $5-9,9$ & $10, \overline{9}$ & $20-\overline{9}$ & $30-$ & $50-$ & 80 i & Ukupno \\
\hline Jela & - & 40,6 & - & 59,4 & - & - & 100,0 \\
Smrča & 4,5 & 9,8 & 26,2 & 52,4 & 7,1 & - & 100,0 \\
Bijeli bor & 0,5 & 12,8 & 18,4 & 61,3 & 7,0 & - & 100,0 \\
Bukva & - & 8,6 & 27,1 & 52,2 & 12,1 & - & 100,0 \\
\hline Sve vrste drveća skupa & 2,5 & 11,5 & 22,3 & 56,6 & 7,1 & - & 100,0 \\
\hline
\end{tabular}

KVAL ITETNA STRUKTURA ZALIHE $(u \%)$

\begin{tabular}{lrrrrrr}
\hline \multicolumn{1}{r}{ Tehnička kvalitetna klasa: } & \multicolumn{1}{c}{1.} & \multicolumn{1}{c}{ 2. } & \multicolumn{1}{c}{ 3. } & 4. & Ukupno \\
\hline Jela & 40,6 & 59,4 & - & - & 100,0 \\
Smrča & 52,5 & 40,3 & 5,0 & 2,2 & 100,0 \\
Bijeli bor & 79,9 & 12,2 & 7,9 & - & 100,0 \\
Bukva & - & 20,7 & 27,1 & 52,2 & 100,0 \\
\hline Sve vrste drveća skupa & 63,5 & 26,8 & 7,0 & 2,7 & 100,0 \\
\hline
\end{tabular}

BROJ BILJAKA PODMLATKA PO HA (komada)

\begin{tabular}{lrrrrr} 
& Vrsta drveta & Visine & Visine & Debljine & Ukupno \\
\hline Jela & $10-50 \mathrm{~cm}$ & $50-130 \mathrm{~cm}$ & $0-5 \mathrm{~cm}$ na $1,3 \mathrm{~m}$ & Ukun \\
Smrča & 696 & 140 & 316 & 1.152 \\
Bijeli bor & 4.196 & 2.259 & 624 & 7.079 \\
Bukva & - & - & 71 & 71 \\
Javar gorski & 696 & 847 & - & 1.543 \\
Grab obični & - & 140 & - & 140 \\
Ukupno & 464 & - & - & 464 \\
\hline
\end{tabular}




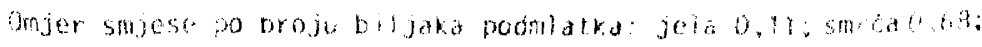

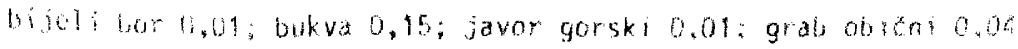

7astarceno je 20*, a osteceno 15: od ukupnog trofabiriakapodintatro

Podmladak je bio jednoticno pojedinačno rasporedjen is slucajeva U grupama se javio w 10' slucajeva, a mijesano u 55 slutajeva. Ponk je registrovan na 46 . polozenih krugova.

\section{B. SUME JELE I SMRCE}

OSNOVAR TIP: VI-D) I

SUME JELE I SMRCE HA KALKOMELANOSULS

a) 0 rografske karakteri: i i k e

Prosječna nadmorska visina: $1.205 \mathrm{~m}, \mathrm{~g}= \pm 4 \%, \mathrm{~s}= \pm 165 \mathrm{~m}$

Prosječna inklinacija: $14^{\circ}, g= \pm 15, s= \pm 7,1^{\circ}$

Ekspozicija: $S=21, I=8, Z=7, R=1$ krug.

b) 2 em j j s

Matična podloga: Najčešce se javljaju jedri krečnjaci a sasvim rijetko bitumenozni krečnjaci ili serija krečnjaka sa rožnjacima.

Svojstva zemljišta: Površinska kamenitost ovih zemljišta jevrlo visoka, iako se javlja uglavnom na većin inklinacijama nije izrażena erozija, ili ako je, onda slaba površinska.

Dubina fizioloski aktivnog profila u prosjeku iznosi oko 25-30 $\mathrm{cm}$, a rjedje dostiže dubinu do $40 \mathrm{~cm}$. Profil je jako skeletan, po mehaničkom sastavu, preovladavaju ilovače. a strukture je najcesce zrnaste, srednje do vrlo stabilne.

Preovladavaju organomineralni kalkomelanosoli nad organogenim, a organični horizont, kada se obrazuje, ima debljinu oko $3 \mathrm{~cm}$.

Smanjena produktivnost. ovih starista je uslovijena uglavnom pitkocom soluma $i$ siabom obezbjedjenosti sa biljci pristupacrom vodom, što potencira veliki sadržaj skeleta. 
Sastav deveca: Uz edifikatore jelu i smrcu, cesce je primijesana jarebika, rjedje gorski javor, bukva i bijeli bor.

Sastav grmlja: Medju brojnim vrstama grmlja zastupljenije su:

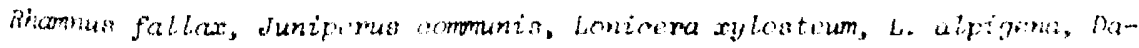
pine meiserioun.

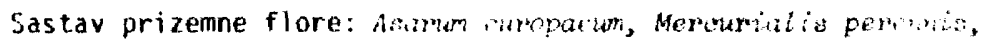

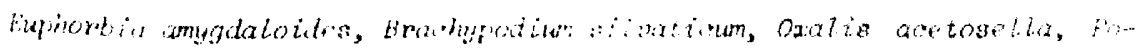

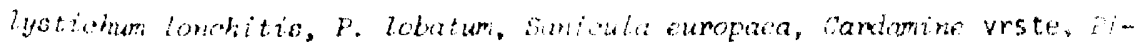
rola vrste i druge.

d) Produkcionekarakteristike

Vrste drveca $i$ omjer smjese: jela 0,53 , smrca 0,44 , bijeli bor manje od 0,01 , bukva $i$ ostali liscari 0,03 .

Bonitetni razred staniśta : jela 11,8 ; smrča 111,4 .

Lastrtost tla krosinjama $\quad: 0,65, g= \pm 12, s= \pm 0,26$.

\begin{tabular}{|c|c|c|c|}
\hline Drvna zaliha & $\left(m^{3} / h a\right)$ & Godišnji zapreminski prir & $\left(m^{3} / \mathrm{ha}\right)$ \\
\hline jela & 190,0 & jela & 3,79 \\
\hline $\begin{array}{l}\text { smrca s bijelim } \\
\text { borom }\end{array}$ & 159,0 & smrća s bijelim borom & 3,32 \\
\hline $\begin{array}{l}\text { bukva s ostalim } \\
\text { liścarima }\end{array}$ & 9,0 & bukvas ostalim liscarima & 0.16 \\
\hline ukupno & 358,0 & ukupno & 7.27 \\
\hline
\end{tabular}

PROCENTUALNA DEBLUINSKA STRUKTURA ZAL IHE

\begin{tabular}{|c|c|c|c|c|c|c|c|}
\hline $\begin{array}{l}\text { Debljinska klasa } \\
(\mathrm{cm})\end{array}$ & $5-9,9$ & $\begin{array}{l}10- \\
19,9\end{array}$ & $\begin{array}{l}20 \\
29,9\end{array}$ & $30-$ & $\begin{array}{l}50- \\
79,9\end{array}$ & $\begin{array}{l}80 i \\
v i s e\end{array}$ & 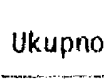 \\
\hline Jela & $1, !$ & 3,7 & 14,0 & 48,9 & 28,2 & 3.7 & 100,0 \\
\hline Smréa s bijelim borom & 1, & 5,6 & 14,5 & 62,0 & 16.3 & - & 100,0 \\
\hline Bukva sost. liscarina & $?, ?$ & $\ldots$ & $\therefore$ & 81,7 & 16,1 & $\ldots$ & 100,0 \\
\hline Sve vrste drveca skupa & 1,6 & 4.4 & 13,9 & 55,5 & 22,6 & $\therefore, 0$ & 100,0 \\
\hline
\end{tabular}


VVALITETNA STRUKTURA ZALIHE ( $u \%)$

\begin{tabular}{lrrrrr}
$\quad$ lehnicka kvalitetna klasa: & 1. & 2. & 3, & 4 & Ukupno \\
Jela & 53,6 & 34,9 & 9,9 & 1,6 & 100,0 \\
Smrća s bijelim borom & 27,5 & 41,7 & 26,8 & 4,0 & 100,0 \\
Bukvas ostalim liscarima & - & 39,7 & 41,9 & 18,4 & 100,0 \\
\hline Sve vrste drveca skupa & 40,7 & 38,0 & 18,2 & 3,1 & 100,0 \\
\hline
\end{tabular}

$$
\text { BROJ BIL JAKA PODMLATKA PO HA (KOMada) }
$$

\begin{tabular}{|c|c|c|c|c|}
\hline Vrsta drveta & $\begin{array}{l}\text { Visine } \\
10-50 \mathrm{~cm}\end{array}$ & $\begin{array}{l}\text { Visine } \\
50-130 \mathrm{~cm}\end{array}$ & $\begin{array}{c}\text { Debljine } \\
0-5 \mathrm{~cm} \text { na } 1,3 \mathrm{~m}\end{array}$ & Ukupno \\
\hline Jela & 1.356 & 178 & 378 & 1.912 \\
\hline Smrca & 7.133 & 622 & 133 & 7.888 \\
\hline Javor gorski & - & 89 & 89 & 178 \\
\hline Ukupno & 8.489 & 889 & 600 & 9.978 \\
\hline
\end{tabular}

Omjer smjese po broju biljaka podmlatka: jela 0,19 , smrca 0,79 , javor gorski 0,02 .

Zastarčeno je $41 \%$, a ošteceno $12 \%$ od ukupnog brojabiljaka podmlatka.

Pojedinačno rasporedjen podmladak javio se u $53 \%$ slučajeva, u grupama u 35\%, a miješano u $12 \%$ slučajeva.

Ponik se javio na $51 \%$ položenih krugova.

$$
\text { OSNOVNI TIP: VI -b-2 }
$$

SUME JELE I SMREE NA PLITKOM KALKOKAMBISOLU

a) $0 r \circ g r a f s k e k a r a k t e r i s t i k e$

Prosjecna nadmorska visina: $1.240 \mathrm{~m}, 9= \pm 4 \%, 5= \pm 163 \mathrm{~m}$

Prosječna inklinacija: $11^{\circ}, g= \pm 23 \%, s= \pm 7,5^{\circ}$

Ekspozicija: $s=16, I=9, j=7$ i $P:: 1 \mathrm{krug}$. 
Maticna podloga: Najzastupljeniji su jedri kreznjaci, a majese srecu dolomitizirani krecnjaci, dolomiti, brecasti krečnjaci i mermer.

Svojstva zemljista: Poursina pod ovim zenljistem, koje je pli. tko, je jako kamenita, sa slabo i rijetko izrazenim eruzionim procesima. Zemijisni profil je jako skeletar.

Urganicni horizont je debeo ako $2-3 \mathrm{~cm}$ (sirovi humus) ion moje da izostane. Humusno-3kumulativni je velo varijabilne mocnosti zbog loga, sto je cesto bio erodiran. Mjestimicno dolazi do sekundarnog obogocivanja sa organskom materijom, a gdje je ocuvan moze da bude i preko 15 c.m debeo.

Po meharickom sastavi su ilovace do glinovite ilovače. rjedje glinuše.

Radi plitkoce soluma i humusno-akumulativnog horizonta ova zemljista ne mogu da obezbijede dovoljne kolicine hranjivih elenenata i vode tokom cijele godine, te su ovo relativno suha $i$ kserotermna stanista.

c) Vegetacijskekarakteristike

Sastav drveca. Osim jele i smrce sporadicno su primijesane bukva, gorski javor, bijeli bor.

Sastav grmlja: Od vił̌e vrsta grmija cesce su: Rhammo fallar, Daphne mexereum, Lonicera xulosteum, $L$ alpigena, Juriperus communis.

Sastav prizemne flore: Euphorbia amygdaloides, Asarum curopaum, Aremonia agrimonioides, Sanioula europaea, Mercurialis perennis, cardamine vrste, Oxalis acetoselia, Asperula odorata, Salvia glutinosa, a od mahovina vrste roda Rhytidiadelphus, te pleurozium schreberi.

d) Produkcionekarakteristike

Vrste drveca i omjer smjese: jela 0,54 ; snurca 0,45 ; bijeli bor 5 bukvom 0,0 ?.

Bonitetni razred staništa : jela II,9, smrča 111,5 . Zastrtost tla krošnjama : 0,$57 ; \mathrm{g}= \pm 15 \%, \mathrm{~s}= \pm 0,26$. 


$\begin{array}{lrlr}\text { Orvna zalina } & \left(\mathrm{m}^{3} / \mathrm{ha}\right) & & \text { Godišnji zapreminski prirast }\left(\mathrm{m}^{3} / \mathrm{ha}\right) \\ \text { jela } & 171,2 & \text { jela } & 2,50 \\ \text { smrca } & 140,4 & \text { smrca } & 2,45 \\ \text { bijeli bor } & 1,3 & \text { bijeli bor } & 0,04 \\ \text { bukva } & 2,6 & \text { bukva } & 4,99 \\ \text { ukupno } & 315,5 & \text { ukupno } & \\ 9= \pm 21 \%, \mathrm{~s}= \pm 195,8 \mathrm{~m}^{3} & g= \pm 29 \%, \mathrm{~s}= \pm 4,26 \mathrm{~m}^{3} & \end{array}$

PROCENTUALNA DEBLJINSKA STRUKTURA ZAL IHE

\begin{tabular}{lrrrrrrrr}
$\begin{array}{c}\text { Debljinska klasa } \\
(\mathrm{cm})\end{array}$ & $5-9,9$ & $\begin{array}{r}10 \\
19,9\end{array}$ & $\begin{array}{l}20 \\
29,9\end{array}$ & $\begin{array}{l}30 \\
49,9\end{array}$ & $\begin{array}{l}50 \\
79,9\end{array}$ & $\begin{array}{l}80 i \\
\text { vise }\end{array}$ & Ukupno \\
\hline $\begin{array}{l}\text { Jela } \\
\text { Smiča }\end{array}$ & 1,4 & 12,1 & 16,7 & 54,9 & 14,9 & - & 100,0 \\
Bijeli bor & 1,3 & 5,3 & 26,1 & 47,0 & 18,8 & 1,5 & 100,0 \\
Bukva & - & - & - & - & 100,0 & - & 100,0 \\
Sve vrste drveca skupa & 1,4 & 8,9 & 20,7 & 51,5 & 16,8 & 0,7 & 100,0 \\
\hline
\end{tabular}

KVALITETNA STRUKTURA ZAL.IHE (u罗)

\begin{tabular}{lrrrrr}
\multicolumn{1}{c}{ Tehnicka kvalitetna klasa: } & 1. & 2. & 3. & 4. & Ukupno \\
\hline Jela & 42,5 & 36,4 & 16,2 & 4,9 & 100,0 \\
Sinrča & 42,9 & 34,7 & 19,7 & 2,7 & 100,0 \\
Bijeli bor & 100,0 & - & - & - & 100,0 \\
Bukva & - & - & 100,0 & - & 100,0 \\
Sve vrste drveca skupa & 42,6 & 35,1 & 18,4 & 3,9 & 100,0 \\
\hline
\end{tabular}

BROJ BILJAKA POOMLATKA PO HA (komada)

\begin{tabular}{lccccc} 
& Vrsta drveta & Visine & Visine & \multicolumn{2}{c}{ Debljine } \\
& $10-50 \mathrm{~cm}$ & $50-130 \mathrm{~cm}$ & $0-5 \mathrm{~cm}$ na $1.3 \mathrm{~m}$ & Ukupno \\
\hline Jela & 6.722 & 778 & 583 & 8.083 \\
Smrca & 750 & 56 & 167 & 973 \\
Bukva & 7.472 & 945 & 917 & 9.334 \\
\hline Ukupno & & & & 97 \\
\hline
\end{tabular}


Omjer sinjese po broju biljaka podmlatka: jela 0,87 , smrca 0,90 ; bukva 0.03 .

Zastarceno je 29 , a osteceno 21 i od ukupnog broja biljaka podiml a tka.

Podmladak se javljao pojedinačno rasporedjen $u 57$, u grupama 421 . a miješano u 22 : slućajeva.

Ponik se javio na $53^{\prime \prime}$ polozenih krugova.

OSNOVNI TIP: VI-b-3

EIIME JELEE I SMFCE NA DUBOKOM KALKOKAMB ISOLU

a) 0 rografskekarakteristike

Prosječna nadmorska visina: $1.133 \mathrm{~m}, g= \pm 4 \%, s= \pm 170 \mathrm{~m}$

Prosječna inklinacija: $12^{\circ}, g= \pm 17 \%, s= \pm 7,4^{\circ}$

Ekspozicija: $S=21, I=14, J=11, Z=10, R=0$ krugova.

b) $Z$ em $l j$ is $t a$

Matična podloga: preovladavaju jedri krečnjaci, zatim laporoviti i konglomeratični kreínjaci, rjedje dolomiti.

Svojstva zemljišta: Ovo su duboka zemljišta srednje do jake površinske kamenitosti sa vrlo slabo izraženom površinskom erozijom. Pojava sirovog humusa je evidentna, a njegova mocnost ne prelazi $4 \mathrm{~cm}$, cesto $i$. zostaje organičri horizont. Debljina humusno-akumulativnog horizonta je varijabilna, a u najočuvanijim slučajevima dostiže $i$ do $25 \mathrm{~cm}$.

Humusno-akumulativni norizont je po teksturi ilovast dobro izrażene zrnaste strukture, a kambični horizont je ilovača do glinovita ilovača dobro izražene poliedrične strukture. Skeletnost profila je srednja.

Ova zemljista su srednje obezbjedjena sa hranjivina a imaju dobre vodno-fizicke osobine, posebno na onim stanistima gdje je dubina soluma veca. 
c) Vegetacijskekarakteristike

Sastav drveca: Uz jelu i smrču rijetko su zastupljeni bukva, gorski javor, bijeli bor, gorski brijest.

Sastav grmlja: Medju brojnim vrstama zastupljenije su: Mhomraus

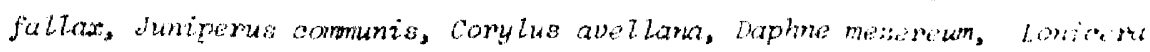
xylostenm, Crataegus monog!na.

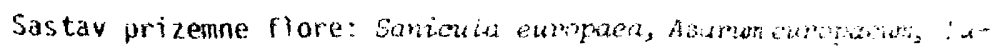

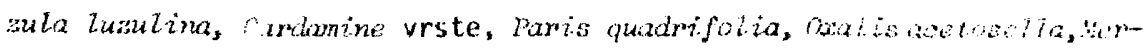

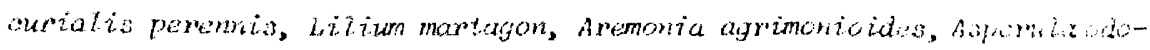
rata, Fatua at batica i brojne druge vrste. Mjestimicno su vece pokro-

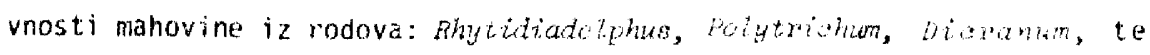
pleuroziam sehreberi.

d) Produkcione karakteristike

Vrsta drveca $i$ omjer smjese: jela 0,50 ; smrća 0,49 ; bijelibor. bukva i breza zajedno 0,01 .

Bonitetni razred staništa : jela II,6; smrča III,?.

Zastrtost tla krošnjama $: 0,69 ; 9: \pm 9 \%, s= \pm 0,24$

\begin{tabular}{|c|c|c|c|}
\hline Drvat zalina & $\left(m^{3} / h a\right)$ & Godisnji zapreminski & prirast $\left(m^{3} / h a\right)$ \\
\hline jela & 142,3 & jela & 3,98 \\
\hline $\begin{array}{l}\text { smrče i bijelog } \\
\text { bora }\end{array}$ & 138,0 & smrze i bijelog bora & 3,33 \\
\hline bukve i breze & 1,4 & bukve $i$ breze & 0,02 \\
\hline Ukupno & 281,7 & Ukupriu & 7,33 \\
\hline
\end{tabular}


PROCENTUALNA DEBLJINSKA STRUKTURA ZAL IHE.

\begin{tabular}{|c|c|c|c|c|c|c|c|}
\hline $\begin{array}{c}\text { Debljinska klasa } \\
(\mathrm{cm})\end{array}$ & $5-9,9$ & $\begin{array}{l}10= \\
19,9\end{array}$ & $\begin{array}{l}20 \\
29,9\end{array}$ & $\begin{array}{l}30- \\
49,9\end{array}$ & $\begin{array}{l}50- \\
79,9\end{array}$ & $\begin{array}{l}\text { Bo i } \\
\text { više }\end{array}$ & Ukupno \\
\hline Jeta & 0,9 & 6,8 & 17,0 & 54,9 & 19,0 & 1,4 & 100,0 \\
\hline Smrča sbijelim borom & 1,8 & 10,3 & 16,3 & 55,0 & 15,6 & 1,0 & 100,0 \\
\hline Bukvas brezom & - & 44,2 & $\therefore$ & - & 55,8 & - & 100,0 \\
\hline Sve vrste drveca skupa & $1 ; 3$ & 8,7 & 16,6 & 54,7 & 17,5 & 1,2 & 100,0 \\
\hline
\end{tabular}

KVALITEINA STRUKIURA ZALIHE (U\%)

\begin{tabular}{lrrrrr}
\hline Tehnička kvalitetna klasa: & 1 & 2. & 3 & 4. & Jkupno \\
\hline Jela & 43,6 & 41,7 & 10,5 & 4,2 & 100,0 \\
Smrča s bijelim borom & 37,8 & 44,8 & 12,5 & 4,9 & 100,0 \\
Bukva s brezom & - & - & 44,2 & 55,8 & 100,0 \\
\hline Sve vrste drveca skupa & 40,6 & 43,0 & 11,6 & 1,8 & 100,0 \\
\hline
\end{tabular}

BROJ BILIAKA POOMLATKA PO HA (konada)

\begin{tabular}{|c|c|c|c|c|}
\hline Vrsta drveta & $\begin{array}{l}\text { Visine } \\
10-50 \mathrm{~cm}\end{array}$ & $\begin{array}{l}\text { Visine } \\
50-130 \mathrm{~cm}\end{array}$ & $\begin{array}{c}\text { Debljine } \\
0-5 \text { con na } 1,3 \mathrm{~m}\end{array}$ & Ukupno \\
\hline Jela & 1.839 & 214 & 500 & 2.553 \\
\hline Smrča & 964 & 357 & 36 & 1.357 \\
\hline Bukva & 107 & - & 36 & 143 \\
\hline Grab obični & 125 & - & 36 & 161 \\
\hline Ostali lišcari & 232 & 214 & - & 446 \\
\hline bkupno & 3.267 & 785 & 608 & 4.660 \\
\hline
\end{tabular}

unjer smese po broju biljaka podmlatka: jela 0,55 ; smrča 0,29; bukva 0,03; grab obični 0,03 ; ostali 1 išćcari 0,10 .

zastarceno je 19\%, a osteceno $29 \%$ od ukupnog brojabiljaka podnllatka.

Podmladak se javl jao jednolično rasporedjen u 57 slučajeva. U grupama $" 10 \%$ a istovremeno u oba navedena oblika u $33 \%$ slucajeva. 
Ponik (biljçice do $10 \mathrm{~cm}$ visine) javio se na 43: polozenih krugova u ovorn tipu šume.

\author{
OSNOVNI TIP: VI-b-4 \\ SUME JELE. I SMRCE NA LUVISOLU NA KRECNJAKU
}

a) 0 og $r$ a f skekarakteristike

Prosječna nadmorska visina: $1.100 \mathrm{~m}, \mathrm{~g}= \pm 5,5 \%, \mathrm{~s}= \pm 203 \mathrm{~m}$

Prosjecna inklinacija: $9^{\circ}, 9= \pm 23,9,5: \pm 7,1^{\circ}$

Ekspozicija: $S=15,1=7, J=10, z=11, k=3$ krugova.

b) $Z$ em i ji śte

Maticna podioga: Najrasprostranjenija maticna stijena je jedri i laporoviti krec̃njak, a u izuzetnim slucajevima javljaju se kristalasti dolomiti ili serija krečnjaka sa rożnjakom.

Svojstra zemljista: Ovaj tip zemljista se obrazuje $i$ održava samo na blazim reljefskim formama, manjeg nagiba, sa slabom do srednjom kament toscu. Zemljiste je dubokoga soluma, cesto skoro beskeletno do riedje skeletro, ovisno of karaktera stijene.

Organieni horizont ne prelazj debljinu od $4 \mathrm{~cm}$, ili izostaje.

lako nema vidljivih tragova erozije, humusno-akumulativni horizont je jako varijabilan, često plitak, a maksimalno dostiže debljinu od $25 \mathrm{~cm}$. Eluvijalni horizont takodjer ima razlicitu mocnost od 15 do 35 $\mathrm{cm}$. Po mehaničkom sastavu površinski dijelovi profila su ilovače, rjedje pjeskovite ilovače, a argiluvični Bt horizont glinovite ilovače $i$ ilovace. Struktura humusno-akumulativnog horizonta je zrnasta slabo izražena, a B horizonta poliedrična srednje izražena.

Ovo su duboka zemljišta i povoljnih vodno-fizičkih svojstava, ali nepovoljnih hemijskih osobina, što se djelomično može da kompenzira dubinom profita. 
Sastav drveca: uz jelu; smrču rijetko je zastupljena bukva, gorskj javor, bi.jeli bor, jarebika.

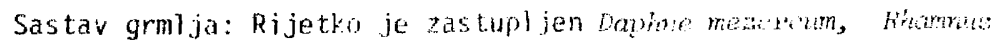

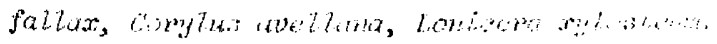

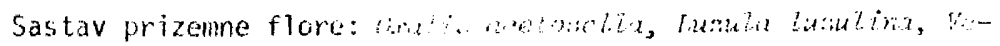

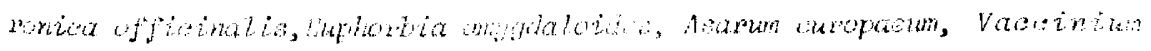

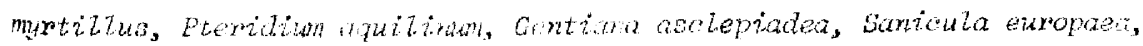
Galium rotuntifolizan. Mahovine su cesto vece pokrovnosti, potutwirian

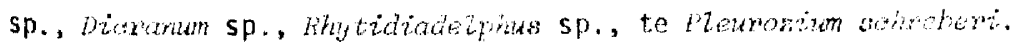

d) Produkcionekarakteristike

Voste erveca i onjer snjese: jola 0,57 ; sincza 0,39 ; bijeli bor 0,02; bukva 0,01; javor gorki i ostail liscari 0,01 .

Bonitetni razred stanisto : jela II,3; smrća lli,o.

Zastrtost th krošnjalt $\quad: 0,63: \mathrm{g}= \pm 12,2 \%, \mathrm{~s}= \pm 3.26$.

\begin{tabular}{|c|c|c|c|}
\hline Drvna zaliha & $\left(m^{3} / h a\right)$ & Godisnni zapreminski prirast & $\left(m^{3} / 1, a\right)$ \\
\hline jela & 223,6 & jela & 4,50 \\
\hline smróa & 154,2 & smröa & $3,7 ?$ \\
\hline bijeli bor & 5,9 & bijeli bor & i), $0 ?$ \\
\hline $\begin{array}{l}\text { bukva i ostali } \\
\text { liscari }\end{array}$ & 7,2 & bukva i ostali liscari & 0,07 \\
\hline Ukupno & 390,9 & Ukupno & 8,71 \\
\hline
\end{tabular}




\section{PROCENTUALNA DEBLJINSKA STRUKTURA ZALIHE}

\begin{tabular}{|c|c|c|c|c|c|c|c|}
\hline$\underset{(\mathrm{cm})}{\text { Debijinska klasa }}$ & $5-9,9$ & $\begin{array}{l}10= \\
19,9\end{array}$ & 20,9 & $\begin{array}{l}30- \\
49,9\end{array}$ & $\begin{array}{l}50- \\
79,9\end{array}$ & $\begin{array}{l}80 i \\
\text { vise }\end{array}$ & Ukupr \\
\hline Jela & 1,8 & 5,3 & 12,1 & 48,0 & 30,9 & 1,9 & 100,0 \\
\hline Smrža & 1,6 & 7,0 & 20,1 & 49,6 & 20,0 & 1,7 & 100,0 \\
\hline Bijeli bor & - & - & - & 100,0 & - & - & 100,0 \\
\hline Bukva s ost.liscarima & - & - & 9,1 & 36,3 & 52,6 & - & 100,0 \\
\hline Sve vrste drveća skupa & 1.6 & 5,9 & 15,0 & 49,2 & 26,6 & 1,7 & 100,0 \\
\hline
\end{tabular}

KVAL.ITETNA STRUKTURA ZALIHE ( $u$ \%)

\begin{tabular}{|c|c|c|c|c|c|}
\hline Tehnička kvalitetna klasa: & 1. & 2. & 3. & 4. & !kupno \\
\hline Jela & 52,8 & 34,7 & 10,5 & 2,0 & 100,0 \\
\hline 'mrča & 34,1 & 43,8 & 16,4 & 5,7 & 100,0 \\
\hline Bijeli bor & - & 100,0 & - & - & 100.0 \\
\hline Bukva s ostalim liscarima & - & 52,6 & 38,3 & 9,1 & 100,0 \\
\hline Sve vrste drveca skupa & 43,7 & 39,6 & 13,1 & 3,6 & 100,0 \\
\hline
\end{tabular}

BROJ BILJAKA PODMLATKA PO HA (komada)

\begin{tabular}{lrrrrr} 
& Vrsta drveta & $\begin{array}{c}\text { Visine } \\
10-50 \mathrm{~cm}\end{array}$ & $\begin{array}{c}\text { Visine } \\
50-130 \mathrm{~cm}\end{array}$ & $\begin{array}{c}\text { Debljine } \\
\text { Uncm na } 1,3 \mathrm{~m}\end{array}$ & Ukupno \\
\hline Jela & 1.587 & 609 & 870 & 3.066 \\
SmrCa & 413 & 783 & 348 & .544 \\
Bukva & - & 87 & - & 87 \\
Grab obicni & 696 & - & - & 696 \\
\hline Ukupno & 2.696 & 1.479 & 1.218 & 5.393 \\
\hline
\end{tabular}

Onjer smjese po broju biljaka podmlatka: jela 0,57; smrca 0,29; bukva 0,01; grab obični 0,13 .

Zastarčeno je $5 \%$, a oštećeno takodje $5 \%$ od ukupnog brojabiljaka podmlatka. 
Podmladak je bio jednolicno rasporedjen u $53 \%$ slučajeva. "1 arupama se javio u 16\%, a istovremeno u oba navedena oblika u 31 : slucajeva. Ponik (biljčice do $10 \mathrm{~cm}$ visine) javio se na 46 polozenih krugova.

\section{OSNOVNI TIP: VI-b-6}

SUME JELE I SMRCE NA DUBOKOM DISTRICNOM KAMBISOL.U

a) 0 rografskekarakteristike

Prosjecna nadmorska visina: $1.097 \mathrm{~m}, 9= \pm 4: 5= \pm 133 \mathrm{~m}$

Prosjecna inklinacija: $16^{\circ}, g= \pm 16, \mathrm{~s}= \pm 7.8^{\circ}$

Ekspozicija: $S=13, I=8, J=8, Z=10, R=0$ krugova

b) Zem I j i $\$ t e$

Maticna podloga: Preovladavaju verfenski sedimenti (pjesciri i glinci), pjescari, rožnjaci, silikatne brece, kvarcni pješcari, kloritošsti, dijabazi, kao i razlicite serije krečnjaka - rožnjaka, pjesciari laporci, pjescari - glinci, pjescari - glinci - roznjaci i dr.

Svojstva zemljišta: ovo su duboka zenljišta, vrlo cesto duhine fizioloski aktivnog profila preko $1 \mathrm{~m}$. Površinska kamenitost je matena. izuzev ako u seriji ima zlanova koji se teźe mehanički troše.pandamuze da ima i srednju kamenitost. Javlja se i erozija i to površinska slinog intenziteta najcešce na vecim nagibima. Sirovi humus iznosi dn ? im a humusno-akumulativni horizont do $10 \mathrm{~cm}$, ili je cak plici. Skeletnost. ir.vilo varijabilna $i$ krece se od beskeletnosti do vrlo velike skeletnosti, $\quad$ to najviše zavisi od matične podloge na kojoj se ovo zenljiste razvija. Po mehanickom sastavu su takodjer heterogena zeml jjsta od pjeskusa in ilimusa. Struktura im je slabo razvijena, a obicho je ovo svojstvo zavisno od teksture i sadrżaja humusa. I humusno-akumulativnom horizontu je najcesce zrnasta, slabo izražena, a u kambičnom prizmatična, poliedrična ilizrnasta, takodjer slabo izražena.

Ovo su zemijista nepovoljnih hemijskin svojstava. kbas se djelomicno kompenziraju velikom dubinom i uglavnom povoljnin vodno-fizičkin 
svojstava.

c) Vegetacijskekarakteristike

Sastav drveca: sa jelom i smrčom sporadicno su rastupljeni bu kva, bijeli bor, gorski javor, jasika.

Sactav grmlja: Medju malim brojem vrsta nešto cesce su zastup" ljene laphne moserim, Sambuss racemesa, Juniperus communis.

Sastav prizemne flore: Vacinum myrtillus, ocalis acetosella,

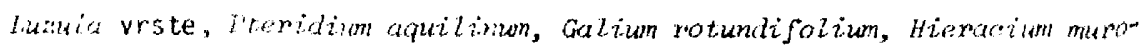

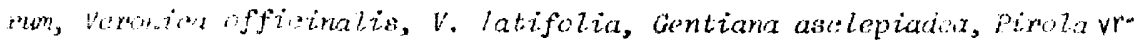
ste. Hean morcan. Sa vecon pokrovnasti prisutne su mahovine iz rado-

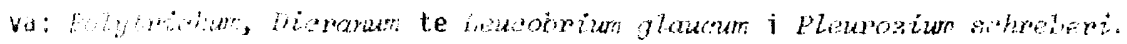

djprodukcionekarakteristike

Vrita drvecta $i$ omjer smjese: jela 0,53 ; smrča 0,$44 ; 05101 ; 1 ;-$ šari 0,03 .

Bonitetni razred stanista : jela $I I, 7$; snirca III,0.

lastrtost tla krošnjama $: 0,75 ; 9= \pm 7 \% ; s= \pm 0,17$.

Druna zaliha $\left(m^{3} / h a\right) \quad$ Godišnji zapreminskiprirast $\left(n^{3} / h d\right)$

\begin{tabular}{|c|c|c|c|}
\hline jela & 117,9 & jela & 4,18 \\
\hline smica & 96,9 & marca & $3,6^{9}$ \\
\hline ostali liscari & 6,1 & ostal liscari & 0,11 \\
\hline bk.upno & 220,9 & Hupno & 7,98 \\
\hline
\end{tabular}

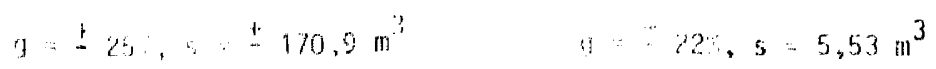


PROCENTUALNA OEBLJINSKA STRUKTURA ZALIHE

\begin{tabular}{|c|c|c|c|c|c|c|c|}
\hline $\begin{array}{l}\text { Debljinska klasa } \\
(\mathrm{cm})\end{array}$ & $5-9,9$ & $\begin{array}{l}10- \\
19,9\end{array}$ & $\begin{array}{l}20- \\
29,9\end{array}$ & $\begin{array}{l}30- \\
49,9\end{array}$ & $\begin{array}{l}50- \\
79,9\end{array}$ & $\begin{array}{l}80 \text { i } \\
\text { više }\end{array}$ & Ukupno \\
\hline Jela & 2,9 & 11,3 & 13,0 & 51,0 & 21,8 & - & 100,0 \\
\hline Smrča & 4,3 & 10,7 & 28,2 & 52,6 & 4,2 & - & 100,0 \\
\hline Ostali lišćari & - & - & - & 100,0 & - & - & 100,0 \\
\hline Sve vrste drveca skupa & 3,5 & 10,7 & 19,3 & 53,0 & 13,5 & - & 100.0 \\
\hline
\end{tabular}

KVALITETNA STRUKTURA ZALIHE $(u)$

\begin{tabular}{lrrrrrr}
\hline \multicolumn{1}{r}{ Tehnička kvalitetna klasa: } & 1 & 2 & 3. & 4. & Ukupno \\
\hline Jela & 40,2 & 47,2 & 11,7 & 0,9 & 100,0 \\
Smrča & 54,0 & 24,8 & 14,8 & 6,4 & 100,0 \\
Ostali lišćari & - & 55,3 & 44,7 & - & 100,0 \\
\hline Sve vrste drveća skıpa & 45,1 & 37,6 & 14,0 & 3,3 & 100,0 \\
\hline
\end{tabular}

BROJ BILJAKA PODMLATKA PO HA (komada)

\begin{tabular}{lcccc} 
& Vrsta drveta & Visine & Visine & Debljine \\
& $10-50 \mathrm{~cm}$ & $50-130 \mathrm{~cm}$ & $0-5 \mathrm{~cm}$ na $1,3 \mathrm{~m}$ & Ukupno \\
\hline Jela & 3.713 & 1.333 & 1.718 & 6.769 \\
Smrča & 2.487 & 179 & 641 & 3.307 \\
\hline Ukupno & 6.205 & 1.512 & 2.359 & 10.076 \\
\hline
\end{tabular}

Omjer smjese po broju biljaka podmlatka: jela 0,67 ; smrča 0,33.

Zastarčeno je $24 \%$ od ukupnog broja biljaka podmlatka.Podmladak nije oštećen.

Podmladak se javljao pojedinačno jednolično rasporedjen u $48 \%$ slučajeva, u grupama u 24\% slučajeva, a istovremeno, u oba navedena oblika u $28 \%$ stučajeva.

Ponik se javio na $41 \%$ položenih primjernih krugova. 
OSNOVNI TIP: VI-b-7

SUME JELE I SMRCE NA LUUISOLU NA SILIKATNTM STIJENAMA

a) orografskekarakteristike

Prosjecna nadmorska visina: $1.088 \mathrm{~m}, g= \pm 6: 5= \pm 156 \mathrm{~m}$

Prosjecna inklinacija: $11^{\circ}, g= \pm 25, s= \pm 6.4^{\circ}$

Ekspozicija: $S=8,1=6, J=5, Z=4, R=0$ krugova.

b) 2 e m 1 j i $\$$ t a

Maticna podloga: U obrazovanju ovin zemljista mogu da učestruju veliki broj stijena bilo kao pojedinačne ili u seriji. što je cesti slučaj. Majvažniji predstavnici bi bili: verfenski sedimenti, rožnjacipješcari, rožnjaci-krečnjaci, silifikovani krečnjaci,pješcari-glinci. filiti, pješčari-rožnjaci - glinci i dr.

Svojstra zemljista: Povrsina ovih zemljista može da bude beskamenita do srednje kamenitosti, bez erozije ili ako se javi u rjedjim slucajevima onda je slaba pouršinska.

Organični horizont je močnosti do oko $2 \mathrm{~cm}$, a humusno-akumulativni oko $10 \mathrm{~cm}$. Eluvijalni E horizont je debljine od $20-50 \mathrm{~cm}$. Ova zemIjizta ovisno od matične podloge mogu biti beskeletna do jako skeletna. Po mehanickom sastavu ovo su u povrsinskom dijelu profila ilovace ili pjeskovite ilovace (zavisno od maticne podloge), u argiluvičnom Bt su ilovace do glinovite ilovače, slabo izražene strukture.

Po hemijskim svojstvima ova zemljista su nepovoljna, ali zbog dubine fizioloski aktivnog profila i povoljnih vodno-fizickih svojstava ova njihova nepovoljna svojstva se djelomicno kompenziraju.

c) Vegetacijskekarakteristike

Sastav drveca: Uz jelu i smrcu rijetko su prisutni bukva, bijeli bor i gorski javor.

Sastav grmlja: Rijetke su vrste Daphrm mexeram, Juniperus eomminis, sambuche racemosa is, nigra. 
Sastavprizemne flore: Vacoiniwm myrtillus, Pteridiwn aquilimum, Oxalis acetosella, Luzula vrste, Hieracium murorum, Galium rotundifolium, Eestuca montana, Euphorbia amygdaloides, Veronica officinalis, $V$. latifolia, Aposeris foetida, carex sitvatica.

d) Produkcionekarakteristike

Vrste drveća i onjer smjese: jela 0,62 ; smrča 0,36 ; bijeli bor 0,01 ; breza 0,01 .

Bollitetni razred staništa : jela III,0; smrča $1 I I, 3$.

Zastrtost tla krošnjama : 0,$62 ; g= \pm 17 \%, s= \pm 0,25$.

\begin{tabular}{lrlr} 
Drvna zaliha & $\left(\mathrm{m}^{3} / \mathrm{ha}\right)$ & Godišnji zapreminski prirast $\left(\mathrm{m}^{3} / \mathrm{ha}\right)$ \\
jela & 221,6 & jela & 5,50 \\
senrća & 128,9 & smrča & 2,64 \\
bijeli bor & 2,1 & bijeli bor & - \\
breza & 3,5 & breza & 0,02 \\
\hline ukupno & 356,1 & ukupno & 8,16
\end{tabular}

$s=25 \%, s= \pm 204,1 \mathrm{~m}^{3} \quad g= \pm 32 \%, s= \pm 6,04 \mathrm{~m}^{3}$

PROCENTUALNA DEBLUINSKA STRUKTURA ZAL IHE

\begin{tabular}{lrrrrrrrr}
\multicolumn{1}{r}{$\begin{array}{l}\text { Debljinska klasa } \\
\text { (cm) }\end{array}$} & $5-9,9$ & $10-9$ & $20-$ & $30-$ & $50-$ & 80 i & Ukupno \\
& & 19,9 & 29,9 & 49,9 & 79,9 & više & \\
\hline Jela & 1,7 & 9,2 & 22,7 & 50,8 & 15,6 & - & 100,0 \\
Smrča & - & 2,3 & 16,1 & 59,4 & 22,2 & - & 100,0 \\
Bijeli bor & - & - & - & - & 100,0 & - & 100,0 \\
Breza & - & 53,1 & 46,9 & - & - & - & 100,0 \\
\hline Sve vrste drveca skupa & 1,0 & 7,1 & 20,4 & 53,1 & 18,4 & - & 100,0 \\
\hline
\end{tabular}




\begin{tabular}{lrrrrr}
\hline \multicolumn{1}{r}{ Tehnička kvalitetna klasa: } & 1 & 2 & 3. & 4. & Ukupno \\
\hline Jela & 34,9 & 39,3 & 24,2 & 1,6 & 100,0 \\
Smrča & 61,1 & 33,6 & 5,3 & - & 100,0 \\
Bijeli bor & - & 100,0 & - & - & 100,0 \\
Breza & - & - & - & 100,0 & 100,0 \\
\hline Sve vrste drveća skupa & 43,8 & 37,2 & 17,0 & 2,0 & 100,0 \\
\hline
\end{tabular}

BROJ BILJAKA PODMLATKA PO HA (komada)

\begin{tabular}{lrcccc}
\hline Vrsta drveta & $\begin{array}{c}\text { Visine } \\
10-50 \mathrm{~cm}\end{array}$ & $\begin{array}{c}\text { Visine } \\
50-130 \mathrm{~cm}\end{array}$ & $\begin{array}{c}\text { Debijine } \\
0-5 \mathrm{~cm} \text { na } 1,3,\end{array}$ & Ukupno \\
\hline Jela & 4.609 & 1.739 & 826 & 7.174 \\
Smrča & 870 & 174 & 174 & 1.218 \\
\hline Ukupno & 5.479 & 1.913 & 1.000 & 8.392 \\
\hline
\end{tabular}

Omjer smese po broju biljaka podmlatka: jela 0,85; smrča 0,15 . Zastarčeno je $8 \%$, a oštećeno isto toliko procenata od ukupnog broja bi7 jaka podmlatka.

Podmladak je bio pojedinačno jednolično rasporedjen u $67 \%$ slučajeva. U grupama se javio u 25\% slučajeva, a miješano u $8 \%$ slučajeva.

Ponik se javio na $70 \%$ položenih primjernih krugova.

$$
\text { OSNOVNI TIP: VI-b-8 }
$$

ŠUME JELE I SMRC̄E NA PSEUDOGLEJU

a) orografskekarakteristike

Prosječna nadmorska visina: $1.071, g= \pm 9 \%, s= \pm 139 \mathrm{~m}$

Prosječna inklinacija: $10^{\circ}, g= \pm 39 \%, s= \pm 6,0^{\circ}$

Ekspozicija: $S=5, I=3, J=2, Z=1, R=0$ krugova. 
Maticna podloga: Uglavnom preovladavaju serije izgradjemi ind pješcara glikaca, nježcara-ro:njaka, tufitnin pjescara, glinaca tilita i dr.

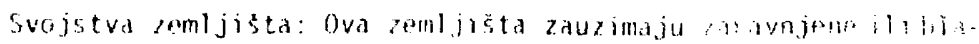

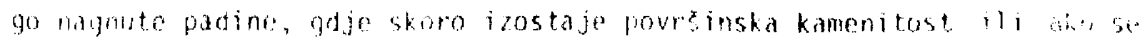

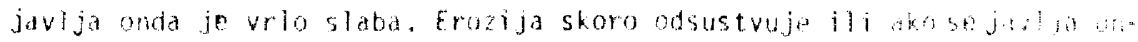
da je slaba povesinska. Skcletnost je slaba.

Organicni horizont u prosjeku iznosi 2 can, a humusna-akumulativni flože da bude $i$ do $20 \mathrm{~cm}$, goje je umbricnog tipa a najceste ie fille i ohrichog karaktera. Dubina ležanja nepropusnog sloja lli harbonta va

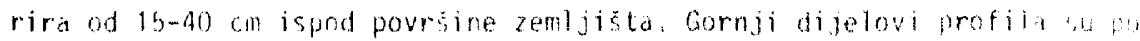
mehanickum sastavu ilovaca il pjeskovite llovace, a dublji nopropusni horizonti i slojevi ilovace ili glinovite ilovace, slabo izrajera stmkture priznatione ili arulusis.

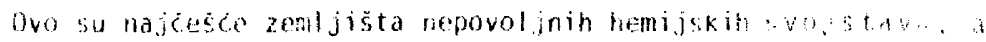

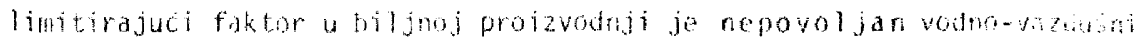
reżin. i dubina nepropasnog claji.

c) $\operatorname{veg} g$ tacijskekarikteristika

Sastav drveca: Osim jele i smrce rijetko se pojavljuje bijeli bor i jarebika.

Sastav grmlja: Vrlo rijetke pojave laphne merom, sambuad racemosa is. nigra.

Sastav prizemne flore: Festuca montana, Lusula vrste, oxalis acetosella, Vaceinium myrtillus, Lyeimachia nummularia, Agrostia canina, suncus sp., Hiemaciam murorum i dr.

d) Produkcione karakteristike

Vrsta drveca $i$ omjer smjese: jela 0,49 ; smrza 0,49 ; joha 0,02 . Bonitetni razred staništa: jela III,3; 5 mrça III,4.

Zastrtost tla krosnjama: 0,$58 ; g= \pm 29 \%, s= \pm 0,26$. 


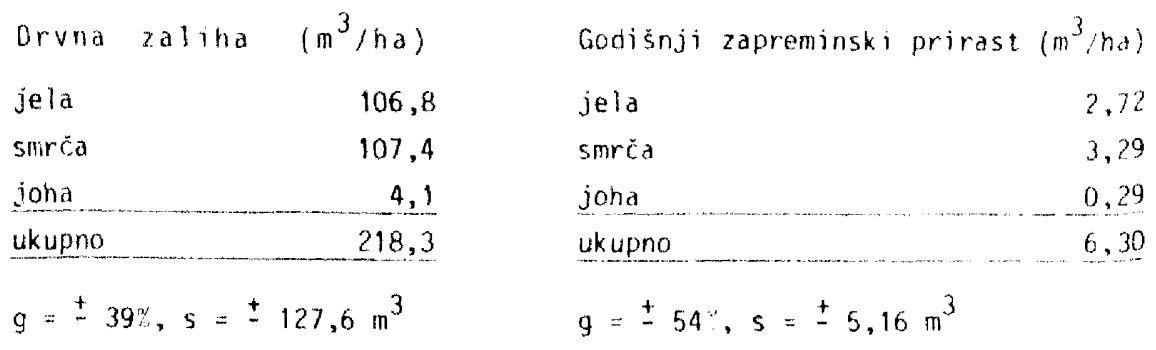

PROCENTUAL NA DEBLJINSKA STRUKTURA ZAL IHE

\begin{tabular}{|c|c|c|c|c|c|c|c|}
\hline $\begin{array}{l}\text { Debljinska klasa } \\
(\mathrm{cm})\end{array}$ & $5-9,9$ & $\begin{array}{l}10- \\
19,9\end{array}$ & $\begin{array}{l}20 \\
29,9\end{array}$ & $\begin{array}{l}30- \\
49,9\end{array}$ & $\begin{array}{l}50- \\
79,9\end{array}$ & $\begin{array}{l}80 \text { i } \\
\text { više }\end{array}$ & Ukupno \\
\hline Jela & 3,5 & 6,5 & 16,8 & 56,6 & 16,6 & - & 100,0 \\
\hline Smrza & 1,9 & 31,4 & 39,7 & 13,6 & 13,4 & - & 100,0 \\
\hline Joha & - & 100,0 & $\ldots$ & - & - & $\sim$ & 100,0 \\
\hline Sve vrste drveca skupa & 2,6 & 20,4 & 27,7 & 34,5 & 14,8 & - & 100,0 \\
\hline
\end{tabular}

KVALITETNA STRUKTURA ZAL IHE ( $u \%)$

\begin{tabular}{lrrrrr} 
Tehnička kvali tetna klasa: & 1 & 2 & 3 & 4 & Ukupno \\
\hline Jela & 40,1 & 31,3 & 28,6 & - & 100,0 \\
Smrča & 63,6 & 20,9 & 15,5 & - & 100,0 \\
Joha & - & - & - & 100,0 & 100,0 \\
Sve vrste drveca skupa & 50,9 & 25,6 & 21,6 & 1,9 & 100,0 \\
\hline
\end{tabular}

BROJ BILJAKA PODMLATKA PO HA (komada)

\begin{tabular}{lccccc} 
& Vrsta drveta & $\begin{array}{c}\text { Visine } \\
10-50 \mathrm{~cm}\end{array}$ & $\begin{array}{c}\text { Visine } \\
50-130 \mathrm{~cm}\end{array}$ & $\begin{array}{c}\text { Debljine } \\
0-5 \mathrm{~cm} \text { na } 1,3 \mathrm{~m}\end{array}$ & Ukupno \\
\hline Jela & 3.545 & 727 & 364 & 4.636 \\
Smrča & 2.364 & 1.455 & 545 & 4.364 \\
\hline Ukupno & 5.909 & 2.182 & 909 & 9.000 \\
\hline
\end{tabular}

Omjer smjese po broju biljaka podmlatka: jela 0,$52 ;$ smrca 0,48 .

68 
Podmiadak nije zastarcen. Osteceno je $14 \%$ od ukupnog broja biljaka podmlatka.

Podmladak se javio jednolicno pojedinacno rasporedjen u 14 : sluc̆ajeva. U grupama u $57 \%$ slućajeva, a mi jesano u $29 \%$ slućajeva.

Ponik se javio na $91 \%$ polozienih krugeiva.

\section{Sume since}

OSNIVRI TIP: VI-C-1

a) 0 rografskekarikteristike

Prosjecna nadmorska visina: $1.218 \mathrm{~m}, \mathrm{~g}= \pm 9, \mathrm{~s}= \pm 19 \mathrm{~m}$ Prosječna inklinacija: $19^{\circ}, g= \pm 34,5= \pm 12, ?^{\circ}$

Ekspozicija: $S:=1,1=2, J=3, Z=10, R=0$ krugova.

b) 2 em 1 jis

Matiena podioga: Jedri, cisti krečnjaci.

Svojstva zemljišta: Povrşina je visokog stepena kamenitosti, i skoro hez vidljivo izražene erozije, iako je inklinacija velika.

Ovo su plitka zemljišta i vrlo skeletna, ilovasta do glinovita po mehaničkom sastavu. Imaju srednje izraženu zrnastu strukturu. Pojaya sirovog humusa je evidentna do debljine od $3 \mathrm{~cm}$.

Produktivnost ovih zemljišta je ograničena plitkocom zemljišnog soluma i skeletnošcu, tako da su ova staništa jako kserotermna.

c) Vegetacijskekarakteristike

Sastav drveca: Uz smrču vrlo rijetko su zastupljene, većinom $u$ podstojnim etażama, jela, jarebika, gorski javor, bukva.

Sastav grmlja: Rhamrus fallax, lomicera nigra, L, xylostewn, I. alpigena, Daphne mezerezun. 
Sastav prizemne flore: Asamem europaezon, Oxalis ace tosella, pirola vrste, Melampymon silvaticum, Euphorbia amygdaloides, Arcmonia agrimonioides, Gentiana asclepiadea, Lamium iuteum, Cardarine vrste. Od mahovina najbrojnije su iz roda Phiftidiatelphas.

d) Produkcionekarakteristike

Vrste drveća i omjer smjese: smría 0,95; bukva 5 gorskim javorom 0.05 .

Bonitetni razred staništa : smräa 111,6 ,

Zastirtost tla krośnjama $: 0,59 ; 9= \pm 23: s= \pm 0,25$.

Urvna zaliha (m ${ }^{3}$ ha) Godišnji zapremiriski prirast. $\left(m^{3} / h a\right)$

$\begin{array}{llll}\text { Smréa } & 216,3 & \text { smrča } & 4,89\end{array}$

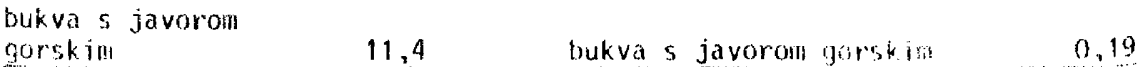

ukupno $\quad 227,7 \quad$ ukupno $\quad \downarrow, 08$

$g= \pm 40 \%, \mathrm{~s}= \pm 172,0 \mathrm{~m}^{3} \quad \mathrm{~g}= \pm 40 \%, \mathrm{~s}= \pm 40 \%, \mathrm{~s}= \pm 3,82 \mathrm{~m}^{3}$

PROCENTUALNA DEBLJINSKA STRUKTURA ZNLIHE

\begin{tabular}{|c|c|c|c|c|c|c|c|}
\hline $\begin{array}{c}\text { Debljinskn } k l \\
(\mathrm{Cm})\end{array}$ & 90 & $\begin{array}{l}10- \\
19,9\end{array}$ & $\begin{array}{l}20- \\
29,9\end{array}$ & $\begin{array}{l}30 \\
49,9\end{array}$ & $\begin{array}{l}50- \\
79,9\end{array}$ & $\begin{array}{l}80 i \\
\text { više }\end{array}$ & \\
\hline Smrča & &, 5 & & & & 1,4 & 100,0 \\
\hline 3ukvas javarom gorskim & - & 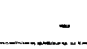 & - & 100,0 & - & 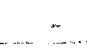 & 100,0 \\
\hline ive vrste drveca skupa & +9 & 1,9 & 12,1 & 58,6 & 13,2 & 1,3 & 100,0 \\
\hline
\end{tabular}

KVAL ITETNA STRUKTURA ZAL IHE (U\%)

Tehnicka kvali tetna klasa:
Snrča


BROJ BIL JAKA PODMLATKA PO HA (kOMAda)

\begin{tabular}{|c|c|c|c|c|c|}
\hline & Vrsta drveta & $\begin{array}{l}\text { Visine } \\
10-50 \mathrm{~cm}\end{array}$ & $\begin{array}{c}\text { Visine } \\
50-130 \mathrm{~cm}\end{array}$ & $\begin{array}{l}\text { Debljine } \\
0-5 \mathrm{~cm} \text { na } 9.3 \mathrm{~m}\end{array}$ & Ukupno \\
\hline Jela & & 4.38 & 250 & 125 & 813 \\
\hline Smréd & & 438 & $\therefore$ & $56 ?$ & 1.000 \\
\hline Ulk.upno & & 876 & 250 & 687 & 1.813 \\
\hline
\end{tabular}

Omjer smjese po broju biljaka podmlatka: jela 0.45 : smrča 0.55 Podmladak nije ostecen ni zastarcen.

U /5. slucajeva podmadak se javio jedrolicno pojedinacino rasporedjen, a u grupama u $25 \%$ sluçajeva.

Ponik se javio na $25 \%$ primjernih povrsina.

$$
\text { OSNOVNI TIP: VI-C-3 }
$$

SUME SMRCE NA PLI ITKOM KALKOKAMBISOLU

a) 0 rografskek a rakteris t jke

Prosječna nadmorska visina: $1.121 \mathrm{~m}, \mathrm{~g}= \pm 11 \%, \mathrm{~s}= \pm 206 \mathrm{~m}$ Prosjecha inklinacija: $13^{\circ}, g= \pm 47 \%, s= \pm 9,9^{\circ}$

Ekspozicija: $S=6, I=1, J=4, Z=2, R=0$ krugova,

b) $Z$ e m 1 j i 5 t a

Matična podloga: Razne vrste krečnjaka (jedri, laporoviti, žIjezoviti, konglomeratični. dolomitični, te serije krečnjaka sa rožnja(ima).

Svojstva zemljišta: Površinska kamenitost ovih plitkih zemljista je srednja do visoka sa velikom skeletnoscu profila. Erozija je slabo izražera, ali ind pojava slabe površinske.

Organicni horizont nože da bude do $5 \mathrm{~cm}$, ali može $i$ da odsustvuje. Humusno ik.umulativni horizont je promjenljive dubine, al i ne prelazi preko ls com. Po mehanickom sastavu ovo su jlovaste glinuse do glinuse, sreinje israiene strukture u povrinskom horizontu ernaste, a u kambičnom 
poliedricne vrlo stabilne. Ova zemljista su siromašna na fizioluski aktivnum fosforu, a srednje sa kalijumom. Zbog plitkoce profila, te skeletrosti, ovo su suha stanista.

c) Vegetacijskekarakteristika

Sastav drveca: smrëa, a u podstojim etażama su rijetko rastuplipie jela, jarebika, gorski javor, bukwa.

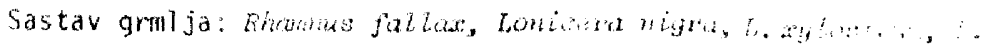

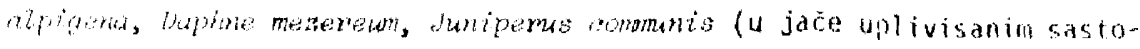
jitima).

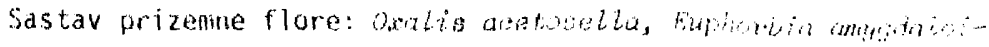

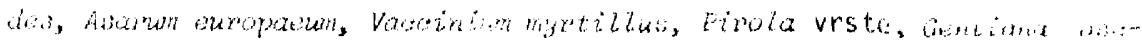

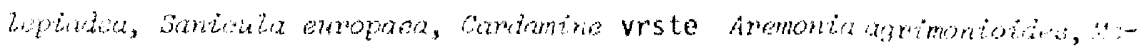

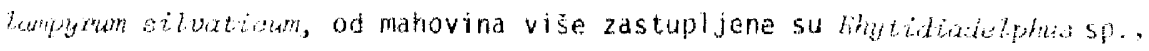

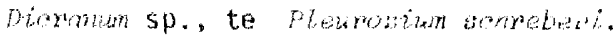

d) Produkcione karakteristika

Vrsta drveca i omjer smjese: smrća 1,0.

Bonitetni razred stanista: smrëa $1 \mathrm{~V}, 2$.

Zastrtost tla krošnjama: 0,$52 ; 9= \pm 27 \% ;= \pm 0,23$.
Drvia zaliha $\left(m^{3} / h a\right)$
Godišnji zapreminski prirast $\left(m^{3} / h a\right)$
smróa
166,0
smrča
$4,0.1$
$q= \pm 67 \%, s= \pm 184,9 \mathrm{~m}^{3}$
$g= \pm 53 \%, s= \pm 3,56 \mathrm{~m}^{3}$

PROCENTUALNA DEBL.JINSKA STRUKTURA ZALIHE.

\begin{tabular}{cccccccccc}
$\begin{array}{c}\text { Debljinska klasa } \\
(\mathrm{cm})\end{array}$ & $5-9,9$ & $\begin{array}{l}10 \\
19,9\end{array}$ & $\begin{array}{l}20 \\
29,9\end{array}$ & $\begin{array}{l}30 \\
49,9\end{array}$ & $\begin{array}{l}50,9 \\
\text { vise }\end{array}$ & Ukupno \\
\hline Silca & 3,5 & 20,8 & 18,1 & 53,7 & 3,9 & - & 100,0 \\
\hline
\end{tabular}

$7 i$ 
KVALITETNA STRUKTURA ZALIHE $(U \%)$

\begin{tabular}{lcccccc}
\hline Tehnička kvalitetna kiasa: & 1. & 2. & 3. & 4. & Ukupno \\
\hline Smrča & 15,6 & 41,7 & 40,3 & 2,4 & 100,0 \\
\hline
\end{tabular}

BROJ BILJAKA PODMLATKA PO HA (komada)

\begin{tabular}{lrrrr}
\hline \multirow{2}{*}{ Vrsta drveta } & $\begin{array}{c}\text { Visine } \\
10-50 \mathrm{~cm}\end{array}$ & $\begin{array}{c}\text { Visine } \\
50-130 \mathrm{~cm}\end{array}$ & $\begin{array}{c}\text { Debljine } \\
0-5 \mathrm{~cm} \mathrm{na} 1,3 \mathrm{~m}\end{array}$ & Ukupno \\
\cline { 2 - 5 } Jela & - & 303 & - & 308 \\
Smrča & 1.000 & 308 & 154 & 1.462 \\
Bukva & - & - & 692 & 692 \\
Ostali lišćari & 538 & - & - & 538 \\
\hline Ukupno & 1.538 & 616 & 846 & 3.000 \\
\hline
\end{tabular}

Omjer smjese po broju biljaka podmlatka: jela 0,10, smrča 0,49; bukva 0,49 ; ostali lišćari 0,18 .

Podmladak nije zastarčen ni oštećen.

U $80 \%$ slučajeva podmladak je bio jednolično pojedinačno rasporedjen po površini, a u $20 \%$ slučajeva javljao se u grupama.

Ponik se javio na $31 \%$ položenih krugova.

\section{OSNOVNI TIP: VI-C-4}

ŠUME SMRC̄E NA DUBOKOM KALKOKAMBISOLU

a) 0 rografske karakteristike

Prosječna nadmorska visina: $1.200 \mathrm{~m}, \mathrm{~g}= \pm 6 \%, \mathrm{~s}= \pm 194 \mathrm{~m}$

Prosječna inklinacija: $13^{\circ}, g= \pm 26 \%, s= \pm 8,4^{\circ}$

Ekspozicija: $S=6, I=5, J=5, Z=11, R=0$ krugova. 


\section{b) $z e m / j$ is $t$ a}

Maticna podloga: Uglavnom čisti jedri krecnjaci, a rjedje la horoviti, dolomitizirani, konglomeraticni krecnjaci lili serije krecniaka sa drugin silikatnin stijenama (roznjaci).

Svojstva zemljista: Zemajiste je duboko sa jako ispol from onvrsinskom kammitoscu, te se rijetko susrece poursina bez kamenja, a to je samo slucaj ako se radi a laporovitom krecnjaku. Pojava erozlo ic do tako cesta, a kina se javija onda je površinska slabog intenziteta

Organichi horizont ne prelazi debljinu od 4 com, a hamusio aki: nulativni tok, ako nije erodiran u prosjeku iznosi 10 cm. Kambicni horizont je srednje skeletan. Struktura humasnowakumulativnog horizont. ie

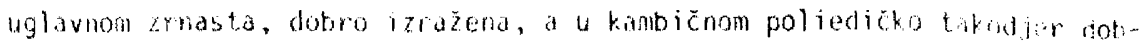
ro izrazena. Fo mehanickall sastavu su ilovace do glinovite llovace ki. sele reakcije i srednje zasicene sa bazama, slabo obezbijedierie bi lju pristupacim fosforom, a srednje kal jumom. Zbog stabilme sruktire i la.

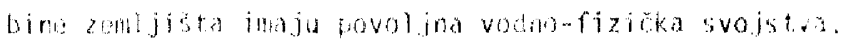

a) Vegetacijskekarakteristis

Sastav arveca: Smrca uz rijetku primjesu jele, gorskoj javora, bukve u podstojim atazan:

Sastav grmlja: ionicera nigra, L. xylosteum, l. alpitura, l.: :mous fallax, baphne mesereum, duriperus communis (u jače uplivisanim sastojinama).

Sastav prizemne flore: Festuad silvatioa, pteridium aquilima (u jaće uplivisanim sastojinama), luaula vrste, Euphorbia amygdaloides, Agamam europazm, Sanioula europaea, Vaceiniam myrtillua, onalis aretoneLha, Gertiana asclepiadea, Galium rotundifolium, Hirola vrste, Hierar iun murom, Melasipym silvatioum, Athyrium filix femina, Nophodium fil: was, Polygonatum vertioillatum, cardomine vrste i druge. Cesto su vece

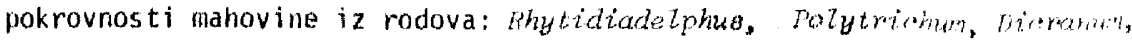
te Pleuroaium achreleri. 
d) Produkcione karakteristike

Vrsta drveca i omjer smjese: jela s bukvom 0,01; smrca $0,99$.

Bonitetnj razred stanista: smrca III, 1 .

Zastrtost tla krosnjama: 0,$53 ; \mathrm{g}= \pm 18 \%, \mathrm{~s}= \pm 0,24$.

Drvna zaliha ( $m^{3} /$ ha) ondisnji zapreminsti prirast (n ${ }^{3} /$ hit

\begin{tabular}{|c|c|c|c|}
\hline jela s bukvom & 2.4 & jel at s bukvom & 0.09 \\
\hline snnrca & 182,5 & smróa & $6,5 !$ \\
\hline ukupro & 184,9 & ukupno & 6.60 \\
\hline
\end{tabular}

$9= \pm 27 \%, \mathrm{~s}= \pm 126,1 \mathrm{~m}^{3} \quad 9= \pm 36 \%, \mathrm{~s}= \pm 5.96 \mathrm{~m}^{3}$

PROCFNTUAL NA DEBLIINSKA STRUKTURA ZALIIE

\begin{tabular}{|c|c|c|c|c|c|c|c|}
\hline $\begin{array}{l}\text { Debljinska klasa } \\
\text { (cm) }\end{array}$ & $5-9,9$ & $\begin{array}{l}10 \\
19,9\end{array}$ & $\begin{array}{l}20 \\
29,9\end{array}$ & $\begin{array}{l}30- \\
49,9\end{array}$ & $\begin{array}{l}50 \div \\
79.9\end{array}$ & $\begin{array}{l}80 \text { i } \\
V 150\end{array}$ & likumo \\
\hline Jela s bukvom & $\cdots$ & 12,1 & 87.9 & - & - & - & 100,0 \\
\hline Simrca & 4,5 & 15,1 & 26,5 & 47,1 & 6,8 & - & 100.0 \\
\hline Sve vrste drveca skupa & 4,4 & 15,0 & 27.4 & 46,4 & 6,8 & - & 100,0 \\
\hline
\end{tabular}

KVALITETNA STRUKTURA ZALIHE. (U )

\begin{tabular}{|c|c|c|c|c|c|}
\hline Tehnicka kvali tetna klasa: & 1 & 2 & 3. & 4. & Ukubno \\
\hline Jela s bukvom & - & - & - & 100,0 & 100,0 \\
\hline Surca & 54,5 & 18,9 & 25,0 & 1,6 & 100,9 \\
\hline Sve viste drveca skupa & 53,8 & 18,7 & 24,6 & 2,9 & 100.9 \\
\hline
\end{tabular}

BROJ BILJAKA PODMLATKA PO HA (komada)

\begin{tabular}{lrrrrr} 
& Vrsta drveta & $\begin{array}{c}\text { Visine } \\
10-50 \mathrm{~cm}\end{array}$ & $\begin{array}{c}\text { Visine } \\
50-130 \mathrm{~cm}\end{array}$ & $\begin{array}{c}\text { Debijine } \\
0-5 \mathrm{~cm} \text { na } t, 3 \mathrm{~m}\end{array}$ & Ukuprio \\
\hline $\mathrm{Jela}$ & 222 & - & - & 222 \\
Simrća & 3.148 & 1.333 & 4.44 & 4.925 \\
\hline Ukupno & 3.370 & 1.333 & 444 & 5.147 \\
\hline
\end{tabular}


Omjer smjese po broju biljaka podmlatka: jela 0,04 , smrča 0,96 . Zastarčeno je $20 \%$, a isto toliko biljaka podmlatka je ośtećeno.

Podmladak se u $90 \%$ slučajeva javljao pojedinačno jednolično rasporedjen. U preostalih 10\% slučajeva javljao se kombinovano u grupama $i$ pojedinačno.

Ponik se javio na $44 \%$ primjernih krugova.

OSNOVNI TIP: VI-C-5

SUME SMRCE NA LUVISOLU NA KRECNJAKU

a) $0 r o g r a f s k$ e $k$ a $r$ akteristike

Prosječna nadmorska visina: $1.274 \mathrm{~m}, \mathrm{~g}= \pm 10 \%, \mathrm{~s}= \pm 264 \mathrm{~m}$

Prosječna inklinacija: $6^{\circ}, y= \pm 43 \%, s= \pm 4,80$

Ekspozicija: $S=4, J=5, J=4, Z=3, R=2$ kruga.

b) $z e m i j i s t a$

Maticni supstrat: uglavnom lereznjaci (laporoviti,konglonerati* cni i drugi).

Svojstra zentjišta: Ovo su dubeika zemljišta wale površinske kamenitosti. Odrz̈avaju se uglavrom na potezima reljefa male inklinacije ili 4 drepresi jama. Organicri horizont je plitak, a humusno akumulativni do 10 ch (rjedje i dublje), a eluvijalni u prosjeku $25^{5}$ cll. Skeletnost :rofila jo malena sa pojedinacriom komadima ili sasvill izostaje. Pomehani tom sastavu poursinski dijelovi su ilovasti, a argiluvicni Bt horizont rajčesce medstavija ilovastu glinušu ili glinusu.

Struktura humusno akumulativnog horizorita je zrnasta, dubo izrazena a dublje E horizolit ima slabije izraženu poliedričnu strukturu. bit harizont. ima vrlo dohro izraženu poliedricinu strukturu.

Ovo su kisela zembista, slabo obezijedjena sa fosforma sredrije do slabo sa kalijumbm. Zoog velike dubine fizioloski aktivrog profilo ava zemijista imaju povoline vodnowiztcke bohtine. 


\section{c) Vegetacijskekarakteristik?}

Sastav drveca: Osim smrce, rijetko su u podstojnim etaźalla $2 a-$ stupijene jela, gorski javor, bukva.

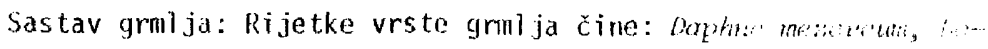

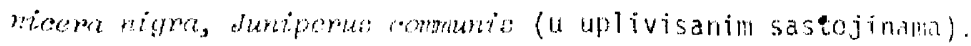

Sastav prizerne flore: Aposerata foetidi, linsula veste, wa

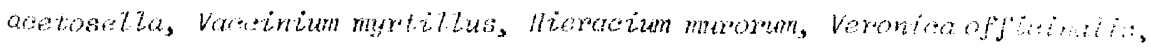

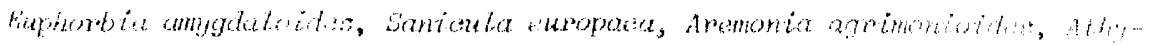

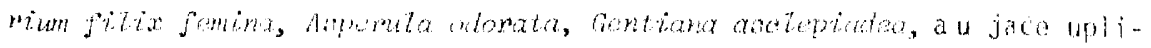

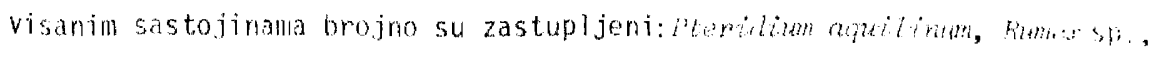

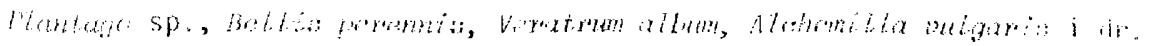

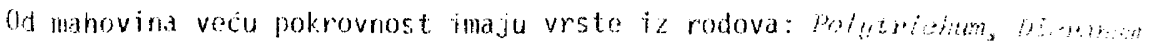

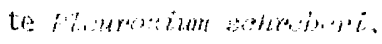

d) Produkcionekarakteristike

Vrsta drveta $i$ omjer smjest: smrca 1,0

Bonitetni razred stanista: smrca 11,9

Zastrtost tla krosnjama: 0,$44 ; 0 \cdots \pm 35 \% ; s= \pm 0,31$.

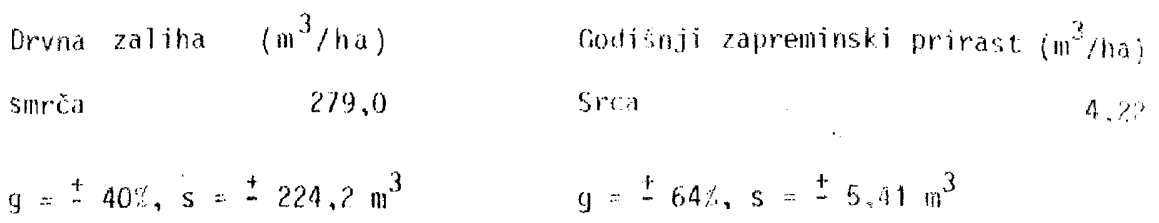

PROCENTUALNA DEBLJINSKA STRIJKTIJRA ZAL IIIE

\begin{tabular}{ccccccccc}
$\begin{array}{c}\text { Debljinska klasa } \\
\text { (cmlil }\end{array}$ & $5-9,9$ & $10-$ & $20-$ & 30 & $50-$ & 80 i \\
Snica & 0,9 & 9,4 & 14,3 & 26,5 & 46,2 & 6,7 & 100,0 \\
\hline
\end{tabular}

KVALITETNA STRIKTURA ZALIHE $(u \%)$

Tehnicka kvali te tna klasa: 1. 2. 3. 4. 4kupno Smrea $\begin{array}{llllll}26,0 & 53,3 & 17,1 & 3,6 & 100,0\end{array}$ 
BROJ BILJAKA PODMLATKA PO HA $(u z)$

\begin{tabular}{ccccc} 
Vrsta drveta & $\begin{array}{c}\text { Visine } \\
10-50 \mathrm{~cm}\end{array}$ & $\begin{array}{c}\text { Visine } \\
50-130 \mathrm{~cm}\end{array}$ & $\begin{array}{c}\text { Debljine } \\
0-5 \mathrm{~cm} n a 1,3 \mathrm{~m}\end{array}$ & Ukupno \\
\hline Smrča & 2.556 & 2.000 & 833 & 5.389 \\
\hline
\end{tabular}

Osim smrče u podmlatku nisu zapažene druge vrste drveça.

Podmladak nije zastarčen ni oštečen. Najčešce se javljao pojedinačno, 43\% slučajeva. U grupana se javio u $29 \%$ slučajeva, a u oba navedena oblika u 28\% slučajeva.

Ponik se javio na $44 \%$ primjernin krugova.

OSHOVNI TIP: VI-C-7

SUME SMRCE NA DUBOKOH DISTRICNON KAMBISOLU

a) orografske karakteristiks:

Prosjec̈na nadmorska visina: $1.065 \mathrm{~m}, \mathrm{~g}= \pm 8 \%, \mathrm{~s}= \pm 234 \mathrm{~m}$

Prosječna inklinacija: $15^{\circ}, g= \pm 21 \%, s= \pm 8,5^{\circ}$

Ekspozicija: $S=10, I=9, J=3, Z=8, R=1 \mathrm{krug}$.

b) 7 e m l j i $\xi \mathrm{ta}$

Matična podloga: Vrlo je različita $i$ tako se nogu susrestiverfenski pješçari i glinci, kvarcni pješcari, ražnjaci, glinci, pješcari, kvarc porfiri, bilo kao homogene stijene ili u kombinaciji sa istim ili drugim stijenama kao što su krečnjaci, laporci čineci serije.

Svojstva zemfjišta: Zemljišta su na ovim supstratima vrlo različite dubine fiziološki aktiunog profila, ali su ipak uvijek duboka do vrlo duboka, kada se radi o rastresitijim supstratima. Zbog toga su skoro wijek na poursini bez kamenitosti, izuzev ako se jave turdje stijene (kvarc porfir) ili u seriji ako se javlja krečnjak onda on cini površin sku kamenitost. Pojava erozije pod ovim sumama je rijetka izuzev ako su veci nagibi, tada može da dostigne i srednji intenritet. Uglavnom je po- 
vršinske prirode.

Organični horizont je različite debljine $i$ ne prelazj $5 \mathrm{~cm}$, a može da izostaje. Hunusno-akumulativni horizont takodje je vrlo varijabilan, a ako je dobro očuvan ne prelazi $15 \mathrm{~cm}$. (Na nekim lokalitetina j. i močniji). Ohričnog je varijeteta. Zbog heterogenosti matične podloge znatno varira skeletnost $i$ mehanički sastav. Srednje su do jako skeletne (rjedje slabo ili beskeletne ilovače do glinovite ilovače, a rjedje pjeskuše ili glinuše).

Struktura je slabo izražena zrnasta. Po reakciji sukisela,slabo obezbijedjena hranjivima, a zbog dubine fizioloski aktivnog profila u pravilu su povoljnih vodno vazdušnih svojstava.

c) Vegetacijskekarakteristike

Sastav drveća: U monodominaritnim sumama smrče rijetko suprisuthe druge vrste $i$ to pretežno u podstojnim etažana: jela, gorski javor. jarebika, bukva.

Sastav grmlja. Medju rijatkirn vrstama grmija karakteristične su Lonicera rigra, baphne mesereum te fumpora commenis (u jače uplivisanim sastojinama).

Sastav prizenne flore: Deschompsia flemosa, aralis aretoesta,

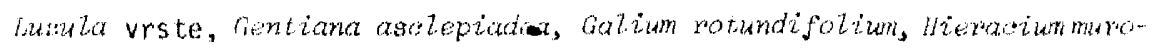
wam, Veronica officinatis, V. Latifolia, Molompymatabatiam, pirola vrste, potentilla execta, Sireglingia dexumbens, Lyropodium clanatum, $L$. annotimum. Veća pokrovnost mahovina je posebno obilježje ovih šuma: polytrichum sp., Leucobrium glaucum, Dicranum sp., sphagnum sp., plaurosinm sohreberi.

d) Produkcionekarakteristike

Vrsta drveta j omjer smjese: smrča 0,97 ; bukva s ostalim li carima

Bonitetni razred staništa : smrča $I I, 9$

lastrtost tla krošnjama : 0,$54 ; g= \pm 18 \% ; s= \pm 0,27$. 


\begin{tabular}{|c|c|c|}
\hline Orvna zalina & $\left(m^{3} / h a\right)$ & Godisnji zapreminski prir \\
\hline $\operatorname{smr} \check{c} a$ & 230,1 & smirta \\
\hline $\begin{array}{l}\text { bukva s ostalim } \\
\text { liscarima }\end{array}$ & 6,8 & bukva s ostalim liscarima \\
\hline ukupno & 236.9 & ukupno \\
\hline
\end{tabular}

PROCENTUAL DA DEBLUINSKA STRUKTURA ZALIIE

\begin{tabular}{|c|c|c|c|c|c|c|c|}
\hline $\begin{array}{c}\text { Debrjinska klasa } \\
(\mathrm{cm})\end{array}$ & $5-9,9$ & $\begin{array}{l}10- \\
19,9\end{array}$ & $\begin{array}{l}20- \\
29,9\end{array}$ & $\begin{array}{l}30 \\
49,9\end{array}$ & $\begin{array}{l}50- \\
79,9\end{array}$ & $\begin{array}{r}90 i \\
v i s e\end{array}$ & likunno \\
\hline Smici & $4,:$ & 7,6 & 29.1 & 36,0 & 22,8 & 0,7 & 100,19 \\
\hline Bukva s ost. 1 iscarima & 17,1 & 18,5 & - & 64.4 & - & $\therefore$ & 100,0 \\
\hline Sve urste drveca skupa & 5,2 & 7,9 & 27,3 & 36,8 & 22,2 & 0,1 & 100.0 \\
\hline
\end{tabular}

KVALITETNA STRUKTURA ZAL IHE ( $(u, r)$

$\begin{array}{lrrrrr}\text { Tehnicka kvalitetna klasa: } & 1, & 2 & 3 & 4 & \text { ukupro } \\ \text { Smrca } & 74,1 & 22,1 & 2,7 & 1,1 & 100,0 \\ \text { Bukvas ostalim liscarima } & 2,4 & - & 64,4 & 33,2 & 100,0 \\ \text { Sve vrste drveca skupa } & 72,0 & 21,4 & 4,5 & 2,1 & 100.0\end{array}$

BROJ BIL JAKA PODMLATKA PO HA (Komada)

\begin{tabular}{|c|c|c|c|c|}
\hline Vrsta drveta & $\begin{array}{l}\text { Visine } \\
10-50 \mathrm{~cm}\end{array}$ & $\begin{array}{c}\text { Visine } \\
50.130 \mathrm{~cm}\end{array}$ & $\begin{array}{c}\text { Debl jire } \\
0-5 \mathrm{~cm} \text { na } 1.3 \mathrm{~m}\end{array}$ & Ukupno \\
\hline dela & 839 & 761 & 143 & 1.743 \\
\hline Snurca & 1.645 & 901 & 2.060 & 4.606 \\
\hline Hrast kitnjak & 1.065 & 129 & - & 1.19 .1 \\
\hline Grab obicui & - & - & 194 & 194 \\
\hline IKutno & 3.549 & 1.791 & 2,397 & 7.737 \\
\hline
\end{tabular}

Omjer smjese po broju biljaka podmlatka: jela 0,$22 ;$ smrča 0.60 ; hrast kitniak 0,15; grab obieni 0,03 
Zastarčeno je $32 \%$, a ostećeno $42 \%$ od ukupnog brojabiliaka pocimatka.

Podmladak je bio jednolično rasporedjen u $21 \%$ slučajeva. Ugrupama se javio u 47\%, a miješano, u oba navedena oblika, u $32^{*}$ slucajeva.

Ponik se javio na $42 \%$ položenih primjernih krugova.

\section{PROIZVOD IN I T I POVI SU U A}

Izdvojenim osnovnim tipovima suma nastojali smo da uzmemo uobzir sve ekološke razlike za koje smo pretpostavljali da mogu biti od uticaja na proizvodnost staništa. Osnovni tipovi šma sličnih ekoloških karakteristika odnosno proizvodnih mogucnosti $i$ sa istim ciljen gazdovanja su objedinjeni u jedan proizvodni. Na taj način su formirane jedinice proizvodne klasifikacije šuma. Ekološke i proizvodne karakteristike ovih jedinica date su u okviru osnovnih tipova šuma iz kojih su komponovani proizvodni. S obzirom da su ovin proširena variranja pojedinih ekoloških i proizvodnih svojstava, kod gazdovanja ovim šumama za svaki proizvodni tip nogu se uzeti u obzir specificnosti uturdjene kat osnovnih tipova suma.

Izdvoienim i definisanim osnovnim tipovima suma utvrdili smo postojece stanje. Radi racionalnog kor iscenja sumskih stanista potrebn je istakruti i potencijalne mogucnosti pojcdinih stanista i ograniçavaju ce fakture pri tretiranju pojedinih tipova lato je iadvojenin proizvadnim tipovima data i ovakva interpretacijo.

Kod izbora vrsta drveca, omjera smjese, sistema gazdovarja , vodilo se racuna o ekološkim svojstvina osnovmih tipova iz kojih su formirani proizvodni tipovi suna, rjihovim sindinamskin karakteristikanta, kao i biološkim svojstvima vrsta drvęa kojo su zastupljene $i$ onih koje mogu doci u obzir da bi se postigan najveci i najuredniji prinos $i$ očuvala ekoloska ravnoteža staništa.

Od datill preporuka za pojedine proizvodne tipove suma noguca su odstupanja shodno konketuin lokalnim uslovina, a cema ce se donositi odluka za svaki konkretni sluçaj

Pri izbor. najpodesnijeg sistena gazdovanja koristili smo sugestije predlosene u radu $M$ a $t$ i $c$ a et al. (1969). 
Procjena velizine prinosa $i$ drugih taksacionih elemenata kreiranih proizvodnih tipova šuma, vršena je, za bijeli bor i smrču prema prirasno-prihodnim tablicama $w i$ e $d$ e m a $n n a$.

Razmatrajuci mogućnosti, ograničenja $i$ opasnosti vezane za zemljiste, istakli smo moguchosti povecanja plodnosti zemljista fertilizaci. jom, upasnosti od erozije zem\}jista, zakorovljavanja, zatravijivanja, vjetroizvala, formiranja nepovoljuih furmi hamusa, pozara, flogucnosti primjene mehanizacije i druge specifjcho momento za pojedine proizvodne timue s̆lı ר.

S obzirom da izvjestan broj osnovnih tipova šma ni.je obradjen, - zoog male zastupljenosti, navedeni su kod pojedinih proizvodnih tipova ziji se cilj gazdovanja može primijeniti i ha ove reproučere ostuve aipow simat.

Subalpiske štme smrče nisu obuhvaćne u ovon radu jer hi: pripadaju klimaregionalnom pojasu suma bukve i jele. Medjutim, da bi se śtu više suzio prostor za neadekvatno tretiranje sastojina ovih suma, kao $i$ zbog potreba tipoloških kartiranja, za ove šume se mogu primijeniti opisani ciljevi gazdovanja predvidjeni za odgovarajuce proizvodne tifiove brdskih šuma smrč s kojima su ekološki vrlo bliske.

Iza pregleda formiranih proizvodnih tipova šma date su kare:teristike svakog od njih.

\section{PREGLED FROIZVODNIH TIPOVA SUM}

\section{SUUME SMRČE | BIJELOG BORA, JELE I SMRČE, SMRC̈E*}

A. $\$$ ume smree $i$ bijelog bora

$$
V I-a-1,3
$$

1. Sume smrče i bijelog bora na kalkomelanosolu i plitkom kal. kokambisolu.

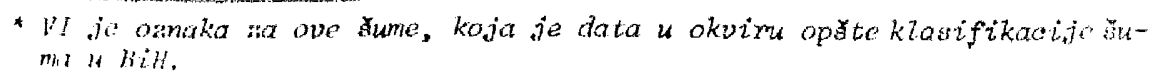


VI $-a-2$

2. Suma smrče i bijelog bora na dolomitnoj rendzini.

$V[-a-4,5$

3. Sune smrce i bijelog bora na dubokom kalkokanbisolu i luvisolu na krecrijaku $i$ dolomitu.

$V\{\cdots i+\gamma$

4. Sume smrce i bijelog bora na duboknam districnom kantsisola.

B. sumeje le i smroe

$V ! \cdots b \cdots 1,2$

1. Stune jele i smrče kalkomelanosolu i plitkon kalkokanbisolu.

$V(-b-3,1$

2. Sume jele $i$ smrce na dubokum kalkokanbisolu i luvionlu ru krecrijaku i dolomitu.

$V I=b-6,7,8$

3. Sume jele i smrče na dubokon distričnom kanbisolu, luvisolu i pseudogleju na kiselim silikatnim stijenama.

C. ริumesmrot

$V I-c-1,3$

1. Sume smrč na kalkomelanosolu i plitkom kalkokambisolu.

$\mathrm{VI}-\mathrm{C}-4,5$

2. Sume smrče na dubokom kalkokambisolu i luvisolu na krec̆njaku i dolomitu.

$V I-c-7,8,9$

3. Sume smrče na dubokom distričnom kambisolu, luvisolu i pseudogleju na kiselim silikatnim stijenama. 


\section{KARAKTERISTIKE PROIZVODNIH TIPOVA SUMA}

\section{V'l SUME SMRČE I BIJELOG BORA, JELE I SMRČE I SMRČE}

A. sume smrce i bije 1 og bor a

PROIZVODNI TIP: VI-a-1,3

\section{SUME SMRCE I BIJELOG BORA NA KALKOMELANOSOLU I PLITKOM KALKOKAMBISOLU}

Ovim proizvodnim tipom sume obuhvačena su dva osnovna tipa mjesovitih šuma smrče i bijelog bora: na kalkomelanosolu i plitkom kalkokambisolu. S obzirom na površinu oba osnovna tipa zastupljena su podjednako, sa oko 1580 hektara, tako da ukupna površina suma ovoga proizvodnog tipa izrosi oko 3160 hektara.

Razlog za spajanje ova dva osnovna tipa šma u isti proizvodni tip su njihove približno iste ekološko-vegetacijske i razvojno-proizvodne karakteristike. U oba slučaja radi se, naime, o zemljištima koja, s obzirom ra prinosni potencijal, zbog poznatih razloga (plitkost, kamenitost, kserotermnost) spadajt u losija i sumama koje predstavljaju jedan stadij u sukcesivnom nizu razvoja vegetacije koji ide prema sumama jele, smrće, (bukve). Oba osnovna tipa nalaze se u razliçitim fazama toga razvoja, a rajcesce u terminabroj.

I s obzirom na osnowne geomorfoloske karakteristike (nadmorskll visinu, akspoziciju i inklinaciju) ova dva osnovna tipa šma se hitnije ne: razlikuju. Prosječna nadmorska visina suma smrče i bijelog bora na kalkumelanosolu iznosi oko $1240 \mathrm{~m}$, a na plitkom kalkokambisolu oko 1210 m. Prosieça inklinacija terena prvih je oko 13, a drugin oko 10 stepeni. tha osnovna tipa nalaze se na svim ekspozici.jama podjednako.

I u pogledu boniteta staništa, ocijenjenom na bazi visina stabala, takodje nisu konstatovane praktično znaćajne razlike iznedju ova dva osnowna tipa šma. Razlike su u prosjeku manje od $1 / 2$ bonitetrog razredi kada su u pitanju smrca i jela. Istina, za bijoli bor ta razlika je $i$ nesto veca, ali je $i$ ona u prosjeku manja od amplitude jednog bonitet noil iazreda 
Medjutim, u poyledu veličine zalihe i zapreminskog prirasta ova dva osnouna tipa suma se znatno razlikuju. Prosječna zaliha sveukupnedr. vie mase po hektaru manja je $u$ šumama na plitkom kalkokambiso) " (236 $\mathrm{m}^{3} / \mathrm{ha}$ ) nego $u$ šumama na kalkomelanosolu $\left(274 \mathrm{~m}^{3} / \mathrm{ha}\right)$ iako bi, sobzirom $\mathrm{nt}$ osobine zemljišta, trebalo da bude obratno. Slična je situacija i u ponledu velicine zapreminskog prirasta. Godisnoji zapreminski prirast suma m kalkomelanosolu iznosio je u doba mjerenja $7,11 \mathrm{~m}^{3} / \mathrm{ha}$ ) a cuma na plick kalkokambisolu $4,95 \mathrm{~m}^{3}$ po hektaru.

Ovako velike razlike u efektivnoj produktivnosti izmedju ova dva osnovna tipa šund su u prvom redu posljedica razlicitog stepena is.. korišcenosti proizvodnog prostora. If sumama na kalkomelanesolu proizvirini prostor se u prosjeku daleko bolje karisti nego a sumana na plikkom kalkokambisolu o cenu svjedoče i podaci o prosječnom stepenu sklopa wra dva osnovna tipa suma. Naime, prosječni stepen sklopa suma na kalkomelam nosolu iznosio je $0,62 \pm 17 \%$, a suma na plitkom kalkokambisolusvega 0,4 ? $\pm 39$.

Kvalitet zalihe, $u$ pogledu tehnicke upotrebljivosti njenih stabala, zadovoljava. U oba osnovna tipa udio prve i drugf tehmicke kvali. tetne klase iznosi preko 80 procenata.

Prirodno obnavljanje ovih šuma je dosta slabo $i$ odvija se veoma sporo, uglavnom zbog znatne zakorovljenosti zemljišta.

\section{CILJ GAZDOVANJA}

Kao što je naprijed navedeno u ovom slučaju se radi o šmman: koje predstavljaju jedan stadij u sukcesivnom nizu razvoja vegetacijekoji ide prema šmana jele, smrče i (bukve). Uvažavajući, prema tome, prirodni razvoj ovih šuma, kao i činjenicu da se $u$ datim stanišnin uslovina jelom, smrčom i (bukvon) ostvaruju relativno visoki i kvalitetni prinosi. trebalo bi u procesu gazdovanja sumama ovog proizvodnoga tipa tezista staviti na postepeno formiran,je mješovitih raznodobnih sastojina $j e l a$, sinrče $i$ (bukve) težeči da prosječni omjer smjese bude: jela 0,60, smrče 0,$30 ;$ bukve 0,10 . Jela $i$ smrča treba da imaju karakter glavnih vrsta, a bukva bi imala prvenstveno biološku ulogu.

Polazeči od sadašnjeg starja u razvoju suma ovoga proizvodnisga tipa s jedne, te datih stafijoih uslova i bioloskih osobina jele, sallria 
i bukve s druge strane, postavijeni cilj bi se najefikasnije realizovao kada bi se $j$ u ovom proizvodnon tipu sume primijenio skupinasto-preborni sistem gazdovanja. Za ovaj sistem gazdovanja odgovarao bj sljedeci normalni sastav ovih šuma, pri taksacionoj granici od $10 \mathrm{~cm}$ :

- vrste drveća $i$ omjer smjese: jela 0,60 , smrča 0,30 i bukva 0,10

- bonitetni razred stanista ocijenjen na bazi visina stabala: jele i smrče III, a bukve IV.

- maksimalni stepen sklopa na kraju desetogodišnjeg turnusa: 0,70 ,

- srednji prečnik stabala sastojine u sredini turnusa: za jelu oko $25 \mathrm{~cm}$, smrču oko $24 \mathrm{~cm}$ i bukvu oko $22 \mathrm{~cm}$,

- maksimalni (završni) debljinski stepen do koga ce se uzgajati stabla: jele i smrče $70 \mathrm{~cm}$, a bukve $60 \mathrm{~cm}$.

Sastojine ovih taksacionih karakteristika inale bi sljedecu normalnu zalihu u sredini turnusa:

\begin{tabular}{|c|c|c|c|c|}
\hline Vrste drveca: & jela & snirča & bukvä & $\begin{array}{c}\text { wupno } \\
\text { m/1ha }\end{array}$ \\
\hline Krupuog drveta & 180 & 90 & 30 & 300 \\
\hline Sveukupne drune mase & 215 & 105 & 36 & 356 \\
\hline
\end{tabular}

Pri ovakvom norma lnom sastavu moz̈e se u šumama ovoga prolzvodano lipa ostvariti prinos u visini sljedeceg godisrjeg zaprenintogprirasta:

$\begin{array}{lcccc}\text { Vrste drveca: } & \text { jeta } & \text { smrža } & \text { bukva } & \begin{array}{r}\text { ukupno } \\ \mathrm{m} 3 / \text { ha }\end{array} \\ \text { Kruphog drveta } & 5,9 & 2,8 & 0,4 & 9,1 \\ \text { Sveukumo drune mass: } & 7,0 & 3,2 & 0,5 & 10,7\end{array}$

PROIZVODNI TIP: VI-a-2

SUME SMRCE I BIJELOG BORA NA DOLOMITNOJ RENDZINI

Zbog specificnih ekolosko-veratacijskin i razvojno-proizvodnih karakteristika šme surce i bijelog tert ra folonituh rendzinama su $i z-$ 
dvojene u poseban proizvodni tip.

Radi se zapravo o veoma plitkim, pjeskovitim, relativno suvimi veoma karbonatnim zemljištima, koja su uz to jako siromašna hranjivimmaterijama, tako da im je primarni potencijal dosta nizak. Mjerama fertilizacije on se ne može zračajnije poboljšati. Eroziji nisu podložna, ali su jako podložna zakorovljavanju $i$ postoji opasnost od stvaranjabazičnog sirovog humusa.

Ukupna površina šuma ovoga proizvodnoga tipa je oko 1430 hektara. Najviše su zastupljene u području Kupresa. Javijaju se na svim ekspozicijama, nešto češce na zapadnim i južnim. Prosječni nagib terena im je oko 12 stepeni, a prosječna nadmorska visina oko 1210 metara.

Prosječna zaliha šuma ovoga proizvodnoga tipa, iskazana sveukupnom drunom masom na bazi taksacionog praga od $5 \mathrm{~cm}$, iznosila je u momentu mjerenja oko $213 \mathrm{~m}^{3}$ po hektaru (smrče $105 \mathrm{~m}^{3}$ ili $49,5 \%$, hijelog bora $107 \mathrm{~m}^{3}$ ili 50\%, bukve $\mathrm{i}$ ostalin liscara $1 \mathrm{~m}^{3}$ ili $0,5 \%$.

Tekuci godišnji zapreminski prirast ove zalihe iznosio je 7,07 $\mathrm{m}^{3}$ po hektaru (smrče 3,84 ili 54\%, bijelog bora 3,16 ili $45 \%$, bukve $i$ ostalin lišcara $0,07 \mathrm{ml}^{3} \vdots 1$ i $1 \%$ ).

Bonitetrif razred stanista, ocijenjen na bazi visine stabala, iznosio je u prosjeku i za smrcu i bijeli bor Ill,9, a bukvu i ostale 7 išcare III,0. Bonitet staništa za bukvu i ostale liscare nije pouzdano ocijenjen zbog njihovog malog učs sca.

Kako se iz podataka vidi efektivna produktivnost šma ovoga proizvodnog tipa je prilicho visoka $u$ odnosu na prinosni potercijal stairsta. Razlog tome je, u prvom redu taj što se radi o šumama koje su po strukturi veoma bliske jednodobnim sastojinarna, a nalaze se, uglavnom, u periodu kulminacije tekuceg zapreminskog prirasta.

Kvalitet zalihe, s obzirom na tehnicku upotrebljivost njenih stabala, je dobar. Relativno visok $(58,3 \%)$ udio prve tehnicke kvalitetne klase stabala bijelog bora ukazuje na mogućnost uzgoja veoma kvalitetnih stabala ove vrste na ovin stanistima.

Kvalitet podmlatka i stanje podmladjenosti šma ovoga proizvo* droga tipa ne zadovoljava. 
Sobzirom da se radi o specifičnim stanišnim uslovima, koji najbolje odgovaraju bijelom boru i smrči, predlaže se da u šmama ovoga proizvodnoga tipa bijeli bor $i$ smrča $i$ dalje ostanu jedine vrste drveća sa kojina ce se gazdovati.

IJ cilju nkaksimalnog korišcenja prinosmog potencijala kako stapišta tako i navedenih vrsta drveca, kao i radi uzgoja što vecen broja kvalitetnin stabala, to jest radi trajnog povecanja prinosa i poboljsanja njegovog kvaliteta, preporučuje se formiranje mješovitin sastojina smméc i bijelog bora grupimicne strukture u kojima bi po novršini bijeli bor učestrovao sa 0,4 , a smrá sa 0,6 . Jdjeli pojedinih vrsta (po povrsini) unutar pojedinin lokaljteta $i$ velicina skupina treba da zavise u prvoli redu od zatečenog sastava ovih suma i mikrostanišnih uslova, a ne od navedene proporcije.

Polazeçi ud sadašnjeg sastava ovih šuma predvidjeni cilj bi so najlakše ostvario skupinastim sistemom gazdovanja na bazi planskog produkcionog perioda od 120 godina $i$ za snrču i za bijeli bor i opšteg podmladnog razdoblja od 40 godina za bijolj bor $i 60$ za smrčli.

Skupine bi se po pravilu obnavljale vjestacki, sadnjom jakih, školovanih sadnica bijelog bora $i$ smrće. U cilju izbjegavanja ranih proreda treba primjenjivati rjedju sadnju.

Uz navedene elemente cilja gazdovanja i uslov da ce stabla bijelog bora dostizati visine koje u prosjeku odgovaraju trecem, a smrio ceturtom bonitetnom razredu može se očekivati da ce se u sastojinana ovoga proizvodroga tipa, uz primjenu unjerenih proreda, noći proizvesti ukupno (sa prorednim materijaloni) po hektaru oko $220 \mathrm{~m}^{3}$ krupnog drveta bijelog bora i oko $400 \mathrm{~m}^{3}$ krupnog drveta smrče.

Prema tome, prinos (prosječni dobni zapreminski prirast ukupro proizvedenog drveta) iznosio bi po hektaru oko $2,0 \mathrm{~m}^{3}$ krupnog drveta bijelog bora i oko $3,3 \mathrm{~m}^{3}$ krupnog drveta smrče. 


\section{SUME SMRCE I BIJELOG BORA NA DUBOKOM KALKOKAMBISOLU I} LUVISOLU NA KRECNJAKU I DOLOMITU

ovim proizvodnim tipom obuhvacena su dva osnovna tipa mjořcovitih šuma smrče i bijelog bora na krečnjačko-dolomituim stijenamd: na dubokom kalkokambisolu i na luvisolu. Radi se, naime, o dva tipa zemljišia koja, kako je već istaknuto $i$ pored kvalitetnih razlika, pokazujupribliżno iste proizvodne karakteristike i koja s obzirom na prirodni potencijal spadaju u bolja.

Ukupna površina šuma ovoga proizvodnoga tipa je oko 3460 hekta ra. U tome sume na dubokom kalkokambisolu participiraju sa oko 1560 hektara ili 45 procenata, a šme na luvisolu sa oko 1900 hektara 17 i 55 procenata.

Zastupljene su na malim površinama unutar pojasa šma jele,smrče (bukve). Najcesćce se nalaze na toplijim ekspozicijama. Prosječni nagib terena krece se od 5 do 10 stıpeni, a prosječna nadmorska visina od $1208 \mathrm{~m}$, za šume na luvisolu, do $1220 \mathrm{~m}$, za šume na dubokom kalkokanbiso1u.

Prosjec̆na zal iha sveukupne drune mase, izračunata na bazi tak sacionog praga d $5 \mathrm{~cm}$, iznosila je, u momentu mjerenja, u šmania ra dubokom kalkokantisolu oko $310 \mathrm{~m}^{3}$ po hektaru (jele $29 \mathrm{~m}^{3}$ ili $9 \%$, smrče 140 in $^{3}$ il i $45 \%$, bijelog bora $141 \mathrm{~m}^{3}$ ili $46 \%$ ), a u sumama na dubokom luvisolu oka $320 \mathrm{~m}^{3}$ po hektaru (jele u tragovima, smree $218 \mathrm{~m}^{3}$ ili $68 \%$, bijelok bora $102 \mathrm{~m}^{3}$ ili $32 \%$ ). Prema tome, izmedju osnovmin tipova suma koji su obuhvaceni ovim proizvodnia tipom nisu konstatovane znacajne razlike u velicini zalihe.

I u pogledu boniteta staništa, ocijenjenog na bazi visine stabala smrça i bijelog bora, nema znaçajnih razlika izmedju ovadva osnovna tipa sumo. Frosjecrni bonitetni razred staništa, ocijenjen na bazi visina stabala smrce $i$ bijelog bora iznosio je u sumama na dubokom kalkokambisolu: za smrcu III, 1 , bijeli bor II,7 i jelu II,0, a u sumama na luvisolu: Zä simrču III, 0 , bijeli bor II, 5 i jelu III, 0 .

Boritet stanista za jelu nije pouzdano ocijenjen zbog njemog ma log učešça. 
Medjutim, uprkos ovome, konstatovane su dosta velike razlike $u$ efektivnoj produktivnosti izmedju ova dva osnouna tipa suma.

Tekuci godišnji zapreminski prirast sveukupne drvne mase sumit na dubokom kalkokambisolu iznosio je 6,7\%, a šma na iuvisolu samo 2,96 $\mathrm{m}^{3}$ po hektaru. Ovako mali zapreminski prirast suma na luvisolu pos ljedica je, u prvom redu, njihovog veona niskog stepena sklopa. Naime, prosjecni stepen sklopa suma na luvisolu iznosio je u momentu mjerenia salan $0,35 \pm 41 \%$. To zapravo zraci da u ovom osnovnom tipu suma $65 \%$ proizvotmog prostura nije iskoristeno za produkciju drvne mase. Istovremeno, prosicuini stepen sklopa suma na dubokon kalkokambisolu iznosio je 0,6? in.

Podmladjenost ova dva osnovna tipa sumb takodje nije ujednacein. Ona u potpunosti zadovoljava, i po broju i po kvalitetubiljaka, keta su u pitanju sulle na dubokom kalkokambisolu, za razliku od suna ta luvi. solu u kojima je proces regeneracije veoma slabo izrazen, i advijuse vecma sporo, uglavnom zbog zatravljenosti i zakorovljenosti zemljista.

Kvalitet zalihe, s obzirom na tehmicku upotrebljivost njenit stabala je veoma dobar u oba osnovna tipa suma. Veliki udio prve i drug? tehnicke kvalitetne klase u zalihi oba osnovna tipa (iznosi oko $90 \%$ ) u" kazuje da se i u šunama ovoga proizvodnoga típa može ostvariti prinos $i$. zuzetnog kvaliteta.

\section{CILJ GAZDOVANJA}

4 ovom slučaju radi se o zemijištima koja imaju dosta visok. prinosni potencijal i sumama koje predstavljaju jedan stadiju sukcesivnom nizu razvoja vegetacije, koji (razvoj) ide prema sumama jele, smrče $i$ bukve. Nalaze se u razlicitim fazama toga razvoja, a najčsçce u terminalnoj.

Pošto je efektivna produktivnost šuma ovoga proizvodnoga tipa dosta niska u odnosu na prinosni potencijal staništa treba u procesu gazdovanja oviı šumama težište staviti, u prvam redu, na popravljanju postojeceg lošeg stanja i maksimalnom korišcenju prinosnog potencijala staništa, tj. na trajnom povećanju prinosa $i$ poboljšanju njegovog kvaliteta. Radi toga, kao i radi povecanja stabilnosti produkcije, treba, uvažavajuci prirodni razvoj ovih suma, postepeno formirati mješovite raznodobne 
Sastojine jele i smrče sa nešto bukve i plementih liscara.

Predvidjeni cilj bi se najefikasnije ostvario ako bi se printjenio skupinasto-preborni sistem gazdovanja, koji svojam fleksibilmosu, omogucuje da se, respektujuci is tovremeno zateceno stanje u razvoju sis. tojind $i$ date prirodno-radne uslove, u najkracen mogucen vremenu filit.imalno poveca prinos $i$ poboljsa njegov kvalitet uz istovremeno ostivacuin najpovoljuijih ekononckin efrokata.

Skupinas to-prebornim sistemom gazdovanja trebato bi fumirit.i mjeśovite raznodobne sastojine jele, smrce (bukve) sa sljedecin ulmen. tima nomalrog sastava, uz desetogudisnji turnus $i$ taksacioni prag an 10 cin:

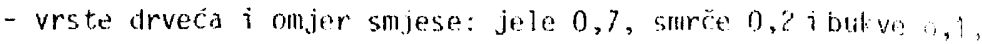

- bonitetni razred stanista, ocijenjer ra bazi visind stabnha: za jelu i smrču 11,5 , a bukvu $I 11,0$,

- maksimalni stepen sklopa sastojine na kraju turnusa: 0, 14.

- maksimalni (zavrsni) debljinski stepen do korga co so azgaja

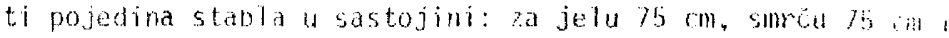
bukva $70 \mathrm{chl}$,

- srednji prečnik stabala u sastojini u sredini turnusa za jeTu oko $26 \mathrm{~cm}$, smiru oko $25 \mathrm{~cm}$ i bukvu oko $23 \mathrm{~cm}$.

Uz ove elemente normalna zaliha u sredini turnusa bi iznosila:

$\begin{array}{lcccc}\text { Vrsta drveca: } & \text { jela } & \text { smrc̆a } & \text { bukva } & \begin{array}{c}\text { ukupho } \\ \mathrm{m}^{3} / \mathrm{h} \text { : }\end{array} \\ \text { Krupnog arveta } & 245 & 70 & 36 & 351 \\ \text { Sveukupne drvne mase } & 290 & 83 & 42 & 415\end{array}$

Ovakvim sastavom ostvarivace sastojine ovoga proizvodnoga tipa šme tekuci godišnji zapreminski prirast, odnosno prinos:

Vrsta drveca: jela smrča bukva ukupno

$\begin{array}{lllll}\text { Krupnog drveta } & 7,2 & 2,1 & 0,6 & 9,9\end{array}$

$\begin{array}{lllll}\text { Sveukupne drvne mase } & 8,4 & 2,4 & 0,7 & 11,5\end{array}$ 
SUME SMRCE I BIJELOG BORA NA DUBOKOM DISTRICNOM KAMBISOLU

Ovaj proizvodni tip suma identican je osnovnom tipu istoga naziva.

Sume smrče i bijelog bora na dubokom distričnom kambisolu na kiselim silikatnim stijenama izdvojene su u poseban proizvodni tip,u prvom redu, zbog toga što su u pitanju zemljišta izrazito povoljnih ekoloskih karakteristika. Radi se zapravo o razlicitim varijetetima zemljista (u zavisnosti od prirode maticnog supstrata) koja se odlikuju velikom dubinom fiziološki aktivnog profila i povoljnog su mehanickog sastava.Imaju dosta visok prinosni potencijal kojj se može značajno povecati fertilizacijom, narozito fosforom $i$ azotom ( $c$ i $r$ i $C$, 1971). Slabo su skeletna $i$ male poursinske kamenitosti pa je mogucnost primjene mehanizacije u procesu gazdovanja veoma velika. Podložnost eroziji je srednja, dok je opasnost od vjetroizvala prilično izražena. Ukoliko se sklop jače prekine postoji opasnost od zakorovljavanja kupinom $i$ bujadi ako se radi 0 glinovitim varijantama, a horovnicom ako su u pitanju pjeskovite varijante. Na pjeskovitim varijantama dolazi do obrazovanja sirovog humusa znatre mocnosti.

Ukupna površina šuma ovoga proizvodnoga tipa je oko 1110 hektara. Nalaze se na svim ekspozicijama, a najčšce na južnim. Prosječna nadmorska visina im je oko $1010 \mathrm{~m}$, a nagib terena oko 18 stepeni.

Bonitetni razred staništa, ocijenjen na bazi visina stabala, iznosio je u prosjeku: za jelu IIl,0; smrču II ,8, bijeli bor II 2 i bukvu III, 7 .

Pri taksacionom pragu od $5 \mathrm{~cm}$ i prosječnom stepenu sklopa od 0,68 , prosječna zaliha sveukupne drvne mase suma ovoga proizvodnoga tipa iznosila je u doba mjerenja $372,3 \mathrm{~m}^{3}$ po hektaru. Smrča je u njoj učestvovala sa 49 procenata, bijeli bor sa 46 procenata, jela sa jednim procentom i bukva sa dva procenta.

Godisnji zapreminski prirast ove zalihe iznosio je $12,5 \mathrm{~m}^{3}$ po nek toru (smrce $7,21 \mathrm{~m}^{3} /$ ha, bijelog bora $4,75 \mathrm{~m}^{3} / \mathrm{ha}$, jele $0,21 \mathrm{~m}^{3} /$ ha $i$ bukve $\left.0,18 \mathrm{~m}^{3} / \mathrm{ha}\right)$.

$4 \%$ 
U odnosu na ostale osnovne tipove śuma koji su obuhvaceni ovim istraživanjima, ovaj proizvodni tip ima najvecu efektivnu produktivnost. Produktivnost je istovremeno odraz povoljnih stanišnih uslova, s jedne $i$ strukturne izgradjenosti suma ovog proizvodiog tipa,s druge strane. Radi se zapravo o šumama koje, s obzirom na strukturnu izgradjenost. (raspodjelu stabala po debljinskim i visinskin stepenima), imaju izgled jednodotnih sastojina koje se nalaze u periodu kuiminacije tekuceg Lāpreminskor prirasta. Naime, skoro $80 \%(78,9 \%)$ sveukupne zalihe suma ovoga proizvidnoga tipa otpada na zalihu stabala debljinske klase 20 do $50 \mathrm{~cm}$, koja se (stabla), kako je poznato, nalaze u periodu velikog zapreminskog mrirasta $\mathrm{itj}$ pred tim periodom.

Kvaljtet zalihe u pogledu tehnicke upotrebljivosti njenih stabala je, kada su u pitanju jela, smrca i bijeli bor, veoma dobar, a veoma loš kada je u pitanju bukva i ostali lišćari. Udio prve i druge tehnicke kvalitetne klase u zalihi jele je $100 \%$, smrče $92,8 \%$, bijelog bora $93,1 \%$ a bukve i ostalih lišcara (zajedno) samo $20,7 \%$.

Stepen podmladjenosti suma ovoga proizvodnoga tipa u potpunosti zadovoljava kako po broju tako i po kvalitetu biliaka, kada su u pitaniu jela, smrča j bukva, dok se bijeli bor praktično prirodno ne obravlja.

\section{CILJ GAZDOVANJA}

Kako je već istaknuto u ovom slučaju radi se o visoko produktiunim zemljištima na kojima se nalaze takodje visoko produktivne sume smrče $i$ bijelog bora čiji prirodni razvoj ide prema takodje visokoproduktivnim sumama jele, smrče i bukve.

Prema tome, u procesu gazdovanja ovim sumama težište treba staviti,u prvom redu, na ocuvanju njihove efektivne produktivnosti i poste. penom formiranju mješovitih raznodobnih sastojina jele, smrče i bukve. $S$ obzirom na stanišne uslove, dosta mezofilne prilike i obilje svjetlosti, kao $i$ predvidjeni sistem gazdovanja, postoje mogućnosti i za forsiranje plemenitin lišcara.

Polazeci od trenutnog stanja u razvoju suma ovoga proizvodroga tipa i njihove strukturne izgradjenosti, a uvažavajuci upotpunosti princip kontinuiteta produkcije, predvidjeni cilj bi se najefikasnije reatizovao ako bi se i u Šumama ovoga proizvodnoga tipa primijenio skupina t:. 
-preborni sistem gazdovanja.

Za buduće mješovite sastojine jele, smrče i bukve uz taksacionu granicu od $10 \mathrm{~cm} i$ uslov da ce stabla jele $i$ smrče dostizati visine koje odgovaraju u prosjeku drugom, a stabla bukve trecem bonitetnom razredu, elementi normalnog sastava bili bi sljedeci:

- vrsta drveća i omjer smjese: jela 0,7 , smrča 0,2 , bukva 0,1 ,

- maksimalni stepen sklopa sastojine na kraju desetogodišnjeg turnusa: 0,74 ,

- maksimalni (završni) debljinski stepen do koga ce se uzgajati stabla: jele $75 \mathrm{~cm}$, smrče $75 \mathrm{~cm}$, bukve $70 \mathrm{~cm}$,

- srednji prečnik stabala sastojine u sredini turnusa: za jelu oko $22 \mathrm{~cm}$, smrču oko $26 \mathrm{~cm}$ i bukvu oko $23 \mathrm{~cm}$.

Pri ovakvim taksacionim elementima normalna zalina $u$ sredini turnusa bi iznosila:

Vrsta drveća: jela smiča bukva ukupno

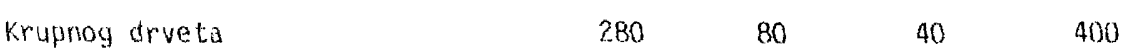

$\begin{array}{lllll}\text { Sveukupne drvne mase } & 335 & 95 & 48 & 473\end{array}$

ovakvin normainin sastavom może se u šumana ovoga proizvodnoga tipa ostvariti sljedeci tekuci godisnji zapreminski prirast, odnosno prinos:

Vrsta drueca: jela smrča bukva ukupno

Kruprog drveta

$7,6 \quad 2,2$

0,6

10,4

Sveukupne drune mase

$8,8 \quad 2,6$

0,7

12,1

cilj gazdovanja predvidjen za ovaj tip sume može se primi ieniti na sljadece osnovre tipove suma: sume smrce i bijelog bora naplitkon districrom kambisolu (VI-a-6): sume smrce i bijelog bora na luvisolu nasilikatnim stijenama (VI-a-8); sume smóte i bijelog bora na pseudogleju $(v) \cdot a \cdot 9)^{\star}$.

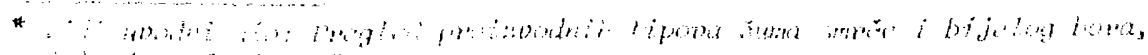




\section{B. $\check{s} u m e j e l e j s m r \check{c} e$}

PROIZVODNI TIP: VI-b-1,2

\section{SUME JELE I SMRCE NA KALKOMELANDSOLU I PLITKOM KALKOKAMBISOLU}

Ovim proizvodnim tipom obuhvacena su dva osnovna tipa šuna jele i smrče na krečnjačko-dolomitnim stijenama: na kalkomelanosolu i na plitkom kalkokambisolu.

I u ovom slučaju radi se o dva tipa zemljišta koja i poredkvalitativnih razlika u osobinama u rezultanti pokazuju približno iste ekološko-proizvodne karakteristike. Plitka su (dubinama in najčescce varira $u$ intervalu od 20 do $40 \mathrm{~cm}$ ), i znatne su površinske kamenitosti. zbogmale dubine $i$ velike kamenitosti ograničena je upotreba mehanizacije pri sumsko-uzgojniil radovima. Nisu porložna eroziji, ali postoji opasnost od zakorovijavanja gramineama. Opasnost od vjetroizvala je srednje izrażena. $\$$ obzirom na prinosni potencijal spadaju u lošija. Mjerana fertilizacije prinosna sposobnost in se ne može bitnije povećati zbog faktora koji to ograničavaju (plitkost i kamenitost).

Ukuprã pouršina suma ovoga proizvodnoga tipa je oko 12820 hektara. U tome šume na kalkomelanosolu učestvuju sa oko 7120 hektara ili 56 procerata, a šme na plitkon kalkokambisolu sa oko 5700 hektara ili 14 procenta.

ramedju ova dva osnovna tipa šuma takodje ne postoje značajne razlike u pogledu nadmorske visine, ekspozicije i inklinacije.

Prosječna nadmorska visina suma na kalkomelanosolu je oke: 1200 III, a šuma na plitkom kalkokambisolu oko $1240 \mathrm{~m}$. Prema tome, pros ječna radmorska visina suma ovoga proizvodnoga tipa je za oko $100 \mathrm{~m}$ visa od prusjeçne nadmorske visine prethodnog proizvodnog tipa suma jele i sinrce lld dubokon kalkokambisolu i luvisolu. nsim toga u šmana ovoga proizvadnciga tipa tereni su nešto veceg nagiba od nagiba terena suma urethodnog proizvodioga tipa.

Prosiecni majib terena suma na kalkomelanosolu iznosi 14 a sulla no plitiom kalkokambisolu 11 steperi. 
Ni s obzirom na sastav. vrsta drveća i njihov medjusobni odnos nema praktično značajnih razlika izmedju šuma na kalkomelanosolu i šuma na plitkon kalkokambisolu.

Pri taksacionoj granici od $5 \mathrm{~cm}$, prosječna zaliha šuma na kalkomelanosolu iznosila je u doba mjerenja $358 \mathrm{~m}^{3}$ po hektaru sveukupne drvne mase ( $53 \%$ jele, $44 \%$ smrče, $3 \%$ bukve $i$ ostalih lišcara), a suma na pli tkom kalkokambisolu $315,5 \mathrm{~m}^{3}$ po hektaru (54\% jele, $45 \%$ smrče, $1 \%$ bukve $j$ ostal ih lišcara). Tekuci zapreminski prirast sveukupne drune mase šmō na kalkomelanosúlu iznosio je $7,27 \mathrm{~m}^{3}$ po hektaru, a na plitkonkalkokambisolu $4,99 \mathrm{~m}^{3}$ po hektaru.

Prilično velike razlike u velicini tekučg godišnjeg zapreminskog prirasta, tj. u efektivnoj produktivnosti, izmedju ova dva osnovna tipa suma su \# prvom redu posijedica njjihovog različjtog sastava i strukturne izgradjenosti a ne razlicitog prinosnog potencijala. Naime, zapremina stabala debljinske klase sa $70 \mathrm{~cm}$ bila je u šumama na kalkonelanosolu za oko $30 \%$ veca od zaprenine stabala te debljinske klase u sumama na plitkom kalkokambisolu. Isto tako i prosječni stepen sklofa suma na kalkomelanosolu $(0,65)$ bio je veci od stepena sklopa ovih šma na plitkom kalkokambisolu $(0,57)$.

Inace, kada se zapreminski prirasti ova dva osnovna tipa suma svedu na iste ostale uslove (isti sklop. istu velicinu i debljinsku strikturu zaline) razlike praktično nestaju. Kako je i bonitet staništa oci jenjen na bazi visina jelovih $i$ smrčevih stabala u oba osnouna tipa skoro isti (iznosio je u Sumama na kalkomelanosolu: za jelu II,8, smréu III, 4, bukvu i ostale lišcare III,8, a na plitkom kalkokambisolu:za je]u II,9, za smrču 111,5 , bukvu $i$ ostale lišcare IV,0) realno je očekivati da su $i$ razlike u prinosnom potencijalu ova dva tipa zemljišta udatim klimatskim uslovima, ukoliko postoje, toliko male da sa prakticnog stanovišta ne bi bilo opravdano njihovo razdvajanje u posebne proizvodne tipove.

U pogledu uslova obnavljanja $i$ same podmiadjenosti takodje nema razlike izmedju ova dva osnovna tipa suma. Stanje podmlatka u potpunosti zadovoljava kaka s obzirom na broj tako is obzirom na kvalitet biljaka.

I kvalitet zaliha, s obzirom na tehničku upotrebljivost njenih stabala, zadovoljava $i$ približno je isti u oba osnovna tipa కuma. Stabla prve $i$ druge tehnicke kvalitetne klase ucestvuju u zalihi suma na kalko- 
melanosolusa 78,7 procenata, a u కumama na plitkom kalkokambisolu sa 77,7 procenata.

\section{CILJ GAZDOVANJA}

I u šumama ovoga proizvodnoga tipa, zbog iznijetih razloga, jela $i$ smrca treba $i$ dalje da ostanu glavne vrste drveca, a bukva i plemeniti liscari ireba da imaju prvenstveno biomeliorativnu uiogu.

Da bi se sto bolje iskoristio relativno mai prinosni potencijal ovih stanista $i$ osigurala stabilnost produkcije, $t j$. da bi se trajno povećao prinos $i$ poboljsao njegov kvalitet, potrebno je u procesu gazdovanja ovim sumama težiste staviti ra postepeno formi ranje mješovitih raznodobnih sastojina jele $i$ smrče sa nesto bukve $i$ plemenitih lišcara.

S obzirom na sastav suma ovog proizvodnog tipa 5 jedne, testanišne uslove $i$ ekološke osobine jele, smrč $i$ bukve, s druge strane,predvidjeni cilj bi se najefikasnije ostvario skupinasto-prebornim sistemom gazdovanja.

Pod uslovom da ce stabla jele $i$ smrče dostizati visine koje u prosjeku odgovaraji trecem, a stabla bukve ceturtom bonitetnom razredu, elementi numalnog sastava za sume ovoga proizvodnoga tipa bili bi, uz taksacionu granicu od :0 cm, sljedeci:

- vrsta drveca $i$ omjer smjese: jela 0,7 , smrča 0,2 , bukva 0,1 ,

- maksimalni stepen sklopa na kraju desetogodišnjeg turnusa: 0,70 ,

- maksimalni (završni) debijinski stepen do koga ce se uzgajati stabla: jele i smrče $70 \mathrm{~cm}$, bukve $60 \mathrm{~cm}$,

- srednji precnik stabala (u sredini turnusa): jele oko $25 \mathrm{~cm}$, smrce oko $24 \mathrm{~cm}$ i bukve oko $22 \mathrm{~cm}$.

Uz navedene uslove nomalna zaliha u sredini turnusa bi iznosila:

$\begin{array}{lcccc}\text { Vrsta drveta: } & \text { jela } & \text { smiča } & \text { bukva } & \begin{array}{c}\text { ukupno } \\ \mathrm{m}^{3} / \mathrm{ha}\end{array} \\ \text { krupnog drveta } & 210 & 60 & 30 & 300 \\ \text { Sveukuprid drvia masa } & 250 & 70 & 35 & 355\end{array}$


Tekući godišnji zapreminski prirast, odnosno prinos kojji bi se ostvario ovakvim normalnim sastavom bi iznosio:

$\begin{array}{lcccc}\text { Vrsta drveta: } & \text { jela } & \text { smrăa } & \text { bukva } & \begin{array}{r}\text { ukupno } \\ \mathrm{m} 3 / \mathrm{h} \text { a }\end{array} \\ \text { Krupnog drveta } & 5,6 & 2,8 & 0,4 & 8,8 \\ \text { Sveukupne drvne mase } & 6,5 & 3,2 & 0,5 & 10,2\end{array}$

PROLZVOINI TIP: VI-b-3,4

SUUMF JELE I SMRCEE NA DUBOKOM KALKOKAMBISOI.U I LUVISOUU NA KRECNJAKU I DOLOMI TU

Zbog slichih ekolosko-vegetacijsk in i razvojno-proicvodnih ka rakteristika suma jele i smrce na dubokon kalkokanbisolu i na luvisolu no krecnjacko-dotomitnim stijenana one su surstane uisti proizvodni tip.

Radi se, naime, o dva tipa zemljista koja i pored kvalitetnin razlika, u rezultanti pokazuju približno iste ekoloske karakteristike. ro

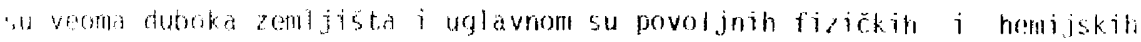
osobina, tako da je moguca primjena mehanizacije pri sumsko uzgojnim radovink. Najcescce se nalaze u kompleksu i dosta tesko in je na terenu tacro razdvojti. S abzirom na prinosni potencijal spadaju u bolja. Isti se tertilizacijom, narocito fosforom $i$ azotom, moźe znatno povecati us usloviha normal nog gazdovanja nisu podložna eroziji, ali su podloźna zakorovijavanju gramineama.

Sume ovoga proizvodnoga tipa, kao i ostale mješvite sume jelc i smrče i ciste smrčeve šume u Bosni, koje su obuhvacene ovin istrażivan.jima, najčšce se nalaze na visoravnima iznad 1000 metard nadmorske visine, na kojima se cesto javljaju kasni i rani nirazevi, te cesto veoma niske temperature $u$ toku zime, koje smrca bolje podnosi pa je ovdje jako zastupljena, u progresiji sumske vegetacije, kao $i$ jela, a udio bukve $i$ ostalih lišcara je znatno manji, do 10, maksimalno 15 procenata.Kvalitet bukovih stabala je veoma los. Ovom u dobroj mjeri doprinosi i negativan antropogeni uticaj (paša, sječa bukve radi ogrjeva ili dobijanja drvenog (u) jena).

Ukupna površina šuma ovoga proizvodnoga tipa iznosi oko 16120 liektard. U tome sume nu dubokom kalkokambisolu participiraju sa oko 8840 
ha ili 55 procenta, a sume na luvisolu sa oko 7280 hektara ili ts procenata

Sobzirom na osnovne geomorfoloste karakteristike ("ndthrsfu visinu, ekspoziciju i inktinaciju) ova dva osnovna tipa sum se tak...ji.

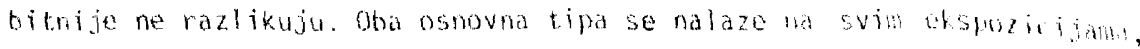

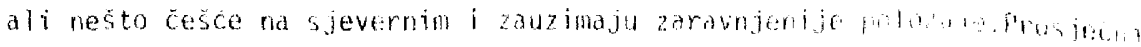

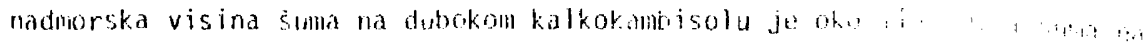

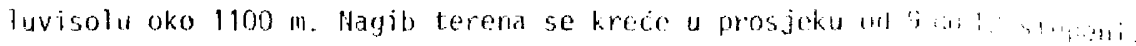

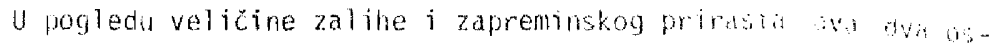

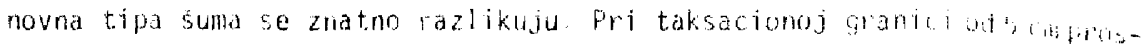

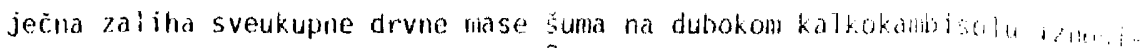

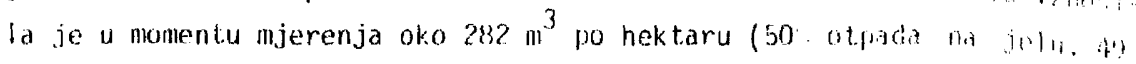

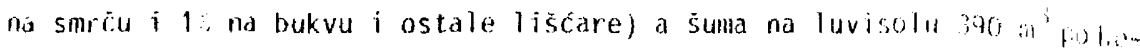
ktaru (57. otpada na jelu, 39:. na smrču, 2" na bijeli hor $i$ ? na butivi. i ostale lišcare). Tekuči godišnji zaprentinski prirast sulia ha dubotom kalkukambisolu iznosio je $7.33 \mathrm{~m}^{3}$ po hektaru, a suna na $\mid u v i c o l u$, $, 11,3$ po hektiru.

Konstatovane razlike u velicini zal ihe i zapreminshog firicita izmedju ova dva osnovna tipa šma posljedica su, u prvon redu. nijin. ve razlicite strukturne izgradjenosti (raspodjele stabala po dobljicki: stepenima) a ne razlicitog prinosnog potencijala ova dva tipa zeml jicia

Razlike u bonitetu staništa. koji je ocijenjen na bazi visici stabala jele i smrce, izmedju ova dva osnovna tipa suma suprakticro za. nemarljive, u prosjeku su manje od jedne polovine bonitetnon rarridu

Prosjecni bonitetni razred stanicta iznosio je za:

Vrsta drveti:

Na dubokom kalkokambisolut

Na luvisolu

\begin{tabular}{|c|c|c|}
\hline jelu & smirču & 1. bor \\
\hline$I I, 6$ & 111,2 & $11 ! .0$ \\
\hline, 3 & $I I], 0$ & iv, \\
\hline
\end{tabular}

Eoritet starista za bijeli hor u bukvu nije pourdano o:liedinli zhog nithovog malog wiesca

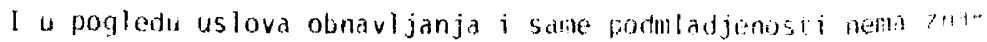
cajne razlike izhedju ova dva usnovna tipa suma stanje podmiatka atam voljava kako s obzirom na broj. tako i s obzirom ma kaljtet jiljata 
Kvalitet zaliha četinara, s obzirom na tehničku upotrebljivost njenih stabala, je zadovoljavajuci. Udio stabala prve $i$ druge tehničke kvalitetne klase u zalihi je veći od 80 procenata u oba osnovna tipa šuma. Kvalitet zalihe lišcara je veoma los.

\section{CILJ GAZDOVANJA}

I u ovom slučaju radi se o stanišnim uslovima u kojima se jelom i smrčm ostvaruju veliki i kvalitetni prinosi, dok je kvalitet bukovih stabala veoma loš. Radi toga, u sumama ovoga proizvodnoga tipa jela i smrča treba $i$ dalje da ostanu glavne vrste drveća sa kojima ce se gazdovati, dok bukva i plemeniti lišcari treba da imaju prvenstveno biomeliorativnu ulogu $i$ njihov udio u zalihi ne bi trebao da prelazi 20 procenata.

Prena tone, u procesu gazdovanja ovim sumama teżište treba staviti u prvom redu na trajno povecanje prinosa i poboljšanje njegovogkvaliteta. Pri tome treda postepeno formirati mješovite raznodobne sastojine jele $i$ smrče sa nešto bukve. Taj cilj se najefikasnije može ostvariti ako se u procesu gazdovanja ovin sumama primijeni skupinasto-prebormi sistem gazdovarija.

Uz pretpostavku da ce jelova stabla postizati visine koje u prosjeku odgovaraju drugom, smrčeva trecen $i$ bukova cetvrtom bonitetnom razredu, elementi normalnog sastava za ovaj proizvodni tip suma pri primjeni skupinasto-prebornog sistema gazdovanja bili bi pri taksacionoj granici od $10 \mathrm{~cm}$ sljedeci:

- vrsta drveća i mjer smjese: jele 0,6, smrče 0.2, bukve 0,2,

- maksimalni stepen sklopa na kraju desetogodišnjeg turnusa: 0.73 ,

- aavršni debljinski stepen: za jelu $75 \mathrm{~cm}$, smrču $70 \mathrm{~cm}$, bukvu $60 \mathrm{~cm}$,

- srednji precrijk stabala u sredini turnusa: jele oko $27 \mathrm{~cm}$, smrce oko $25 \mathrm{~cm}$ i bukve oko $22 \mathrm{~cm}$.

Pri ovakvim elementima normalna zal iha u sredini turnusabi iznosila: 
Vrsta drveta

jela

smrca

bukva

ukupno

Krupnog drveta

220

73

2.3

mistha

sveukupne drune mase

$262 \quad 87$

$87 \quad 87$

3

, ?

Tekuci zapreminski prirast, odnosno prinos, koji bi se usturi, ovakvim nomalnim sastavon bi iznosio:

Sursta drveta

\begin{tabular}{|c|c|c|c|}
\hline jela & smrica & bukvä & 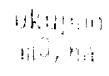 \\
\hline 6.4 & 1.9 & 1,1 & $\because ;$ \\
\hline 7,4 & 2,1 & 1,3 & 10. \\
\hline
\end{tabular}

Krupnog drveta

Sveukupne drvne trise

PROLZVODNI IIP: VI-b-6,7,8

SUHE JFLE I SMRCE NA DUBOKOM DISTRICNOM KAMBISOLU, LUVISUI:

PSEUDOCIEJU NA KISELIM SILIKATNIM STIJENAMA

Ovim proizvodnim tipom obuhvaćcond su tri osnovne tipa suma jele i smrče na kiselim silikatnim stijenama: na dubokom districrom kani isoli, luvisolu i pseudogleiu.

Razlozi za spajanje ovih osmovrih tipova u jedanproizvoini tip su njihove približno iste ekološko-vegetacijske i proizvodne karakteristike. Radi se, naime, o zamljištima koja su obrazovana na mekšim i rastresitim supstratima, tako da in je fizioloski aktivni profil veoma dubok, a uz to su im fizicka i hemijska svojstra dosta slicha, tako da su, kiko prinosni potencijal tako $i$ uslovi nastanka $i$ razvoja sastojina na ova t.ri tipa zemljišta $u$ datim klimatskim uslovima, približno isti. Zamljišta su duboka, slabo skeletna i male povrsinske kamenitosti. U uslovima normalnog gazdovanja nisu podložna eroziji, ali su podložna zakorovljavanju, narocito sa bujadi (eteridium aquilinum) i vrijeskon (Colithis bulqumis). Mogućnosti primjene mehanizacije u procesu gazdovanja šumana su vejua velike ra sva tri tipa zemljista.

S obzirom na pouršinu najviše je zastupljen prvi osnovni tip, (šume jele i smrče na dubokom distričnom kambisolu) sa oko 6170 hektara ili 53\%, zatin drugi (šume jele i smrče na luvisolu), sa oko 3640 hektara ili $32 \%$, a najmanje treci (šme jele i smrče na pseudogleju), sa oko 1740 hektara 111 15\%. Prema tome, ukupna povrśina šma ovoga proizvodnog 
tipa iznosi oko 11550 hektara.

sume ovoga proizvodnoga tipa se nalaze na svis ekspozicijama, (nesto cešcte na sjevernim) i zauzimaju uglavnom zaravnjene poloz̆aje. Razlike u nadmorskoj visini izmedju ova tri osnovra tipa šuma su takodje nezratre. Prosječna nadmorska visina suma jele $i$ smrče na distričnomkanbisolu je oko $1100 \mathrm{~m}$, na Tuvisolu oko $1090 \mathrm{~m}$, na pseudogleju oko $1070 \mathrm{~m}$.

Prosjeche velicine glavrih taksacionih elenenata (zalihe, zaprenifiskng primasta, honiteta stanista, zastrtosti tla krosnjama stabala, broj biljaka podmlatka) ova tri asnovna tipa suma bile su sljedece:

\begin{tabular}{|c|c|c|c|c|c|c|c|}
\hline $0 \mathrm{st}$ & novni tip sumes & $\begin{array}{l}\text { Vrsta } \\
\text { drveta }\end{array}$ & $\begin{array}{l}\text { Bonite- } \\
\text { tni } \\
\text { razred }\end{array}$ & $\begin{array}{l}2 a \text { l iha } \\
\left(m^{3} / h a\right)\end{array}$ & $\begin{array}{c}\text { Godišnji } \\
\text { zaprem. } \\
\text { pri- } \\
\text { rast }\end{array}$ & $\begin{array}{l}\text { Zastr- } \\
\text { tost tla } \\
\text { krošnja- } \\
\text { ma }\end{array}$ & $\begin{array}{c}\text { Broj bi- } \\
\text { 1jaka pod- } \\
\text { mlatka } \\
\text { (kom/ha) }\end{array}$ \\
\hline \multirow[t]{4}{*}{1} & \multirow{4}{*}{$\begin{array}{l}\text { sume jele i } \\
\text { shirce na du- } \\
\text { bokom dist- } \\
\text { richom kalm- } \\
\text { bisolu }\end{array}$} & Jela & 11,7 & 117,9 & 4,18 & & 6.769 \\
\hline & & Smrča & $I \amalg I, 0$ & 96,9 & 3,69 & & 3.307 \\
\hline & & Liscari & 11,0 & 6,1 & 0,11 & & - \\
\hline & & Sve & & 220,9 & 7,98 & 0,75 & 10.076 \\
\hline \multirow[t]{4}{*}{11} & \multirow{4}{*}{$\begin{array}{l}\text { Sune jele } i \\
\text { smrce na lu- } \\
\text { visolu na } \\
\text { kis. silik. } \\
\text { sti.jenana }\end{array}$} & Jela & $I I I, 0$ & 221,6 & 5,50 & & 7.174 \\
\hline & & Smrča & III,O & $13 \uparrow, 0$ & 2,64 & & 1.213 \\
\hline & & Liscari & II, 0 & 3,5 & 0,02 & & - \\
\hline & & Sve & & 356,1 & 8,16 & 0,62 & 8.392 \\
\hline \multirow[t]{4}{*}{111} & \multirow{4}{*}{$\begin{array}{l}\text { sume jele i } \\
\text { smree na } \\
\text { psetilogl na } \\
\text { kis. silikat. } \\
\text { stijerama }\end{array}$} & Jela & 111,3 & 186,8 & $2,7 ?$ & & 4.636 \\
\hline & & Snréa & II $I, 4$ & 107,4 & 3,29 & & 4.364 \\
\hline & & iscari & IV, 0 & 4.1 & 0,29 & & $\therefore$ \\
\hline & & Sve & & 218,3 & 6,30 & 0.58 & 9.000 \\
\hline
\end{tabular}

Velicina zalihe, zapreminskog prirasta i zastrtost tla krošnjamo uturdieni su na bazi taksacionog "praga" od $5 \mathrm{~cm}$. Zapremina i zapreminski prirast odnose se na sveukupnu drvnu masu. Bonitet staništa ocijenjen jo na bazi visina stabala.

Konstatovane razlike u velicini zalihe i tekuceg godišnjeg zapreminskog frirasta izmedju ova tri osnovna tipa šma nisu odraz razlic̈ilug prinosng potencijala ova tri tipa zemljista nego su one (razlike) u prvom redu posijedica različice iskoriscenosti i strukturne izgradje- 
nosti (horizontalne i vertikalne) ova tri nsnovna tipa suma

Rezalike u bonitetu stanista izmedju šma jele i smire na dum.

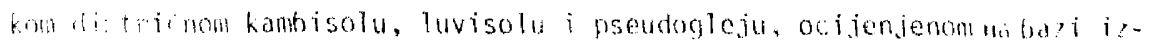
mjerenith visina jelovih i smréevih stabala, su prakticno zancenarljive. prosjeku ne prelaze /1/2 visinskog bonitetnog razreda. Istina ove ruzlikn su neśto vece kada se radi o jel i na dubukom kichlom smedirm zemi jictu i pseadorleju. Medjutim, ni one (razlike) nisu signifikantur.

Poduladjenost suma ovoga projzvornoga tipa je zadrvelinvajua... kako, s obzirom na vrste drveca i broj biljaka, tako $i s$ olzirom na kvalitet. Kvalitet zalihe s obziron na telinicku upotrebljivost njenit sta bala je ujednaćen i dosta dobar u sva tri osnovna tipa. Udioprve i cir. ge tehnicke kvalitetne klase u zalihi prvog osnovnog tipa (na dubokom districnom kanbisolu) iznosio je 82,7\%, drugog (na luvisolu) 81,0\%, i treceg (na pseudogleju) $76,5 \%$.

\section{CIL.J GA.ZDOVANJA}

Sune ovoga proizvodnoga lipa spadaju takodje u najholje nase sume, kako s obzirom na velicinu prinosa tako i s obzirom na njegov kvoliter. Jela $i$ smrca ovdje treba $i$ dalje da budu glavne vrste arveca sa kojima ce se gazdovati. Bukva i plemeniti liscari treha da imaju prvenstveno biomelionativnu ulogu i njihovo ucesce u zalihi ne bi trebalo da prelazi 20 procenata.

I u sumama ovoga proizvodnoga tipa, zbog dosadašnjeg nacinata. zolovinja, coste su partije rijetkin i loš in stabala, nepodmadjene plesine $i$ slicho. zbog cega je njihova efektivna produktivnost ispod prinosnog potencijala staništa. Stoga u procesu gazdovanja sumana ovoga proizvodnog tipa težcte treba staviti u prvom redu. na saniranju postojecéa loseg stanja. Sobziroli ne to. kao i s obzirom ma bioekoloske osoline jele. smrče, (bukve) preporučuje se kao najracionalniji skupinasto-preborni sistem gazdovanja sa sljedecim elementima normalnog stania (pri taksacionoj granici od $10 \mathrm{~cm}$ :

- vrsta drveca i omjer smjese: jela 0.6 . smrcia 0,2 bukva iple. meniti lišcari: 0.2 .

- bonitetni razred stanista ocijenjen na bazi visina stabala: drugi za jelu i smrču. a treci za bukvu i plemenite licadra. 
- maksimalni stepen sklopa na kraju desetogodišnjeg turnusa: 0,75 .

- srednji prećnik stabala 1 sredini turnusa: za jeluokn? $\mathrm{cm}$. smríu oko $26 \mathrm{~cm}$, a bukvu i ostale liscare okn $23 \mathrm{m.}$

- zavrŏni debljinski stepen: $7 a$ jelu $i$ smriu 75 cal, a bukvu i plemerite lisare to $1 \%$

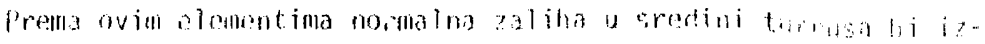

\begin{tabular}{|c|c|c|c|c|}
\hline Vista drvota: & jela & smrča & bukva & $\begin{array}{l}\text { ukupno } \\
m^{3} / h \text { o }\end{array}$ \\
\hline ki uplogig diveta & 694 & $i n$ & 78 & $3: 19$ \\
\hline Swlikuphe drvate anse & 200 & 93 & 43 & $4 i, i$ \\
\hline
\end{tabular}

Tokuci zapeminski prirast odnosno prinos koji bi se ostvarie watkvin nowalnim sistavou iznosto bi:

Vrsta drvela:

kimpnoy drvet.i

sviukupme arvne mase

$\begin{array}{cccc}\text { jela } & \text { smrča } & \text { bukvà } & \begin{array}{c}\text { ukupin } \\ \text { 月 } 3 / \text { ha }\end{array} \\ 6,4 & 2,0 & 1,3 & 9,7 \\ 7,4 & 2,4 & 1,5 & 11,3\end{array}$

Cilj gazdovanja predvidjen za ovaj tip šume može se primijeniti na sljedoce osnovne tipove šuma: sume jele $i$ smrče na plitkom distričnom kambisolu (VI-b-b): šume jele i smrče na podzolu i brunipodzolu (VI-b-9)*.

\author{
C. $\zeta$ u $\mathrm{e} s m r \dot{c}$ e \\ PROIZVODNI IIP: VI-C-1,3
}

SIJME SMREE NA KALKOMELANOSOLU I PLITKOM KALKOKAMBISOLU

Ovaj proizvodni tip formiran je takodje iz dva osnovna tipa cistih smrčevih šuna na krećnjacko-dolomitnim stijenama: na kalkomelanosola i plitkon kalkokambisolı.

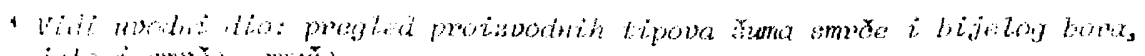
ivle $t$ impres, amrote? 
Po površini prvi osnouni tip (šume smirce na kalkomelanosolu) zastupljen je sa oko 2530 hektara, odnosno 55 procenata, a drugi (sume snrče na plitkom kalkokambisolu) sa oko 2060 hektara odnosno 45 procenata. Ukupna površina suma ovoga proizvodnoga tipa iznosi oko 4590 hektara.

Prosječna nadmorska vișina suma smrče na kalkomelanosolu jeoko $1220 \mathrm{~m}$, a na plitkon kalkokambisolu oko $1120 \mathrm{~m}$. Prosječni nagib tercna krece se od 10 do 20 stepeni. Oba osnowna tipa nalaze se na svim ciajorcijama. Sume smrče na kalkomelanosolu se nešto češce javljaju na zapadmim a šume smrče na plitkom kalkokambisolu na sjevernim ekspozicijama.

Prosječni bonitetni razred staništa, ocijenjen na bazi visina smirčevih stabala, nešto je bolji u šumama na kalkomelanosolu $(I 11,6)$ negu u šumama na plitkom kalkokambisolu (IV,2) i ako bi, s obzirom na osobine zemljišta, trebalo da bude obratno.

Slican odnos ispoljio se i u velicini zalihe $i$ tekuceg zapreminskog prirasta. Prosjecna zaliha, iskazana sveukupnom drvnom masom na bazi taksacionon praga od $5 \mathrm{~cm}$, iznosila je u sumama na kalkomelanosolu oko $228 \mathrm{~m}^{3}$ po hektaru, a u šumama na plitkon kalkokambisolu oko $166 \mathrm{~m}^{3}$ po hektaru. Tekuci godišnji zapreminski prirast šuma na kalkomelanosolu iznosio je oko $5,2 \mathrm{nl}^{3}$ po nektaru, a suma na plitkon kalkokanbisolu oko 4.0 $\mathrm{m}^{3}$ po hektaru.

kvalitet zalihe, s obzirom na tehnicku upotrebljivost njenih stahala je prilicno loš u oba osnovna tipa. Naime, učesćce prve $i$ druge tehnicke kvalitetne klase u ukupnoj zalihi ne prelazi 60 procendta ni kod jednog osnovnog tipa ovih suma.

Prirodno obnavijanje suma ovoga proizvodnoga tipa je takodie veoma slabo.

\section{CILJ GAZDOVANJA}

II ovom sluçaju radi se, kako je vec istaknuto, o zemijištima koja s obzirom na prinosni potencijal spadaju u lošija i specificnim mikroklimatskim uslovima u kojina smrta izgradjuje sume trajnih stadijavegetacije. Prema tome $i$ u sumank ovoga proizvodnoga tipa smrca $i$ dalje mora oj ati hao jedina vrsta drveca sa kojom te se gazdovati. 
U cilju maksimalnog korišcenja prinosnog potencijala stanista $i$ povecanja stabilnosti produkcije preporučje se forniranje raznodobnih sastojina grupimične strukture. S obzirom na zatečeni sastav sulia ovoga proizvodroga tipa i date staniše uslove predvidjeni cilj bi se najefikasnije ostvario ako bi se u procesu gazdovanja ovim sumama primijenio skupinasto-preborni sistem gazdovanja.

Podaci ukazuju da stabla smrce u ovom proizvodnam tipu štilla wostizu visine koje u prosjeku odgovaraju cetvrom bonitetrom razredu. Uz navedeni bonitet, prosjechi stepen sklopa na kraju desetogodisnjeg turnusa 0,63 (taksaciona granica $10 \mathrm{~cm}$ ), srednji prečnjk smreevih statala u sredini turnusa 23 an i zavrs̄ni debljinski stepen do koga ce se uzgajati stabla $60 \mathrm{~cm}$, nomalna zaliha u sredini turnusa bi iznosila oko $220 \mathrm{~m}^{3}$ po hektaru krupnog drveta, odnosno oko $260 \mathrm{~m}^{3}$ po hektaru sveukupne drune wasis.

Tekuci godisnji zapreminski prirast, odnosno prinos, kojibi se ostrario ovakvim normalnim sastavom bi iznosio oko $6,0 \mathrm{~m}^{3}$ pohektaru k.rupnog diveta. odnosno oko $7.0 \mathrm{~m}^{3}$ po hektaru sveukupne drvne mase.

Cilj gazdovania predvidjen za ovajproizvodni tip şume maže se primijeniti ra sljedeci osnovni tip sume: sume surce na dolonitnoj rendzini $(V I-r-2)^{*}$.

PROIZVODNI TIP: VI $-\mathrm{C}-4,5$

SUME SMRCF: NA DUBOKOM KALKOKAMBISOLU I LUVISOLII

NA KRECNJAKA T DOLOMITU

U ovaj proizvodni tip svistana su dva osnovna tipa cistii suma smice na krec̆njackko-dolomitnim stijenama: na dubokom kalkokanbisolu i juvisolu.

Ukupna površina šuma ovoga proizvodnoga tipa je oko 7120 hektara. 1 tome sune simrce na dubokom kalkokambisolu participiraju sa utu 2850 hektara ili 40 procenda, a na luvisolu sa oko 4270 hektara ili 60 procemita.

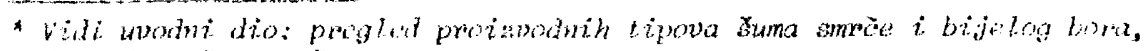

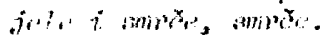


Zastupljene su na manjim površinama unutar šuma jele i smrçe (bukve) gdje zazimaju izrazita mrazista. Javljaju se na svim ekspozici. jama podjednako. Prosječna nadmorska visina suma smrče na dubokom kalkokambisolu iznosi oko $1200 \mathrm{~m}$, a na luvisolu oko $1270 \mathrm{~m}$. Nagib terena kreco se 4 prosjeku od 6 do 13 stepeni.

Prosječne veličine glavnih taksacionih elemenata ova dva usmuvna tipa suma u doba snimanja bile su sliedece:

Osnovni tip sume

\section{Vrsta Borit. Lalina arveta razrod (n3/ha) (m3/na) Sklop}

Broj bi i..

liaka

podial altín

po his

\begin{tabular}{|c|c|c|c|c|c|c|}
\hline \multirow{3}{*}{$\begin{array}{l}\text { Sume smrce na dubo- } \\
\text { kon kalkokambisolu }\end{array}$} & smrice & {$[1], 1$} & 182.5 & 6,51 & & $4.9 \%$ \\
\hline & ostale & III, 5 & $\therefore 4$ & 0,09 & & 222 \\
\hline & sve & & 184,9 & 6,60 & 0.53 & $5.14 \%$ \\
\hline \multirow{3}{*}{$\begin{array}{l}\text { Sume smrčena luviso- } \\
\text { lu na krecnjacima }\end{array}$} & smrča & 11,9 & 279,0 & $4,2 ?$ & & 5.389 \\
\hline & ostale & - & .. & - & & \\
\hline & sve & & 279,0 & 4.22 & 0.14 & 5.389 \\
\hline
\end{tabular}

Velicina zalihe, zapreminskog prirasta i stepena sklopa utvr djeni su na bazi taksacionog praga od $5 \mathrm{~cm}$. Zaprenina i zapreminski prirast odnose se na sveukupnu drvnu masu. Bonitetni razred stanista ocijenjen je na bazi visina stabala.

Navedeni podaci ukazuju, izmedju ostalog, da izmedju osnovaih tipova s̆uma koji su obuhvaceni ovim proizvodnim tipom nisu konstatovane značajne razlike u bonitetu staništa ocijenjenom, na bazi visina stahala smrče. Medjutim, uprkos tome, izmedju ova dva osnovna tipa suma konstatovane su znaçajne razlike $u$ veliçini zalihe i zapreminskog prirasta. Zaliha suma prvog osnovnog tipa (na dubokom kalkokambisolu) bila je u prosjeku flanja za cca $100 \mathrm{~m}^{3}$ po hektaru od zalihe šuma drugog osnovnog tipa (na luvisolu). Sto se tice zapreminskog prirasta situacija je obratna.lapreminski prirast suma prvog osnovnog tipa (na dubokom kalkokambisolu) bio je u prosjeku veci za $2,4 \mathrm{~m}^{3}$ po hektaru od zapreninskog prirasta suma drugog osnovnog tipa (na luvisolu). Osnovni uzrok ovome je raspodjela statiala po debljinskim stepenima. Naime, debljinska struktura zaline suma na dubokom kalkokambisolu pomjerena je jako u tanje debljinske kla- 
se $u$ odnosu ra debijinsku strukturu zal ihe šuma na luvisolu. Tako, npr., u sumama na dubokom kalkokambisolu od ukupne zapremine otpada na zapreminu stabala debljinske klase od 50 do $80 \mathrm{~cm}$ samo 6,8 procenata, a u sumama na luvisolu čak 46,2 procenta.

Mali zapreminski prirasti posljedica su nedovoljne iskorišcenosti proizvodnog prostora, $t j$. dosta niskih stepena sklopa u oba osnovna tipa šma.

Kvalitet smrčevih stabala s obzirom na njihovu tehnicku upotrebljivost $u$ prosjeku zadovoljava u oba osnovna tipa šma, ali je ispod prosjeka kvaliteta smrcevih stabala u drugim osnovnim tipovima obuhvacenim ovim istraživanjima. Smrčeva stabla u šumama ovoga proizvodnoga tipa su granatija $i$ više mišorepasta. Uzrok ovome je najvjerovatnije nizak stepen sklopa.

Podmladjenost šuma ovoga proizvodnog tipa zadovoljava kako s obzirom na broj tako i s obxirom na kvalitet biljaka.

\section{CIL.J GAZDOVANJA}

Kako je vec ranije istaknuto u ovom slucaju radi se o zemljistima koja imaju visok prinosni potencijal i specifičnim mikroklimatskin uslovima koji uslovijavaju da se u šumama ovoga proizvodnoga tipa osim snace druge vrste drveca prakticho ne javijaju. Razumljivo je onda da u datim stanišim uslovima smrča $i$ dalje mora ostati kao jedina vrsta sa kojom ce se gazdovati.

Sume ovoga proizvodnoga tipa daju u prosjeku relativio malen prirast u odnosu na prinosni potencijal staništa. Razlog je u prvom redu nepotpuno korišcenje proizvodnog prostora, nizak stepen sklopa i nepovo* Ijna dobljinska struktura zalihe. Zbog toga, u procesu gazdovanja ovim sumana, težište treba staviti, u prvom redu, na popravijanje postojećg lošg stanja u pogledu strukture zal ihe $i$ boljem korišcenju prinosnog potencijala staništa, tj. na trajnom povećanju prinosa $i$ poboljšanju njegovog kvaliteta.

S nbzirom na zatečeno stanje u strukturnoj izgradjenosti suma ovoga proizvodnoga tipa. uslove stanista i bioekološke osobine smrže. predvidjoni cilj bi se najefikasnije rea? izovao primjenom skupinasto prebornog sistema gazdovanja. Skupinama bi se prvenstveno zahvatale partije 
starih i rijetkih stabala, partije losih stabala, nepodnladjene plesine, ukratko, po:ršine na kojina se postojecim inventarom ne koristi proizvodni prostor na zadovoljavajući naćin. Skupine bi se vjestački obnavljale odraslim školovanim sadnicama smrče. Na taj način bi se unajkraćenl mogucem vremenu saniralo postojece loše stanje i maksimalno povecao prirast uz istovremeno ostvarivanje najpovoljnijih ekonomskih efekata $u$ procesu gazdovanja.

Podaci ukazuju da stabla smice u ovom proizvodnom tipu suma pu... stižu visine koje u prosjeku odgovaraju trecem bonitetnom razredu. Uz navedeni bonitet, prosječni stepen sklopa na kraju desetogodišnjeg turnusa 0,66 (taksaciona granica od $10 \mathrm{~cm}$ ), srednji prečnik smrčevih stabala sredini turnusa 24 cm i maksimalni (završni) debljinski stepen 70 cril, normaina zaliha u sredini turnusa bi iznosila oko $320 \mathrm{ml}^{3}$ po hektaru brupnog drveta odnosno oko $380 \mathrm{~m}^{3}$ po hektaru sveukupne drvne mase. ovakvin normalnim sastavom mogao hi se astvariti tekuci godisnji zapreminski mri. rast, tj. prinos od $7,3 \mathrm{~m}^{3}$ po hektaru krupnog drveta, odnosno oko $8,5 \mathrm{~m}^{3}$ po hektaru sveukupne drune mase.

Ako bi se ove sume tretirale kao jednodobne sastojine onda bi se u ovakvim sastojinama prema prinosnim tablicama (1975) uz produkcioni period od 120 godina $i$ umjerene prorede mogao ostvariti prosječni godisnji zapreminski prirast uključivši i proredni materijal, tj. prinos od $7.6 \mathrm{~m}^{3}$ po hektaru krupnog drveta, odnosno oko $8,8 \mathrm{~m}^{3}$ po hektaru sveukupne orvne maso.

PROIZVODNI TIP: VI-c-7,8,9

SUME SMRCE NA DUBOKOM DISTRICNOM KAMBISOLU, LUVISOLU I PSEUDOGLEJA NA KISELIM SILIKATNIM STIJENAMA

Zbog specifičnih ekološko-proizvodnih i razvojnih karakteristika క̌uma smrče na dubokom distričnom kambisolu na kiselim silikatnim stijenama one su izdvojene u poseban proizvodni tip. To su, moze se slobodno reçi, najbolje šume smrče u Bosni, koje istovremeno imaju i najvecu efektivnu produktivnost.

Duboki distrični kambisol obuhvata više varijanti istoga tipa zemljišta, u zavisnosti od prirode matičnog supstrata, koja su veoma duboka, slabo skeletna $i$ male površinske kamenitosti, tako da je mogućnost 
mehanizovane obrade zemljista $i$ primjene mehanizacije u procesu gazdovanja sumama veona velika. Zemljišta su povoljno vlażena $i$ imaju visok prinosni potencijal koji se mjerama fertilizacije može znatno poboljšati.

Ukupna površina కuma ovoga proizvodnoga tipa je oko 3640 hektara. Prosjecria nadmorska visina im je oko $1060 \mathrm{~m}$, a prosječna inklinacija terena oko 15 stepeni. Nalaze se na svim ekspozicijama, nešto rjedje na južnim.

Bonitetni razred staništa ocijenjen na bazi visina smrčevih stabala krece se od II, 3 do III,3 li prosjeku je II,9.

Pri prosjećnom stepenu sklopa od $0,54 i$ pri taksacionom pragu od $5 \mathrm{~cm}$, prosjecna zaliha sveukupne drune mase suma ovoga proizvodnoga tipa iznosila je u doba mjerenja oko $237 \mathrm{~m}^{3}$ po hektaru. Is tovremeno tekuti godisnnji zapreminski prirast ove zal ihe iznosio je $8,07 \mathrm{~m}^{3}$ po hektaru. (ovo je najveci prirast koji je utvrdjen u svim izdyojenim osnovnim tipovima čistih smrčevih šuma $u$ BiH).

Kvalitet zalihe u pogledu tehničke upotrebljivosti njenih stabala u protpunosti zadovoljava. Veliki udio prve tehničke kvalitetne klase (74\%) ukazuje da se u sumama ovoga proizvodnoga tipa racionalnim gazdovanjen moze ostvariti prinos izuzetnog kvaliteta.

Stanje podmlatka ne zadovoljava iako je podmladak po broju biljaka dovoljno zastupljen. Naime, od ukupnog broja biljaka podmlatka 32 posto je zastarćceno, a 42 posto ośteceno.

\section{CILJ GAZDOVANJA}

I u ovom kao i u prethodnom proizvodnom tipu čistih šuma simrče zhog specifičnih stanišnih - nikroklimatskin uslova koji, osimsmrče, ne dozvoljavaju pojavu drugih vrsta drveća, smrća j dalje mora ostati ka jedina vrsta drveca sa kojom ce se qazdovati.

Sume ovoga proizvodnoga tipa i pored dosta niskog stepena sklopa $(0,54)$ imoju relativno visok prirast $\left(8,07 \mathrm{~m}^{3} / \mathrm{ha}\right)$, koji je odraz pored povoljnin zemljistnin uslova $i$ dosta povoljne debljinske strukture postojece zalihe. zbog toga u procesu gazdovanja ovim sumama teziste treba staviti u prvom redu na ocuvanju njihove efektivne produktivnosti, a istovremeno i na trajnom povećanju prinosa i poboljsanju rijegovog kvalite- 
ta. To se može najefikasnije postiçi ako se u ovim Šumama,kão i u šumama prethodnog proizvodnog tipa, primijeni skupinasto-preborni sistem gazdovanja. Prilikom izbora lokacija za skupine prvenstveno treba uvazavati princip kontinuiteta produkcije, కto praktično znači da skupine treba formirati tamo gdje se postojecim inventarom na zadovoljavajući nacin ne koristi proizvodni prostor. Skupine bi se pošumijavale odrastim školovanim sadnicama smrce, a koristio bi se i postojeci prirodni podmladak, jasno ukoliko je dobrog kvaliteta. Na taj način bi se formirale više ili manje raznodobne smrčeve sastojine grupimične strukture.

Podaci ukazuju da i u ovom proizvodnom tipu šuma stabla smrče postižu visine koje u prosjeku odgovaraju trećem bonitetnom razredu. ReaIna je pretpostavka da se dobrim gazdovanjem i fertilizacijommogu postici visine stabala smrče, koje bi u prosjeku odgovarale drugom bonitetnom razredu. Uz navedeni bonitet, prosječni stepen sklopa na kraju desetogodišnjeg turnusa 0,70 (taksaciona granica $10 \mathrm{~cm}$ ), srednji prečnik smrčevih stabala u sredini turnusa oko $26 \mathrm{~cm}$ i završni debljinski stepen $75 \mathrm{~cm}$, normalna zaliha u sredini turnusa bi iznosila oko $375 \mathrm{~m}^{3}$ po rektaru krupnog drveta, odnosno oko $440 \mathrm{~m}^{3}$ po bektaru sveukupne drvne mase.

Pri ovakvon normalnom sastavu mogao bi se ostvariti tekuci godisnji zapreminski prirast (toliki bi bio i prinos po količini) od oko $9,0 \mathrm{II}^{3}$ po hektaru krupnog drveta, odnosno oko $10,4 \mathrm{~m}^{3}$ po hektaru sveukuphe drunte mase.

Ako bi se sume ovoga proizvodnog tipa tretirale kao jednodobne sastojine onda bi se u ovakvim sastojinama prema prinosnim tablicama (1975) uz produkcioni period od 120 godina $i$ umjerene prorede mogao ostvariti prosječni godišnji zapreminski prirast uključivši i proredni mate;ijal od $9,4 \mathrm{~m}^{3}$ po hektaru krupnog drveta, odnosno oko $11,1 \mathrm{~m}^{3}$ po hektaru sveukuprie drvne mase.

cilj gazdovanja predvidjen za ovaj tip sume može se primijuni ti na sljedece osnovne tipove suma: sume smrce na plitkom districnomkambisolu (VI+C-6); sume smrče na podzolu i brunipodzolu (VI-C-10)*.

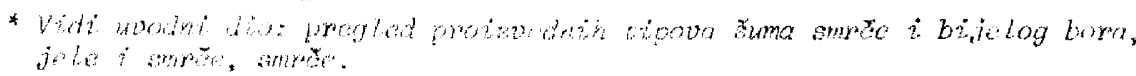




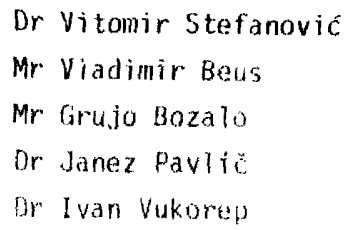

\section{MISCHWALDTYPEN DER FICHTE UNG FÖHRE, DER TANNE UND FICHTE UND FICHTENWÄLDER IN BOSNIEN}

\section{ZUSAMMENFASSLNG}

Eine typologische Klassifizierung dieser Wälder ist die Fort.setzung der Arbeiten an einer ökologisch - produktiven klassifizierung der Wälder in Bosnien. Sie stellt auch den Abschluss der typologiscta Klassifizierung von Hoctwaldtypen in Bosnien dar, die 1971 begann und in einer der ersten Arbeiten dieser Art in Jugoslawien $(c$ i $r$ i $\hat{c}, S t e-$ fa novic, Drinic, 1971) wissenschaftlich behandelt wurde.

Die angewandte klassifizierung umfasste die phytozenologischen, pedologischen und taxationen Charakteristiken in ihrenkorrelationen, und sie ist: zweiphasig. In der ersten Phase sind die Einheiten im Sinne von $s$ c $n l$ e $n k$ e $r$ mit annäherndghoichenökologisch - vegetativen Merkmalen oder die G $r$ u $n$ d $w$ a 1 d $t$ y p e $n$ ausdifferenziert. In der zweiten Phase wird auf Grund eines Uberblicks und taxationer Angabeneine definition der produktiven $w$ a $1 \mathrm{~d}$ t $y \mathrm{p}$ e $n$ und auf Grund von Kriterien hinsichtich der potentialen Standorte und der Bonität bzw. der produktiven Möglichkeiten auch eine Definition der Ziele einer Waldbewirtschaftung gegehen. Besonders werden dabei die Gefahren, denen der bestiminte Waldtyp ausgesetzt ist, beachtet: Erosion. Verunkrautung, Feuerschäden, Zerstörung durch Wind, Rohhumusbildung usw.

Bei der typologischen Klassifizierung dieser Nadelwälder Bosniens wurden folgende Grundwaldtypen innerhalb der Waldkategorien bearheitet: 
a) Fichten-und Föhrenwä lder

1. Fichten- und Föhrenwälder auf Rendzina aus Kalkstein

2.

Reridzina aus Dolomit.

3.

flachgründiger Braunerde

4.

tiefgründiger Braunerde

5.

Parabraunerde auf Kalkslein

6.

saurer Braunerde

7.

Parabraunerde und Pseudogley

b) I a nnen-undFichtenwälder

1. Tannen- und Fichtenwälder auf Rendzina aus Kalkstein

2 .

flachgrindiger Braunerde

3.

tiefgründiger Braunerde

4 .

Parabraunerde aud Kalkstein

5.

saurer Braunerde

6.

parabraunerde auf silikatgestein

7.

Pseudogley

c) F i chtenwä 1 der

1. Fichtenwälder auf

2.

3.

4.

5.

11
Rendzina aus Kalkstein

flachgründiger Braunerde

tiefgrundiger Braunerde

Parabraunerde aus Kalkstein und Dolomit

saurer Braunerde

a) Fichten- und Föhrenwäl der

$V_{1}-a-1,3$

1. Fichten- und Föhrenwälder auf Rendzina aus Kalkstein und flachgründiger Braunerde. 
$V l-a-?$

2. Fichten und Föhrenwälder auf Rendzina aus Dolomit.

VT $-a-4,5$

3. Fichten- und Föhrenwälder auf tiefaründiger Braunerde und Parabraurerde auf Kalkstein und Dolomit.

VI-A-7

4. Fichten- und Föhrerwälder auf saurer Braunerda.

b) Ta nnen-undfichtenwälder

$1 / 1-i,-1$,

1. Tamen- und fichtenwälder auf Rendzina aus kalkstein und flachroüridiger Bramerde.

$y j-b-3,7$

2. Tannen- und Fichtenwälder auf tiefgründiger Bratuerde und Parabraumturde und Dolomit sowie kalkstein.

$V[-6-6,7,8$

3. Tannen und fichteriwalder auf saurer Braunerde, auf Parabraunerde und Pseudogley auf saurem silikatgestein.

c) Fichtenwäl der

VJ $-\mathrm{c}-1,3$

1. Fichtenwälder auf Pendzina aus Kalkstein undflachgrindiger braunerde.

$V I \sim C-4,5$

2. Fichtenwälder auf tiefgrïndiger Braunerde und auf Parabraunerde auf Kalkstein und Dolomit.

$\forall-C-7,8,9$

3. Fichtenwälder auf saurer Braunerde, Parabraunerde und Pseudogley auf saurem silikatgestein. 


\section{LITERATURA}

Beus, V. (1980): Zajednica bukavo jelove sume na peridotitu $i$ serpentinitu Bosne, Radovi Sumarskog fakulteta i Instituta za šmarstvo u Sarajevu, god. XXIV (1979), Knjg. 24., Sv. 6., Sarajevo

cirić, M. (1966): Zamljišta planinskog područja Igman-Bjelašnica. Sum.fak. i Inst. za šum. Sarajevo, Radovi, knj. 10, sv. 1

Ciric, M., Stefanovic, V., Drinic, P. (1971): Tipovi bukovih šuma i mjeŠovitih suma bukve, jele i smrče u Bosni i Hercegovini, Sumarski fakultet $i$ Institut za sumarstvo, Pos. izdanje br. 8, Sarajevo

Fukarek, P. (1962): Inverzija vegetacije na planinskom masivu Igman-Bjelašnica, Narodni šumar, sv. 1-2, Sarajevo

Fukarek, P. (1970): Areali rasprostranjenosti bukve, jele i smrče na području Bosne $i$ Hercegovine, ANUBiH, Radovi - XXXIX, knj.11, Sarajevo

Matic, V. (1963): Osnovi i metod uturdjivanja normalnog sastava za preborne sastojine jele, smrce, bukve i hrasta na području Bosne. Radovi sumarskog fakulteta $i$ Instituta za šumarstvo idrvnu industriju u Sarajevu. God. VIIl, br. 8

Matic, V., Drinic, P., Stefanovic, V., Ciric, M. et al. (1971): Stanje šuma u SR BiH, prema inventuri šuma na velikim površinama $u$ 1964-1968. godini. Sumarski fakultet i Institut za sumarstvo u Sarajevu. Posebna izdanja: br. 7

Obradovic, S., Sentic, M. (1959): Osnovi statističke analize.Univerzitet $u$ Beogradu

Stefanovic, V. (1958): Areal prirodnog rasprostranjenja bijelog bora ( $i-$ mus siluestrisl u Bosni i Hercegovini, Radovi Polj.sum, fakulteta, Radovi br. 2, Sarajevo 
Stefanovit, V. (1960): Tipovi šuma bijelog bora (Pinus silvestris L.) na području krečnjaka istočne Bosne, Naučno društvo NR BiH, knj.4, Sarajevo

Stefanovic, V. (1969): Borove sume na dolomitu zapadne Bosne BugojanskoKupreškog područja, sum. list, sv. 1-2, Zagreb

Stefanovic, V. (1964): Sumska vegetacija na verfenskim pješčarima i glincima istocne $i$ jugoistočne Bosne. Radovi Sumarskog fakulteta $i$ Instituta za Sumarstvo i drvnu industriju, god. IX, Knj.9, Sv. 3, Sarajevo

Stefanovic, V. (1970): Fitocenoza bijelog bora i smrče sabrdskim lužnjakom kod Knežine na Romaniji (Ass. Piceo-Pinetum quercetosum roboria, Stef.). Radovi ANUBiH, Knj. II, Sarajevo

Stefanovic, V. (1970): Die Fichte und Fichtenwälder in Bosnien und Herzegowina in der Vegetationsverhältnissen der Dinariden. Ekologija, Vol. 5, No 1, Beograd

Stefanovic, V., Beus, V., Manuševa, L., Pavlič, J., Petrovic, M., Vukorep, I. (1977): Tipovi šuma hrasta kitnjaka u BiH; Tipovi క̌uma crnog $i$ bijelog bora u BiH. Radovi sumarskog fakulteta $i$ Instituta za šumarstvo u Sarajevu. God. $X X, k n j, 20,5 v, 1-2$

Škoric, A. (1977): Tipovi našin tala, Liber, Zagreb 


\section{SUMARSKI FAKULTET I INSTITUT ZA SUMARSTVO \\ U SARAJEVU}

\section{Posebna izdanja*}

1. MATIC V., VUKMIROVIC V., Tablice taksacionih elemenata visokih suDRINIC P., i STOJANDVIC ma jele, smrče, bukve, bijalog bora, cr0. : nog bora i hrasta kitnjaka na podrućjuBosne, Sarajevo, 1963.

2. DJIKIC S., KOLAKOVIC R.: Osnovi za proizvodno ekološku klasifikaciju zapustenih i degradiranih panjača u Bosni i Hercegovini, Sarajevo, 1965.

3. DJIKIC S., JOVANCEVIC M., Principi i perspektive unapredjivanja proPANOV A.: izvodnje Šumskog sjemena u Bosni i Hercegovini, Sarajevo, 1965.

4. MATIC, V.: 0 planiranjima i o snimanjima uokviru u-

5. KAPETANOVIC N.: Orijentacija samostalnog premjera, Sarajevo, 1966 .

6. TERZIC D.: Proučavanje hemijskog sastava zelenila šmskog drveća - sirovine za proizvodnju koncentrata stočne hrane, Sarajevo, 1970.

7. MATC $V$, DRINIC $P$, STE- Stanje Suma u SR Bosni i Hercegovini preFANOVIC $V$. i CIRIC M.: ma inventuri šuma na velikim površinama $u$ 1964-1968. godini. Sarajevo, 1971.

* Sumarski fakultet u Sarajevu izdaje redovnu periodičnu ediciju "Radovi Sumarskog fakulteta u Sarajevu". U toj ediciji objavljuju se naućni radovi nastavnog osobTja sumarskog fakulteta (od ovogbrojabez Instituta za sumarstvo). Osim "Radova ..." povremeno se publikuju i "Posebna izdanja" u kojima se 5 tampaju strueni radovi i rezultati naućnit istrazivanja namjenjenih praksi Do sada je, ukljucujuci iovu knjiqu, publikovano 15 knjiga "Posebnih izdanja". Naslovi tih knjiga i godine izdavanja navedeni su u ovom spisku 
8. CIRIC M., STEFANOVIC $V$. , DRINIC P.:

9. TERZIC D.:

10. GEORGIJEVIC E., LUTERSEK D., GAVRILOVIC D., i JAREBICA M.:

11. STEFANOVIC V., BURLICA $C$., DIZDAREVIC H., FABI JANIC B., I PROLIC N.:

12. MATIC $V .:$

13. DRINIC P., MATIC V., PAVLIC J.'PROLIC N., STOJANOVIC O.. VUKMIRO. VIC $V$, :
Tipovi bukovih కuma imješovitih కuma bukve, jele i smrçe u Bosni i Hercegovini.Sarajevo, 1971.

Proučavanje hemijskog sastava zeienila sumskog drveca - sirovine za proizvodnju koncentrata stočne hrane, Sarajevo, 1973.

Prilog poznavanju entomofaune suma Bosne $i$ Hercegovine, Sarajevo, 1976.

Tipovi niskih degradiranih šuma submediranskog podruija Hercegovine, Sarajevo. 1977.

Metodika izrade sumskoprivrednih osnova za Šume $u$ drustvenoj svojini na području SR BiH, Sarajevo, 1977.

Tablice taksacionih elemenata visokih i izdanackih suma u SR Bosni i Hercegovini, Sarajevo, 1980.

14. STEFANOVIC $V$., MILANOVIC Ekotipovi bijelog bora (Pinus silvestris S., MEDJEDOVIC S., PINTA- L.) u Bosni. Sarajevo, 1980.

RIC K., RONCEVIC B. I SISCJEVIC D. :

15. STEFANOVIC $V$., BEUS $V .$, Tipovi suma smrče i bijelog bora, jele $i$ BOZALO G., PAVLIC J., VU- smrče, smrce u Bosni. Sarajevo, 1983. KOREP 1.: 


\section{ITUTSTVO SARAONTCIMA}

Casopis "Radovi Sumarskog fakulteta u Sarajevu" objavl juju rezultate istrazivanja saradnika Fakulteta, a izuzetno i drugih naucnih radnika i stručnjaka. Izlazi kao redovna periodicna edicija "posebna izdanja" u kojoj se stampaju razultati istrazivanja namijenjeni praksi.

Rukopisi se predaju Komisiji za izdavacku djelatnost Sumarskog fakulteta putem Sekretarijata Fakulteta $i$ uz odluku organa upravljanja o obezbjedjenom finansiranju. Oni moraju biti posebno pripremljeni za stampu, sto znaci da su uredno otkucani na pisacoj maśsini u dva primjerka $s$ proredom is vidno izdvojenim naslovima poglavlja i potpoglavlja na papiru formata A4.

Svaki rukopis obavezno sadrzi sljedece di jelove: abstrakt, uvod $i$ problem istrativanja, primijenjeni metod, rezultate istrazivanja s diskusijom, zaključke, rezime rada na jednom ili vise svjetskih jezika, spisak koristene literature i sadrzaj rada.

abstrakt sadrzi sljedece podatke: prezime i pocetno slovo imena autora, godinu izdavanja (u zagradi), naziv rada, podatke o svesci, stranu (od-do) i kratak sadrźaj rada na stranom jeziku.

Eventualni graficki prilozi (crtezi, grafikoni i dr.) moraju biti izradjeni tušem na paus papiru formata prilagodjenog odnosu dimenzija kucane strane ili odnosu njene polovine. Fotografije moraju biti jasne i kontrastne, te vezane za tekst.

Imena autora pisu se verzalom ili kurentom sa proredom, u originalu jezika, s godinom izdanja rada u zagradi. Ukoliko se citira rad koji ima više od dva autora, u tekstu se pominje samo prvi autor, sa dodatkom "et al.". Ako se navodi autor $s$ viśe radova iz iste godine onda se, uz radove, dodaju abecedna slova pored godine.

$U$ "literaturi" se radovi navode u originalu jezika, bez numeracije, abecednim redom prezimena autora, $i$ to: prezime $i$ pocetno slovo imena, godina izdanja rada (u zagradi). naziv rada, casopis, broj toma $i$ sveske, stranica (od-do), a kod knjiga jos i mjesto izdavanja. Navode se imena svih autora koristenog rada. Latinski nazivi biljaka i tivotinja moraju biti podvudeni prilikom kucanja.

obim radova moźe iznositi najuise do cetiri autorska tabaka (64 kucane stranice). Za magistarske radove i disertaci je dozvol java se obim do sest autorskih tabaka, odnosno do 100 kucanih stranica. $2 a$ radove koji ce biti objavljeni kao "Posebna izdanja" obim, po pravilu, nije ograničen.

Pored navedenih tehnickih uslova, obavezno jeprilożiti i dvije recenzije rada, a autor je duźan dati pismenu izjavu da rukopis nije predao riti ce predati za stampanje na nekom arugom mjesta. 
